\title{
Beyond Preemption: The Law and Policy of Intellectual Property Licensing
}

\author{
Mark A. Lemley†
}

\section{TABLE OF CONTENTS}

Introduction

I. The Tension Between Article 2B and Intellectual Property.

A. Article 2B's Expansion of the Scope and

Power of Contracts.

B. Potential Conflicts with Intellectual Property Law...................124

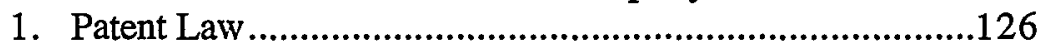

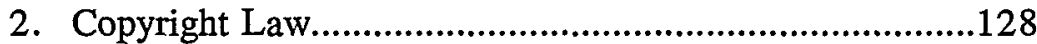

3. Trade Secret Law .......................................................133

4. Trademark Law ..........................................................134

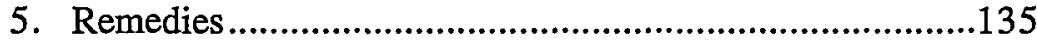

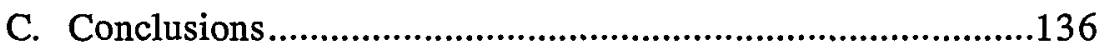

11. Preemption as a Partial Solution................................................136

A. The Nature of 1ntellectual Property Preemption....................137

1. The Basic Nature of Preemption .....................................137

2. Intellectual Property Preemption.......................................138

a. Patent Law ..............................................................138

b. Copyright Law...........................................................139

c. Applying Preemption to Contract Law .......................143

Copyright (C) 1999 Mark A. Lemley and California Law Review, Inc.

$\dagger$ Professor of Law, University of Texas School of Law; Visiting Professor of Law, Boalt Hall School of Law, University of California at Berkeley (Fall 1998); of counsel, Fish \& Richardson P.C., Austin, Texas. I would like to thank Stephen Bamett, Julie Cohen, Richard Craswell, Robert Denicola, Rochelle Cooper Dreyfuss, Paul Goldstein, Robert Gonulkiewicz, Rose Hagan, Paul Heald, Dennis Karjala, Eric Lode, David McGowan, Charles McManis, Rob Merges, Maureen O’Rourke, Malla Pollack, Lloyd Weinreb, and participants in a faculty workshop at Stanford Law School and in the Berkeley Center for Law and Technology's Conference on Article 2B of the Uniform Commercial Code for comments on an earlier draft. I would also like to thank Ryan Garcia and Sherri Shaw for research assistance. 
B. The Limits of Preemption...................................................144

1. Preemption Lacks Nuance ..............................................145

2. Intellectual Property Rules Aren't Always Statutory.........145

3. Intellectual Property Rules Aren't Always Federal ...........146

4. "Contracts Are Different" ............................................147

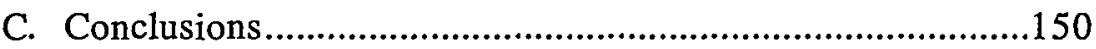

III. Public Policy Restrictions on Information Contracts....................151

A. Copyright Misuse .................................................................151

B. Licensing Contracts as Creatures of Federal Law ....................158

C. State Public Policy Limits on Intellectual Property

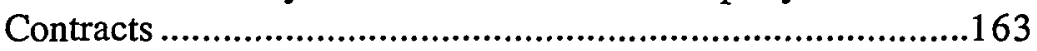

D. The Interaction of Public Policy and Article 2B ...................167

1. Doctrinal Questions ....................................................167

2. Normative Questions................................................169

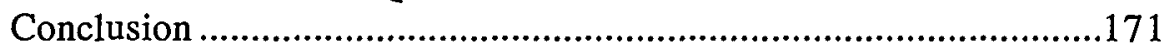




\title{
Beyond Preemption: The Law and Policy of Intellectual Property Licensing
}

\author{
Mark A. Lemley
}

Proposed Uniform Commercial Code Article 2B, which would govern transactions in information, would remake the law of intellectual property licensing in a radical way. But federal and state intellectual property laws and policies impose significant limits on the ability of states to change the rules of intellectual property licensing by contract law. One such limit is preemption, but preemption is unlikely to provide significant protection for the established rules of intellectual property law. Several other doctrines will limit the ability of parties to set their terms by contract, even in the Article $2 B$ world. The first is copyright misuse, which has been applied against restrictive licensing provisions. The second set of doctrines provides that a number of licensing rules are decided as questions of federal, not state, law. The third set of doctrines is a number of state public policies that cannot be overridden by contract. Taken together, these doctrines create a patchwork public policy of intellectual property law that Article $2 B$ cannot alter.

[L]egislatures, courts, and scholars must consider . . . copyright and patent "misuse," and such other issues as federal preemption of state law affecting intellectual property-together with U.C.C. issues if they are to construct a coherent body of transactional rules.

$$
\text { -Robert Merges }{ }^{1}
$$

As contract and encryption begin to displace copyright ... it would surely benefit us all if lawmakers took care to apply to these two substitutes the historical norms of copyright ....

-Paul Goldstein ${ }^{2}$

1. Robert P. Merges, Intellectual Property and the Costs of Commercial Exchange: A Review Essay, 93 Mich. L. REv. 1570, 1571-72 (1995).

2. Paul Goldstein, Copyright and Its Substitutes, 1997 WIs. L. REv. 865, 871. 


\section{INTRODUCTION}

Proposed Uniform Commercial Code Article 2B (Article 2B) ${ }^{3}$ would remake the law of software and intellectual property licensing in a radical way. Sonie of the niore dramatic changes are apparent, at least to those who have invested the time in reading the rapid succession of 200-plus page drafts. ${ }^{4}$ But lurking behind the changes Article $2 \mathrm{~B}$ would impose on the state law of transactions in information is another, more fundamental, shift that is larger than the debate over Article $2 \mathrm{~B}$ itself. Article $2 \mathrm{~B}$ creates a fundamental conflict between the goals of federal and state intellectual property law and the contract law that will govern intellectual property licenses. Under an Article $2 \mathrm{~B}$ regime, litigation won't be about what the parties agreed to do with intellectual property. It won't even be about the scope or limits of intellectual property law itself. Rather, litigation will be about the limits that intellectual property law and policy inipose on state enforcenient of contracts that contravene, distort, or ignore that law. To paraphrase Whit Diffie, it will be

3. U.C.C. art. 2B (Draft, Aug. 1, 1998). Throughout this Article, I will refer to the August I, 1998 Draft of Uniform Commercial Code Article 2B as "Article 2B," with or without the "August Draft" or "draft" designation. References to other versions of the draft will so be noted. The reader should be aware that the draft is a moving target, and should not rely on this Article to identify changes to the draft made after August 1,1998 . The most recent version of the draft can be downloaded fron $<$ http://www.lawlib.uh.edu/ucc2b/>.

4. A few of these changes are discussed infra notes 12-32 and accompanying text. For othcr changes, the reader is referred to the other Articles in this Symposium, as well as those containcd in a companion issue of the Berkeley Technology Law Journal, especially Pcter A. Alces, W(h)ither Warranty: The B(l)oom of Products Liability Theory in Cases of Deficient Software Design, 87 CALIF. L. Rev. 269 (1999) (discussing changes in warranty rules); Julie E. Cohen, Copyright and the Jurisprudence of Self-Help, 13 BERKELEY TECH. L.J. (forthcoming Dec. 1998) (discussing changes in extra-judicial self-help); Rochelle Cooper Dreyfuss, Do You Want to Know a Trade Secret? How Article 2B Will Make Licensing Trade Secrets Easier (But Innovation More Difficult), 87 CAL1F. L. REv. 191, 200-38 (1999) (discussing changes in trade secret law); Jane C. Ginsburg, Authors as "Licensors" of "Informational Rights" Under UCC Article 2B, 13 BERKELEY TECH. L.J. (forthcoming Dec. 1998) (discussing changes in copyright provisions affecting authors). For an overview of thc changes that Article 2B would involve, see J. Thomas Warlick, IV, A Wolf in Sheep's Clothing? Information Licensing and De Facto Copyright Legislation in UCC 2B, 45 J. COPYRIGHT SOC'Y (USA) 158 (1997).

Some commentators assert that Article 2B is not "remaking" anything but is simply codifying existing law. See Robert W. Gomulkiewicz, The License Is The Product: Comments on the Promise of UCC Article $2 B$ for Software Licensing, 13 BERKELEY TECH. L.J. (forthcoming Dec. 1998) (manuscript at 1, on file with author) ("UCC Article 2B is not new law; it broadly accords with the law that is practiced today in the information and software industries."). But even Ray Nimmer, Article 2B's drafter, has apparently abandoned the pretense that the goal of Article 2B is to codify or restate existing law. Instead, Nimmer now promotes the draft as properly embracing change-at lcast change that "expand[s] the role of contracting." Raymond T. Nimmer, Breaking Barriers: The Relation Between Contract and Intellectual Property Law, 13 BERKELEY TECH. LJ. (forthcoming Dec. 1998) (manuscript at 1 , on file with author); $c$. Jessica Litnan, The Tales That Article $2 B$ Tells About Its Connection with Copyright, 13 BERKELEY TECH. LJ. (forthcoining Dcc. 1998) (manuscript at 16 , on file with author) (noting Article 2B's schizophrenia regarding its relationship to existing law). 
about the transformation of copyright law from a creator's rights statute to a consumer protection statute. ${ }^{5}$

The most obvious way im which these limits will be tested is through federal preemption, either of particular provisions of state contract law or of particular contract terms enforced by state courts. A number of commentators have discussed the nature and limits of intellectual property preemption, both im general ${ }^{6}$ and in the specific context of state contract terms. ${ }^{7}$ Indeed, some of the contributions to this Symposium address precisely this subject. ${ }^{8}$ What one can discern from this scholarship is that there are several different approaches to federal intellectual property preemption, and that the law of preemption is a mess. ${ }^{9}$

I want to suggest something a little different. In this Article, I argue that the influence of intellectual property law and policy on contract enforcement is not solely a function of the complex and arcane rules of

5. See Whit Diffie, Address at the American Committee for Interoperable Systems Meeting (Feb. 18, 1998). Glynn Lunney has made a similar point. See Glynn Lunney, Protecting Digital Works: Copyright or Contract? (1998) (unpublished manuscript at 3-4, on file with author) ("For preemption to become not only a part of copyright, but in some sense the central part, would require a radical reconception of copyright. We would have to view copyright, not as a means for providing protection, but as a means for limiting the protection permitted.").

Jane Ginsburg has objected to this development, and indeed charged that the entire concept of "user rights" in copyright is loaded and largely undesirable. See Jane C. Gimsburg, Authors and Users in Copyright, 45 J. Copyright Soc'Y (USA) 1, 2-3 (1997). Ginsburg inakes her argument in part by redefining "user rights" to include only rights to make superseding and not transformative copies. See id. at 3-4. I think that this distinction is unreasonable because it seems both to restrict the concept of "users" of copyrighted works to only the subclass of consumers and to ignore the wholesale elimination of consumer and improver rights that is occurring across the board in copyright today.

6. See, e.g., Howard B. Abrams, Copyright, Misappropriation, and Preemption: Constitutional and Statutory Limits of State Law Protection, 1983 SuP. CT. REv. 509; Paul Goldstein, Kewanee Oil Co. v. Bicron Corp: Notes on a Closing Circle, 1974 SuP. Cr. Rev. 81; Paul Heald, Federal Intellectual Property Law and the Economics of Preemption, 76 IowA L. REv. 959 (1991) [hereinafter Heald, Economics]; John Shepard Wiley, Jr., Bonito Boats: Uninformed but Mandatory Federal Preemption Policy, 1989 Sup. CT. Rev. 283; Paul Heald, Comment, Unfair Competition and Federal Law: Constitutional Restrictions on the Scope of State Law, 54 U. CHI. L. Rev. 1411 (1987) [hereinafter Heald, Unfair Competition].

7. See, e.g., Dennis S. Karjala, Federal Preemption of Shrinkwrap and On-Line Licenses, 22 U. Dayton L. Rev. 511 (1997); Ramona L. Paetzold, Contracts Enlarging a Copyright Owner's Rights: A Framework for Determining Unenforceability, 68 NEB. L. Rev. 816 (1989); David A. Rice, Public Goods, Private Contract, and Public Policy: Federal Preemption of Sofnvare License Prohibitions Against Reverse Engineering, 53 U. PITT. L. Rev. 543, 602-04 (1992).

8. See David Nimmer et al., The Metamorphosis of Contract into Expand, 87 Calif. L. Rev. 17, 40-76 (1999); see also J.H. Reichman \& Jonathan A. Franklin, Privately Legislated Intellectual Property Rights: The Limits of Article 2B of the U.C.C., Address Before the Berkeley Center for Law \& Technology's Conference, Intellectual Property and Contract Law for the Information Age: The Impact of Article 2B of the Uniform Commercial Code on the Future of Information and Commerce (Apr. 24, 1998).

9. Maureen O'Rourke has made a similar point. See Maureen A. O'Rourke, Copyright Preemption After the ProCD Case: A Market-Based Approach, 12 BERKELEY TECH. L.J. 53, 76 (1997) ("The confusion and inconsistency of preemption law makes preemption issues notoriously difficult to resolve."). But see Heald, Economics, supra note 6, at 959 (finding consistent themes in intellectual property preemption decisions). 
federal preemption. Three more nuanced doctrines can also influence contract enforcement: (1) copyright misuse; (2) federal public policy that requires resolution of at least some intellectual property questions on intellectual property rather than contract terms; and (3) similar mandatory rules of state imtellectual property law. These public policy limits certainly won't prevent the enforcement of all license terms, or even of all terms that conflict with contract law. But they will bar some license terms that Article $2 \mathrm{~B}$ purports to validate. And even if Article $2 \mathrm{~B}$ isn't adopted, these limits will play an important role in regulating the growth of contract law.

In Part I, I briefly explain why the potential for conflict between contract and intellectual property law arises at all. In Part II, I suggest that while preemption has an important role to play in resolving this conflict, it will not and cannot solve the problem alone. Finally, in Part III, I examine court decisions that have applied "public policy" rationales to reject or avoid enforcing objectionable contract terms. I also offer some thoughts on how some key Article $2 \mathrm{~B}$ provisions will fare under such public policy tests. Specifically, I suggest that even if Article $2 \mathrm{~B}$ is adopted, its effect on intellectual property licensing will be limited by the existence of numerous rules from outside contract law.

Before I begm, a word about my methodology is in order. My goal in this Article is largely descriptive and predictive, rather than normative. Elsewhere, I have argued that there is good reason to be skeptical about the expansionist vision of contract law as a supplement to the power of intellectual property owners. ${ }^{10}$ Most other commentators have taken a similar position. " But whether one thinks that the changes wrought by Article 2B are good or bad, we will have to confront the difficult task of drawing a line between conflicting aspects of intellectual property policy and contract law. I am not arguing (here) for the creation of a new public policy exception to state contract law for cases in which contract law touches on matters of intellectual property concern.

10. See Mark A. Lemley, The Economics of Improvement in Intellectual Property Law, 75 Tex. L. REv. 989, 1048-72 (1997) [hereinafter Lemley, Economics of Improvement]; Mark A. Lemley, Romantic Authorship and the Rhetoric of Property, 75 Tex. L. REv. 873, 900-03 (1997) [hereinafter Lemley, Romantic Authorship]; Mark A. Lemley, Intellectual Property and Shrinkwrap Licenses, 68 S. CAL. L. REv. 1239, 1274-92 (1995) [hereinafter Lemley, Shrinkwrap Licenses].

11. See, e.g., Julie E. Cohen, Lochner in Cyberspace: The New Economic Orthodoxy of Rights Management, 97 MicH. L. REv. (forthcoming 1998); Niva Elkin-Koren, Contracts in Cyberspace: Rights Without Lavs, 73 CHI.-KENT L. REv. (forthcoming 1998) [hereinafter ElkinKoren, Contracts in Cyberspace]; Niva Elkin-Koren, Copyright Policy and the Limits of Freedom of Contract, 12 BeRKeley TeCH. L.J. 93, 106-13 (1997) [hereinafter Elkin-Koren, Copyright Policy]; Karjala, supra note 7, at 519-20; Jessica Litman, Revising Copyright Lav for the Information Age, 75 OR. L. REv. 19, 25-30 (1996); Rice, supra note 7, at 561-67. For a contrary view, sce Tom W. Bell, Fair Use vs. Fared Use: The Impact of Automated Rights Management on Copyright's Fair Use Doctrine, 76 N.C. L. Rev. 557, 592 (1998); Trotter Hardy, Property (and Copyright) in Cyberspace, 1996 U. ChI. Legal F. 217, 228. 
Rather, I am suggesting that the public policy jurisprudence already exists, and we can only understand Article $2 \mathrm{~B}$ in its context.

\section{The Tension Between Article 2B and Intellectual Property}

Article $2 \mathrm{~B}$ is a big document, and as the papers in this Symposium demonstrate, its interaction with intellectual property law is complex. ${ }^{12}$ While Article $2 \mathrm{~B}$ does many unobjectionable things - and even some good things ${ }^{13}$ - that have nothing to do with intellectual property law, the critical thing about Article $2 \mathrm{~B}$ for my purposes is its dramatic expansion of the scope and power of contracts, particularly contracts drafted by software vendors and intellectual property owners. This expansion leads to potential conflicts and tensions between Article 2B and intellectual property law. In this Part, I discuss the ways in which Article 2B expands the scope and power of contracts, as well as the conflicts with intellectual property law that this expansion may create.

12. Merely parsing the scope provisions of Article $2 B$ is worthy of one or more papers unto itself. As near as I can determine from the August Draft, the provisions of Article 2B apply to all "licenses" of information and all software and access contracts, unless specifically excluded. See U.C.C. § 2B-103(a)(1) (Draft, Aug. 1, 1998). A license is defined broadly to mean virtually any express contract relating to information unless it is an unconditional transfer of ownership of informational property rights. See id. § 2B-102(a)(28). Indeed, a transaction is a "license"-and therefore within the scope of Article 2B-even if it transfers title to a copy, so long as the transaction itself "expressly grants less than all informational rights in the information." Id. This means that virtually every possible transaction in information is a "license," even those that everyone would agree are sales of goods under current law. Indeed, it would appear impossible to sell a book under the literal language of this provision. While the reporter's note 26 to section $2 \mathrm{~B}-102$ states that the term "license" "does not include a sale of a copy of a book since there is no express contractual restriction on the use of the information," id. § $2 \mathrm{~B}-102$ reporter's note 26 , this reflects a imsunderstanding about intellectual property law. A sale of a book does not grant the buyer ownership of the copyright in the book, and books typically make that clear on the copyright page. A sale of a book is, therefore, within the literal definition of a "license."

Transactions involving copyrights, trade secrets, and the right of publicity are certainly within the scope of Article 2B. Tradeinarks and patents appear at first to be excluded from coverage, see id. $\S$ 2B-104(2), but we are then told that they will be mcluded if "associated with a license or software contract that is otherwise covered by this article....," id. Since under the defimition of a "license" any transaction in information is almost certainly included, at the very least, software patents, and arguably a much broader group of patents, also fall within Article 2B.

What constitutes software, and which patents are "software patents," is itself far from clear. See Michele C. Kane, When Is a Computer Program Not a Computer Program?, 13 BeRKeley TECH. LJ. (forthcoming Dec. 1998) (manuscript at 1 , on file with author).

13. Chief among the good aspects of Article $2 B$ is its establishment of uniform rules regarding on-line and electronic contracting. This may truly be an area where having a uriform rule matters more than what the rule actually says. $C f$. Peter A. Alces \& Harold F. See, The Commercial, LAW OF INTELLECTUAL, Property 346-47 (1994) (noting the importance of certainty in commercial law). But see A. Michael Froomkin, $2 B$ as Legal Software for Electronic Contracting: Operating System or Trojan Horse, 13 BERKELEY TECH. LJ. (forthcoming Dec. 1998) (challenging the Article 2B framework for digital siguatures). 


\section{A. Article 2B's Expansion of the Scope and Power of Contracts}

Article 2B expands the scope and power of contracts in three ways. ${ }^{14}$ First, Article $2 \mathrm{~B}$ reverses the well-settled rule of existing law that in determining whether a transaction is a sale, a lease, or a license, courts look to the economic realities of the exchange. ${ }^{15}$ Under Article 2B, a

14. Article 2B has claimed a posture of "aggressive neutrality" with respect to federal intellectual property law. See U.C.C. art. 2B Preface at 48 (Draft, Feb. 1998); see also U.C.C. art. 2B Preface at 33 (Draft, Apr. 1998) ("This Article does not concern, and does not alter any law creating or limiting intellectual property rights or privileges in information."). In fact, however, a change in the terms of contract law necessarily will affect the contract-intellectual property interface. Such a change cannot be considered "neutral" in application, even if it is neutral in intent, because the balance of rights between vendors and users is necessarily a function of all the legal rules that apply to them. Further, the draft concedes that it is not always neutral even in intent: "[I]n several situations, provisions push against explicit federal rules insofar as reasonably possible." U.C.C. art. 2B Preface (Draft, Aug. 1, 1998).

The preference of the drafters for some federal rules and not others might be discerned in the rather schizophrenic approach Article 2B takes toward preeinption. On the one hand, Article 2B asserts that state law should be made consistent with federal law, because to do otherwise would be to "create[] true traps for the unwary." Id. On the other hand, the same page of the draft rejects any effort to inject other federal principles into the debate, claiming "neutrality," see id., despite instruction by both the American Law Institute (ALI) and the National Conference of Commissioners on Uniform State Laws (NCCUSL) to take account of those federal policies. See Charles R. McMamis, The Privatization (or "Shrink-Wrapping") of American Copyright Law, 87 CaLIF. L. Rev. 173 (1999) (discussing the ALI instruction); Electronic Mail from Harvey Perlman, Nebraska Commissioner on Uniform State Laws, NCCUSL, to Rochelle Cooper Dreyfuss (Sept. 22, 1998) (on file with California Law Review) (discussing NCCUSL instruction).

Contrast this approach with Article 9 of the Uniform Commercial Code (U.C.C.), which contains "stepback" provisions for cases in which its provisions on security interests overlap with federal law, including federal imtellectual property law. See U.C.C. $\$ \S 9-104,9-302$ (1994). For a discussion of inconsistencies in the Article 9 approach, see Alice Haemmerli, Insecurity Interests: Where Intellectual Property and Commercial Law Collide, 96 CoLum. L. Rev. 1645 (1996).

15. In the context of traditional nrass-market transactions for software, the totality of the circumstances surrounding the transaction strongly suggests that the transaction is in fact a sale rather than a license. There is no bargaining over license terms. The purchaser (licensec?) commonly obtains a single copy of the software, along with docuinentation, in a box at a retail software store. The box contains a single price, which the purchaser pays up front, and which constitutes the entire payment for the "license." The purchaser also pays sales tax on the "license." The license does not run for a definite term and need not be renewed, but is perpetual unless terminated by the vendor (something that almost never occurs).

In light of these indicia, and because nrost purchasers think they are "buying" a physical copy of a program, almost all courts and commentators that have considered the issue have concluded that a shrinkwrap license transaction is a sale of goods rather than a license, and that it is therefore covercd by Article 2 of the current U.C.C. See, e.g., In re Dak Indus., Inc., 66 F.3d 1091, 1094 (9th Cir. 1995); Step-Saver Data Sys. v. Wyse Tech., 939 F.2d 91, 99-100 (3d Cir. 1991); Advent Sys. Ltd. v. Unisys Corp., 925 F.2d 670, 675-76 (3d Cir. 1991); RRX Indus., Inc. v. Lab-Con, Inc., 772 F.2d 543, 546 (9th Cir. 1985); Synergistic Techs., Inc. v. IDB Mobile Communications, Inc., 871 F. Supp. 24, 29 (D.C. 1994); Arizona Retail Sys. Inc. v. Software Link, Inc., 831 F. Supp. 759, 762 (D. Ariz. 1993); Hospital Computer Sys. Inc. v. Staten Island Hosp., 788 F. Supp. 1351, 1360 (D.N.J. 1992); In re Anica, Inc., 135 B.R. 534, 552-53 (Bankr. N.D. Ill. 1992); Neilson Bus. Equip. Ctr. 1nc. v. 1talo V. Montelcone, 524 A.2d 1172, 1174-75 (Del. 1987); Photo Copy, Inc. v. Software, Inc., 510 So. 2d 1337, 1338-39 (La. Ct. App. 1987); USM Corp. v. Arthur D. Little Sys. Inc., 546 N.E.2d 888 (Mass. App. Ct. 1989); Dreier Co., Inc. v. Unitronix Corp., 527 A.2d 875, 879 (N.J. Super. Ct. App. Div. 1986); Schroders, Inc. v. Hogan Sys., Inc., 522 N.Y.S.2d 404, 405-06 (Sup. Ct. 1987); Communications Groups, Ine. v. 
transaction is automatically a license unless it constitutes an assignment of the intellectual property right itself. ${ }^{16}$ And if it is a license, Article $2 \mathrm{~B}$ applies. ${ }^{17}$ Article 2B thus creates a new meaning of "licensing" information. This ineaning is unknown to copyright or patent law, and encompasses transactions that intellectual property has always dealt with as sales. ${ }^{18}$

Second, Article $2 \mathrm{~B}$ redefines what constitutes a contract, abandoning the focus on offer and acceptance, and therefore on the agreeinent at the time the parties conclude a deal, in favor of a rule that the

Warner Communications Inc., 527 N.Y.S.2d 341, 343-44 (Civ. Ct. 1988); Lemley, Shrinkwrap Licenses, supra note 10, at 1244 n.23; Bonna Lynn Horovitz, Note, Computer Software as a Good Under the Uniform Commercial Code: Taking a Byte Out of the Intangibility Myth, 65 B.U. L. Rev. 129 (1985); cf. Applied Info. Management, Inc. v. Icart, 976 F. Supp. 149, 155 (E.D.N.Y. 1997) (finding that whether a transaction denominated a "license" was in fact a sale conveying ownership was a disputed question of fact). But see Microsoft Corp. v. Harmony Computers \& Elecs., Inc., 846 F. Supp. 208, 212 (E.D.N.Y. 1994) (assuming without analysis that a mass-market transaction was a license rather than a sale).

Of course, the economic realities of a transaction may change over time. On-line distribution looks less like a traditional sale of goods than does distribution through a store or mail order catalog; this could change the analysis under existing law. Cf. Joel Rothstein Wolfson, Information Transactions on the Information Superhighway: It's Not Just Software Law Anymore, $6 \mathrm{~J}$. PROPRIETARY RTs. 1, 3-5 (1994) (arguing that on-line contracts have fewer enforcement problenis than real-world contracts). And some on-line transmission schemes look unore like performances than the distribution of copies, though of course they may be both. Cf. Mark A. Lemley, Dealing with Overlapping Copyrights on the Internet, 22 U. DAYTON L. REv. 547, 550-62 (1997) [hereinafter Lemley, Overlapping Copyrights] (arguing that Internet transmission is a copy, a distribution, and a public performance).

16. The defimition of a license is,

[A] contract that authorizes access to or use of information or of informational rights and expressly limits the contractual rights or permissions granted... or expressly grants less than all informational rights in the information. A contract may be a license... whether or not the contract transfers title to a copy.

U.C.C. $\$ 2 B-102(28)$ (Draft, Aug. 1, 1998). Since the intellectual property owner has effective control over the terms of the "contract," see infra notes 19-32 and accompanying text, this means that so long as the intellectual property owner transfers less than her complete ownership interest in the information, the transaction will be deemed a license. For a discussion of this important shift im approach, see David A. Rice, Digital Information As Property and Product: U.C.C. Article 2B, 22 U. DAYton L. REv. 621 (1997); cf. Lunney, supra note 5, at 5 (arguing that "the word 'license' is simply inaccurate" in this context).

17. See U.C.C. § 2B-103(a)(1) (Draft, Aug. 1, 1998). The drafters assure us that consumers shouldn't be worried about this because " $t$ t]he end user is often benefited by a license rather than a sale transaction." Id. § 2B-208, reporter's note 5(a). This is a bit disingenuous. Sales convey a number of rights to users under federal intellectual property law; they may exhaust some of the seller's rights with respect to the intellectual property enbodied in the product sold. See 17 U.S.C. \$ 109(a) (1994). Licenses typically purport to do no such thing. Even the examples cited by reporter's note 5(a) in support of the proposition that licenses benefit consumers suggest exactly the oppositethey merely indicate that licensors may be willing to give away some part of what federal law would require them to were the transaction a sale.

18. See Nimmer et al., supra note 8, at 34-40 (discussing this shift); Reichman \& Franklin, supra note 8 , at 49 (same). Article 2B's drafter Ray Nimmer has elsewhere poimted out the critical distinction between sale and license for copyright purposes. See Raymond T. Nimmer, Article 2B: An Introduction, 16 J. MARShall J. COMPUTER \& INFO. L. 211, 218-19 (1997). 
intellectual property owner's standard form terms will be enforced, even if they are contained in a "shrinkwrap" or "clickwrap" license that the buyer cannot see until the transaction has already occurred. ${ }^{19}$ In so doing, Article $2 \mathrm{~B}$ adopts a view that is decidedly in the minority among current courts, ${ }^{20}$ and that is dramatically to the benefit of the drafters of

19. Article $2 \mathrm{~B}$ provides that terms are considered part of a contract if the buyer "manifest[s] assent." U.C.C. \& 2B-208(a) (Draft, Aug. 1, 1998). This phrase is broad enough to include engaging in the "affirmative conduct" of using the information one has already bought, if the shrinkwrap license so provides. See id. § 2B-111(c); id. § 2B-111 reporter's note 3 . Indeed, no person need be involved at all in the assent process. See id. $\S 2 \mathrm{~B}-111$ (c); id. reporter's note 5 . The reporter's notes to Article $2 \mathrm{~B}$ section $2 \mathrm{~B}-111$ also provide that contract terms can be included even without a manifestation of assent, simply by giving prior notice to the other party of the terms. See id. $\S 2 \mathrm{~B}-111$ reporter's note 6 . This too represents a change from current law. See, e.g., Authors \& Newspapers Ass'n v. O'Gorman Co., 147 F. 616, 619-20 (D.R.I. 1906) (holding that merely including "license" terms on the inside cover of a book did not create a contract on those terms).

By contrast, in some on-line "clickwrap" licenses, the buyer can see the license terms before entering into the contract. Such licenses are more likely to be enforceable under traditional contract doctrine. See, e.g., Hotmail Corp. v. Van Money Pie Inc., 47 U.S.P.Q.2d 1020 (N.D. Cal. 1998).

20. Numerous courts have rejected shrinkwrap licenses as unenforceable. See Step-Saver Data Sys. v. Wyse Tech., 939 F.2d 91, 98-100 (3d Cir. 1991); Vault Corp. v. Quaid Software Ltd., 847 F.2d 255, 270 (5th Cir. 1988); Novell, Inc. v. Network Trade Ctr., Inc., No. 95 Cv00523 (D. Utah 1997); Morgan Labs., Inc. v. Micro Data Base Sys., Inc. 41 U.S.P.Q.2d 1850 (N.D. Cal. 1997) (refusing to allow a shrinkwrap license to modify a prcexisting contract); Arizona Retail Sys., Inc. v. The Software Link, Inc., 831 F. Supp. 759, 764-66 (D. Ariz. 1993); Foresight Resources Corp. v. Pfortmiller, 719 F. Supp. 1006, 1010 (D. Kan. 1989); see also L. RAY PATTERSON \& STANLEY W. LiNDBERG, The NATURE OF COPYRIGHT 220 (1991) (concluding that shrinkwrap licenses arc almost certainly unenforceable); Lemley, Shrinkwrap Licenses, supra note 10, at 1248-59 (discussing these cases); cf. Microstar v. Formgen, Inc., 942 F. Supp. 1312, 1317 (S.D. Cal. 1996) (noting but not resolving the issue), aff'd in part, rev'd in part on other grounds, 1998 WL 598544 (9th Cir. Sept. 11, 1998). While these decisions were rendered on various grounds, a typical conclusion is that the contract was formed when the software was exchanged for money, and that the terms of the contract do not include a shrinkwrap license that was only brought to the attention of the buyer after the exchange. See Step-Saver, 939 F.2d at 98-100.

The Seventh Circuit is the only court to have enforced a shrinkwrap license. See ProCD, Inc. v. Zeidenberg, 86 F.3d 1447, 1449 (7th Cir. 1996); cf. Hill v. Gateway 2000, Inc., 105 F.3d 1147, 1150 (7th Cir. 1997) (extending ProCD in a non-shrinkwrap case), cert. denied, 118 S. Ct. 47 (1997). The Hill decision is a sufficiently radical departure from traditional principles of contract formation that every Article 2B draft until the present one rejected it. See U.C.C. $\$ 2 B-111$ (b) (Draft, Apr. 1998) ("[M]ere retention of a record without objection is not a manifestation of assent."). Section 111(b) was removed from the current draft, a significant further change in governing law outside the Seventh Circuit.

Lunney contrasts Hill with Authors \& Newspapers Ass'n v. O'Gorman Co., 147 F. at 619-20, in which the court rejected an attempt to impose contractual terms on the sale of a copyrighted book by placing those terms on the inside cover. See Lunney, supra note 5. The Authors \& Newspapers court noted that "affirmative proof of communication, additional to that afforded by the mere fact that a notice is in the book, is essential to show that the purchaser agrced." Authors \& Newspapers, 147 F. at 619; see also Lunney, supra note 5, at 7 (endorsing this result).

For criticism of ProCD on contract law grounds, see, e.g., Michael J. Madison, "Legal Ware": Contract and Copyright in the Digital Age, 67 FordHAM L REv. (forthcoming 1999); Apik Minassian, The Death of Copyright: Enforceability of Shrinkwrap Licensing Agreements, 45 UCLA L. Rev. 569 (1997); Jason Kuchmay, Note, ProCD, Inc. v. Zeidenberg: Section 301 Copyright Preemption of Shrinkwrap Licenses-A Real Bargain for Consumers?, 29 U. ToL. L. REv. 117 (1997); Kell Corrigan Mercer, Note, Consumer Shrink-Wrap Licenses and Public Domain Materials: Copyright Preemption and Uniform Commercial Code Validity in ProCD v. Zeidenbcrg, 30 
standard forms, who will not even need a signature (or its electronic equivalent) in order to enforce their terms. ${ }^{21}$ Because of this shift, contracts under Article $2 \mathrm{~B}$ are really more akin to property rights: the contracts can be viewed as equitable servitudes that "run with" the goods in much the same way that some property owners once tried to impose restrictions on chattel. ${ }^{22}$ This shift is extremely important. The existing relationship between intellectual property and contract law is

Creighton L. Rev. 1287 (1997); Robert J. Morrill, Comment, Contract Formation and the Shrink Wrap License: A Case Comment on ProCD, Inc. v. Zeidenberg, 32 New ENg. L. Rev. 513, 537-50 (1998); Christopher L. Pitet, Comment, The Problem With "Money Now, Terms Later": ProCD, Inc. v. Zeidenberg and the Enforceability of "Shrinkwrap" Software Licenses, 31 LoY. L.A. L. REv. 325 (1997); Stephen P. Tarolli, Comment, The Future of Information Commerce Under Contemporary Contract and Copyright Principles, 46 AM. U. L. REv. 1639 (1997); Lunney, supra note 5. For criticism of ProCD on copyright preemption grounds, see Elkin-Koren, Copyright Policy, supra note 11, at 106-13; Karjala, supra note 7, at 521; McManis, supra note 14, at 178-79, 182-84; Minassian, supra, at 569; O'Rourke, supra note 9; Brian Covotta \& Pamela Sergeeff, Comment, ProCD, Inc. v. Zeidenberg, 13 Berkeley TECH. LJ. 35 (1998); Thomas Finkelstem \& Douglas C. Wyatt, Note, Slininkwrap Licenses: Consequences of Breaking the Seal, 71 ST. JoHN's L. REv. 839, 868-69 (1997); Jeannett M. Hill, Note, The State of Copyright Protection for Electronic Databases Beyond ProCD v. Zeidenberg: Are Shrinkwrap Licenses a Viable Alternative for Database Protection?, 31 IND. L. REv. 143, 165-72 (1998); Mercer, supra, at 1287; Tarolli, supra, at 1639; Brett L. Tolman, Note, ProCD, Inc. v. Zeidenberg: The End Does Not Justify the Means in Federal Copyright Analysis, 1998 BYU L. REv. 303; Note, Seventh Circuit Holds That Shrinkwrap Licenses Are Enforceable, 110 HARV. L. REv. 1946 (1997).

For arguments endorsing the result in ProCD, see Michael A. Jaccard, Securing Copyright in Transnational Cyberspace: The Case for Contracting with Potential Infringers, 35 Colum. J. Transnat'l L 619 (1997); Darren C. Baker, Note, ProCD v. Zeidenberg: Commercial Reality, Flexibility in Contract Formation, and Notions of Manifested Assent in the Arena of Shrinkwrap Licenses, 92 Nw. U. L. REv. 379 (1997); Brandon L. Grusd, Note, Contracting Beyond Copyright: ProCD, Inc. v. Zeidenberg, 10 HARv. J.L. \& TECH. 353 (1997); Jerry David Monroe, Comment, ProCD, Inc. v. Zeidenberg: An Emerging Trend in Shrinkwrap Licensing?, 1 MARQ. INTELl. Prop. L Rev. 143 (1997); Joseph C. Wang, Casenote, ProCD, Inc. v. Zeidenberg and Article 2B: Finally, The Validation of Shrink-Wrap Licenses, 16 J. MARShalL J. CoMPuTER \& INFo. L. 439, 442 (1997).

21. Actually, the draft clearly contemplates that only licensors, not licensees, will be able to take advantage of some of these new provisions enforcing standard forms. For example, section 2B208 , dealing with mass-market licenses, is drafted in such a way that it applies only to terms written by licensors that bind licensees. See U.C.C. $\$ 2$ B-208 (Draft, Aug. 1, 1998). Thus, it speaks of parties having "an opportunity to review a mass-market license before becoming obligated to pay for the information," id. § 2B-208(b), and entitlement to receive a refund from the licensor, see id. § 2B208(b)(1). These terms clearly contemplate only licensor-drafted contracts, not licensee-drafted contracts. Transactions outside of the mass market, by contrast, are treated more neutrally. See id. $\S$ 2B-207 (setting forth requirenents for adopting terms of records that are not dependent on the party's status).

22. Some commentators have made this point. See Thomas M.S. Hemnes, Restraints on Alienation, Equitable Servitudes, and the Feudal Nature of Computer Software Licensing, 71 DENV. U. L. REV. 577 (1994) (discussing enforceability of restrictions on software use by reference to the doctrine of equitable servitudes); Margaret Jane Radin \& Polk Wagner, The Myth of Private Ordering: Rediscovering Legal Realism in Cyberspace 73 CHI.-KENT L. REV. (forthcoming 1998); Lunney, supra note 5; $c f$. Stewart E. Sterk, Freedom from Freedom of Contract: The Enduring Value of Servitude Restrictions, 70 IowA L. REv. 615 (1985) (justifynig restrictions on equitable servitudes on the grounds that such servitudes create significant negative externalities). Sterk's point has even greater force for intellectual property than it does for real property. 
based on a conception of what constitutes an enforceable contract. Article 2B changes that conception; as a result, it cannot help but change the relationship as well.

Finally, Article 2B makes virtually all of its default rules subject to change by "agreement of the parties," 23 including its provisions on choice of law, ${ }^{24}$ choice of forum, ${ }^{25}$ the remedies to be awarded, ${ }^{26}$ and the implied warranties of noninfringement, merchantability, and program content. ${ }^{27}$ All of these provisions can be waived by contract. And since Article $2 \mathrm{~B}$ makes it so easy to write and enforce the terms of a contract, a software vendor with a good lawyer can quite easily enforce virtually whatever terms it likes simply by putting them "conspicuously" in a multi-page document that the user cannot even see (much less agree to) until after buying, installing, and beginning to run the software. ${ }^{28}$ There are only a few limitations on a software vendor's power to create whatever terms it likes. ${ }^{29}$ Notably, contract terms that are unconscionable

23. See U.C.C. art. 2B Preface (Draft, Aug. 1, 1998) (stating as a theme of Article 2B that "'the fundamental tenet of the common law [is the] freedom of the parties to contract.'... A default rule applies only if the parties do not agree to the contrary.") (quoting U.C.C. art. 2A).

A recent study by Russell Korobkin has found that people naturally treat default rules as "endowments" and demonstrate an "irrational" preference for retaining them. See Russell Korobkin, The Status Quo Bias and Contract Default Rules, 83 CORNELL L. REv. 608 (1998). If this is right, it may matter what default rules are selected even in the context of a statute like Article $2 \mathrm{~B}$, which seems designed primarily to allow people to avoid them. On the design of default rules, see Ian Ayres \& Robert Gertner, Filling Gaps in Incomplete Contracts: An Economic Theory of Default Rules, 99 YALE L.J. 87 (1989).

24. See U.C.C. § 2B-107(a) (Draft, Aug. 1, 1998).

25. See id. § 2B-108(a).

26. See id. \$ 2B-703(a), (d).

27. See id. $\S \S 2 \mathrm{~B}-401(\mathrm{~d}), 406$.

28. The Augnst Draft is more extreme in this respect than previous drafts. The February Draft endorsed Restatement (Second) of Contracts section 211 (1981), which permits hidden terms to be enforced unless they are "unfair" or "surprising" and would cause most purchasers to rejeet the contract were they aware of the terms. See U.C.C. \& 2B-208, reporter's note 3 (Draft, Feb. 1998). By contrast, the August Draft rejects section 2B-211, concluding that even unfair, surprising, "dealkiller" terms that are hidden inside shrinkwrap licenses may be enforced as long as they are not actually unconscionable. See U.C.C. § 2B-208, reporter's note 1 (Draft, Aug. 1, 1998).

29. Section 2B-106(b) lists twelve rules that cannot be varied by contraet. See id. $\S 2 \mathrm{~B}-106(\mathrm{~b})$. But on closer inspection many of these supposedly mandatory rules turn out to be illusory. For example, section 2B-106 lists as mandatory rules choice of law and choice of forum, see id. § $2 \mathrm{~B}$ $106(b)(1)-(2)$, but both the choiee of law and choice of forum provisions themselves provide that they can be varied by contract, see id. §§ 2B-107(a), 2B-108(a). Similarly, the "mandatory" rules governing diselamier of warranties in section $2 \mathrm{~B}-406$, see $i d$. $\$ 2 \mathrm{~B}-106(\mathrm{a})(9)$, in fact provide that warranties can be disclaimed; they merely set out the means for doing so, see id. $\$ 2 \mathrm{~B}-406$. And perhaps most egregious, section 2B-705(a) - claimed as a mandatory rule governing the statute of limitations, see id. $\S 2 \mathrm{~B}-106(\mathrm{~b})(11)$ - in fact provides that the parties can vary the statute of limitations within a certain range, see id. $\S 2 \mathrm{~B}-705$ (a). A contract provision that did purport to vary a statute of limitations-just what section 2B-705(a) would allow-was held uneonscionable in Angus Medical Co. v. Digital Equipment Corp., 840 P.2d 1024, 1030-31 (Ariz. Ct. App. 1992). In these eases, what is claimed to be a mandatory rule turns out to be a default rule after all.

In other cases, it is not clear whether the rule is mandatory or not. For example, section 2B-704 provides that an excessive liquidated damages clause is "void as a penalty." U.C.C. $\S 2$ B-704(a) 
may not be enforced. ${ }^{30}$ While there were once mandatory rules regarding self-help, most limitations on the licensor's right to use self-help were eliminated in the August Draft. ${ }^{31}$ In short, Article 2B allows those who draft the contract terms to enforce almost any terms they desire. ${ }^{32}$

(Draft, Aug. 1, 1998). Section 2B-106 touts this as a mandatory rule. See id. $\$ 2 \mathrm{~B}-106(\mathrm{~b})(10)$. But section 2B-703 provides that the parties can agree to additional remedies not provided for in the statute. See id. § 2B-703(a). Does section 2B-704(a) impliedly limit section 2B-703(a)? We aren't told; if anything, the language of section 2B-106 imight be read to imply that section 2B-704(a) is not a mandatory rule. See id. $\$ 2 \mathrm{~B}-106(\mathrm{~b})$ ("Except to the extent provided in the following listed sections, the agreement may not vary ... the limitations on liquidated damages ...."); id. § 2B-106(c)(1) ("IT]he use of mandatory language or the absence of a phrase such as 'unless otherwise agreed" in a provision of this article does not preclude the parties from varying the effect of the provision by agreement."); id. § 2B-106(a) ("Except as otherwise expressly provided in this article or in Article $1-102(3)$, the effect of any provision of this article, including allocation of risk or imposition of a burden, may be varied by agreement of the parties.").

Still other instances of the mandatory rules are so obvious that one wonders why they needed to be included at all. For example, section 2B-118 appears to provide that if you didn't order a product, and you return it, you don't have to pay for it, see id. $\S 2 \mathrm{~B}-118$; seetion 2B-626 provides that a licensor has to provide notice before terminating a contract governing information that the licensee owns, see id. $\$ 2 \mathrm{~B}-626$. Perliaps I should be heartened that these are mandatory rules and the parties can't contract around them. In fact, though, I am more concerned that the negative implication of section 2B-106 is that every other provision in Article 2B can be varied by contract. See Joel Rothstein Wolfson, Nine Questions People Always Ask About the Proposed Article $2 B$ of the UCC, J. INTERNET L., April 1998, at 17, 18 (noting that under Article 2B, "you may contract out of virtually any restriction, right or obligation in the statute"). Wolfson refers to the "short list" of mandatory rules as "common sense exclusions." Id.

30. See U.C.C. §§ 2B-1 10, 2B-208(a)(1) (Draft, Aug. 1, 1998).

31. All prior drafts had imposed unwaivable restrictions on umilateral self-help by licensors. See U.C.C. \& 2B-716(e) (Draft, Apr. 1998) ("The licensee cannot waive the protections of this section...."). But see id. $\S 2 \mathrm{~B}-716$, reporter's note 2(e) ("The rights under this Section cannot be waived prior to breach." (emphasis added)). The August Draft abolishes section 2B-716, with the result that unilateral self-help is virtually always permissible. For a discussion of the deficiencies in Article 2B's self-help proposals, see Cohen, supra note 4 . Even the weak protections of section 2B715, see U.C.C. \& 2B-715 (Draft, Aug. 1, 1998), do not extend to technological self-help imposed pursuant to anothcr self-help provision, section 2B-310, see id. § 2B-310.

32. In a market transaction, contract drafters will by and large be the intellectual property owners. But it is worth noting that large purchasers that draft intellectual property licensing agreements can also impose onerous terms on authors. See Ginsburg, supra note 4 (discussing this problem).

Article 2B section 2B-208(b) does create a right to a refund in mass-market shrinkwrap license transactions if the buyer has no opportumity to review the terms until after purchase and does not "manifest assent" to the terms by opening the package or using the software. See id. $\$ 2 \mathrm{~B}-208$ (b). This might be thought of as a "riglt" of purchasers that cannot be waived, although the August Draft doesn't explicitly say this. I do not mclude it in the list of provisions that can't be waived because it seems to defme what constitutes a contract in the first place, rather than what terms will be included. The same is true of Article $2 \mathrm{~B}$ sections $2 \mathrm{~B}-111$ and $2 \mathrm{~B}-112$, which define the terms "manifests assent" and "opportunity to review," see id. $\$ \S 2 B-111,2 B-112$, and section $2 \mathrm{~B}-201$, relatimg to the statute of frauds, see id. $\S 2 \mathrm{~B}-201$. All of these terms govern how a contract itself is created; they are necessarily mandatory rules in any contract statute. 


\section{B. Potential Conflicts with Intellectual Property Law}

Article 2B's expansion of contractual power sets up the potential for numerous conflicts between intellectual property and contract law. ${ }^{33}$ Intellectual property law is designed to provide creators with a limited set of rights over ideas and inventions in order to serve the instrumental purpose of encouraging more creation. ${ }^{34}$ For many good reasons, the law does not grant intellectual property owners boundless control over their creations. First, granting exclusive rights raises the cost of new works to the public, and in some cases means that the public won't get access to the works at all. ${ }^{35}$ Second, granting property rights to original

33. Article 2B's drafters indirectly acknowledge this. At the insistence of the ALI, they included section 2B-105, which states what one might otherwise consider obvious: in cases in which Article 2B rules conflict with federal law, federal law must prevail. See U.C.C. § 2B-I05(a) (Draft, Aug. 1, 1998). The ALI motion in fact called for something more than this tautology. For a discussion of the ALI vote, see McManis, supra note 14, at 176. Similarly, after NCCUSL insisted on a provision protecting the public policy in the free flow of information, the drafters added a highly watered-down version of such a limitation in Article 2B section 2B-105(b). See U.C.C. § 2B-105(b) (Draft, Aug. 1, 1998). Despite the NCCUSL vote, the current Draft proclaims that "[a] term or contract that results from an informed private agreement between commercial parties should be presumed to be valid and a lieavy burden of proof should be imposed on the party seeking to escape the terms of the agreement ...." Id. § 2B-105, reporter's note 3 .

On the basis of these provisions, one might assert that there is no "conflict" betwcen state and federal law; federal law can continue to govern intellectual property to the extent that it chooses. But this seems misleading. A state statute that by its own admission "push[es] against" fcderal law, see U.C.C. art. 2B Preface at 10 (Draft, Aug. 1, 1998), sets up conflicts between state and federal law. The fact that federal law wins in these cases of conflict doesn't inean that the conflict doesn't exist. Further, unless we assume that every contract dispute will be litigated, and that federal law will be brought into every suit under Article $2 \mathrm{~B}$, the new contract rules may have an effect on marginal cases that the prior contract regime would not. The effect might be in terrorem, or it might operate in cases where resource-poor defendants simply don't know anything about the complex and arcane rules of federal intellectual property law.

The reporter's notes to section 2B-208 also include a weak suggestion that contracts limiting certain user rights in intellectual property might be unconscionable. See U.C.C. § 2B-208 reporter's note 3(b) (Draft, Aug. 1, 1998). But the August Draft does not pursue this suggestion, and indeed acknowledges that federal policy will play the dominant role in determining how Article $2 \mathrm{~B}$ interacts with intellectual property law. See id.

34. See Lemley, Romantic Authorship, supra note 10, at $888-90$ (collecting some of the innumerable sources supporting this proposition). Even the list of Supreme Court decisions emphasizing this limited, instrumental purpose is impressive. See, e.g., Graham v. John Dcere Co., 383 U.S. 1, 9 (1966) ("The patent monopoly was not designed to secure to the inventor his natural right in his discoveries. Rather, it was a reward, an inducement, to bring forth new knowledge.'); Mazer v. Stem, 347 U.S. 201, 219 (1954) ("The economie philosophy behind the clause empowering Congress to grant patents and copyrights is the conviction that [it] is the best way to advance public welfare ...."); accord Fogerty v. Fantasy, Inc., 510 U.S. 517, 524 (1994); Feist Publications, Inc. v. Rural Tel. Serv. Co., Inc., 499 U.S. 340, 349-50 (1991); Stewart v. Abend, 495 U.S. 207, 225 (1990); Bonito Boats, Inc. v. Thunder Craft Boats, Inc., 489 U.S. 141, 167 (1989); Dowling v. United States, 473 U.S. 207 (1985); Sony Corp. of America v. Universal City Studios, Inc., 464 U.S. 417, 429 (1984); Twentieth Century Music Corp. v. Aiken, 422 U.S. 151, 156 (1975); Kewanee Oil Co. v. Bicron Corp., 416 U.S. 470, 476 (1974); Goldstein v. Califomia, 412 U.S. 546, 559 (1973); United States v. Paramount Pictures, Inc., 334 U.S. 131, 158 (1948).

35. See, e.g., New Era Publications Int'l v. Carol Publ'g Group, 904 F.2d 152, 185 (2d Cir. 1990) (involving litigation brought by the Church of Seientology to keep its works from being further 
creators allows them to prevent subsequent creators from building on their works, which means that a law designed to encourage the creation of first-generation works may actually risk stifling second-generation creative works. ${ }^{36}$ Third, the goal of intellectual property is only to provide the "optimal incentive," not the largest incentive possible. Past a certain point, it would be inefficient to withhold works from the public domain in order to provide ever-decreasing "incentives" to their creators. ${ }^{37}$ As Larry Lessig has observed, "while we protect real property to protect the owner from harm, we protect intellectual property to provide the owner sufficient incentive to produce such property. 'Sufficient incentive,' however, is something less than 'perfect control." "38

Giving the parties unlimited power under contract law to vary the rules of intellectual property creates considerable tension with this balanced incentive structure..$^{39}$ And permitting the parties to alter

distributed to the public); Salinger v. Random House, Inc., 811 F.2d 90, 94-95 (2d Cir. 1987) (involving litigation brought by J.D. Salinger to prevent any distribution of a book that contained excerpts from his private letters); Rosemount Enter. v. Random House, Inc., 366 F.2d 303, 306-07 (2d Cir. 1966) (asserting copyright law to suppress unauthorized biography of Howard Hughes); Religious Tech. Ctr. v. Netcom On-Line Communication Servs., Inc., 923 F. Supp. 1231, 1244 (N.D. Cal. 1995).

36. For more on this, see Lemley, Economics of Improvement, supra note 10, at 1042-72 (discussing the reasons copyriglt owners and improvers will not always come to terms through licensing). See also Wendy J. Gordon, Toward a Jurisprudence of Benefits: The Norms of Copyright and the Problem of Private Censorship, 57 U. CHI. L. REv. 1009, 1024 (1990).

37. Arguably we have reached this point already, Congress recently extended copyright protection from its current term of life plus fifty years to life plus seventy years. See H.R. 604, 105th Cong. (1997). I have never met anyone who seriously argued that the additional imcentive provided by the reward to great-grandchildren in the additional twenty years would actually make the difference in encouraging the creation of any new works.

38. Lawrence Lessig, Intellectual Property and Code, 11 ST. JoHN's J. LEGAL COMMENT. 635, 638 (1996); see also Dreyfuss, supra note 4, at 198 ("[A] core premise of federal innovation policy... [is] that information leaks: That is, knowledge flows inevitably into the domain of the public, where innovators can use what others liave learned and improve upon what they lave done.").

39. Jane Ginsburg notes that contract "may provide more effective protection than copyright" for some works. Jane C. Ginsburg, Copyright, Common Law, and Sui Generis Protection of Databases in the United States and Abroad, 66 U. CIN. L. REv. 151, 151 (1997) [hereinafter Ginsburg, Common Law]. Sle generally views this as a good thing, because she thinks that copyright provides inadequate incentives for protection. See id. at 171. But good or bad, this is still an acknowledgment that contract law changes the existing balance.

Elsewhere, Ginsburg challenges the very idea of a conflict of interests between authors and users. See Ginsburg, supra note 5, at 4 (calling "specious" the definition of the author's interests that holds that they are at odds with the public's). If her point is that authors and consumers should not always be at odds in copyright law, because consumers depend on wliat authors produce, I agree. But this does not mean that there is no tension between the interests of authors and those of consumers. Surely there is, just as there is tension between labor and management, or between buyers and sellers in any market arrangement. A law favoring management over labor may or may not be in the "public interest," defined in social terms, but it is unlikely to be in labor's interest.

Perhaps Ginsburg's point is that the "public interest" is an amalgam of the interests of everyone in society with a stake in the outcome, and cannot be identified solely by reference to consumers, or even by reference to users more broadly defined. Again, I would agree. But I know of no one who 
intellectual property law with a standard-form, unsigned "shrinkwrap license," in which even the fiction of "agreement" is stretched to the vanishing point, exalts the (standard) form of contract law over the substance of intellectual property. ${ }^{40}$

In the following Sections, I describe a few common contractual terms, which Article 2B would presumptively enforce and, in so doing, create tension with intellectual property law. ${ }^{41}$ While many of these common terms are found in contracts drafted by intellectual property owners that interfere with user rights, the reverse is also true-contract provisions drafted by licensees may also interfere with the rights of intellectual property owners. My purpose in the remainder of this Part is only to highlight these areas of potential conflict, and not (yet) to suggest how the conflicts should be resolved. Just because a contractual term creates tension with intellectual property law does not mean that it is necessarily unenforceable; I will focus my attention on what that tension means in the balance of the Article. ${ }^{42}$

\section{Patent Law}

Patent law confers broader rights on intellectual property owners than any other intellectual property law. ${ }^{43} 1 \mathrm{t}$ is therefore the least likely source of problems for the licensor; most of what a licensor wants, patent law already gives her. Nonetheless, patent licensors sometimes do seek to get more than federal patent policy will give them. Two such conflicts are particularly common.

First, licensors generally want licensees to agree not to dispute the validity of the patent being licensed. Licenses up until thirty years ago commonly included provisions by which the licensee agreed that the patent was valid, or at least not to challenge the validity of the patent in court. ${ }^{44}$ In Lear, Inc. v. Adkins, ${ }^{45}$ however, the Supreme Court held that licensees could not give up their rights to challenge the validity of a

has suggested that the public interest in copyright law should be defined only by reference to consumers. Indeed, the opposite danger seems far greater; in setting copyright policy, Congress today seems inclined to think only of the interests of publishers, and even then, only of current and not future publishers. See, e.g., S. 2037, 105th Cong. (1998). "Agnostics and atheists" inay be turning up among copyright lawyers and academies, as Ginsburg suggests, see Ginsburg, supra note 5, at 9, but the property rights priesthood is firmly in control of the lawnaking proeess.

40. See Lemley, Shrinkwrap Licenses, supra note 10, at 1264-69 (discussing the tension between particular intcllectual property rulcs and common shrinkwrap license terms).

41. Certain of these sections are adapted from Leinley, $i d$.

42. For some ways of analyzing and resolving these tensions, see infra Parts II, III.

43. See generally Robert P. Merges et al., Intellectual Property in the NeW TeChNological AgE 128-36 (1997) (discussing the general attributes of patent law and its theoretical basis).

44. See, e.g., Automatic Radio Mfg. Co., Inc. v. Hazeltine Research, Inc., 339 U.S. 827, 836 (1950), overruled in part by Lear, Inc. v. Adkins, 395 U.S. 653 (1969).

45. 395 U.S. $653,670-71$ (1969). 
patent. In that case, the Court expressly rejected on preemption grounds a contract that attempted to "opt out" of the distribution of rights established by patent law. ${ }^{46}$

Second, patentees periodically attempt to extend their control over licensees beyond the scope of the patent itself. They may do this by granting licenses that: (1) extend the term of the patent beyond seventeen years; ${ }^{47}$ (2) tie patented to unpatented products in an attempt to capture the market for both;8 (3) require that the licensee grant back the rights to any improvement patents; ${ }^{49}$ or (4) employ other means. Contracts that accomplish such an extension of the patent monopoly have received mixed treatment by the courts. Some clauses, particularly those that extend the length of the patent or copyright term, have been declared unenforceable. ${ }^{50}$ Others, particularly grantback clauses, are generally enforceable if they do not run afoul of the antitrust laws. ${ }^{51}$ In certain circumstances, courts not only refuse to enforce the license provision; they also punish the patentee for insisting upon it by declaring the entire patent unenforceable. ${ }^{52}$ But in any event, it is federal patent policy, not the contract term, that controls the transaction.

Patent contracts can also run afoul of the doctrine of assignor estoppel. Unlike licensee estoppel, which Lear prohibits, assignor estoppel prevents the original inventor and her company from challenging the validity of a patent issued on her own invention, and then assigned to

46. See id. at 668-71; cf. Sola Elec. Co. v. Jefferson Elec. Co., 317 U.S. 173, 176-77 (1942) (holding that federal law preeinpts state rules estopping licensees froin contesting patent practices that violate antitrust law). The Federal Circuit has recently criticized the opinion in Lear and issued a decision that is flatly inconsistent with it in one respect. See Studiengesellschaft Kohle M.B.H. v. Shell Oil Co., 112 F.3d 1561, 1567 (Fed. Cir. 1997) (criticizing Lear as reflecting a misguided skepticisn towards intellectual property, and holding that licensees who successfully challenge the validity of a patent may nonetheless have to pay royalties to the owner of the invalid patcnt), cert. denied, 118 S. Ct. 560 (1997). But Lear's rejection of contract terms binding licensees not to contest the validity of the licensed patent, see 395 U.S. at 670-71, remains good law. For a discussion of this issue, see Rochelle C. Dreyfuss, Dethroning Lear: Licensee Estoppel and the Incentive to Innovate, 72 VA. L. REv. 677 (1986); Nellie A. Fisher, The Licensee's Choice: Mechanics of Successfully Challenging $a$ Patent Under License, 6 TEX. INTELL. Prop. L.J. 1 (1997).

47. See, e.g., Brulotte v. Thys Co., 379 U.S. 29, 33 (1964).

48. See, e.g., Dawson Chemical Co. v. Rohm \& Haas Co., 448 U.S. 176, 179 (1980).

49. Such provisions are referred to as "grantback" clauses. See MERGES ET AL., supra note 43, at $1089-90$.

50. See Meehan v. PPG Indus., 802 F.2d 881, 886 (7th Cir. 1986); Boggild v. Kenner Prods., 776 F.2d 1315, 1320-21 (6th Cir. 1985); cf. P.C. Films Corp. v. MGM/UA Home Video Inc., 138 F.3d 453, 458 (2d Cir. 1998) (suggesting in dictum that copyright owners cannot impose license restrictions after the copyright expires). But cf. Howard v. Sterchi, 974 F.2d 1272, 1277 (11th Cir. 1992) (enforcing a contract that extended beyond the expiration of the copyright without considering preemption or copyright misuse issues).

51. See U.S. Dept. of Justice \& Federal Trade Comm'n, Antitrust Guidelines for the Licensing of Intellectual Property $\$ 5.6$ (1995).

52. This is the patent misuse doctrine. For a description of its scope, see Mark A. Lemley, Comment, The Economic Irrationality of the Patent Misuse Doctrine, 78 CALIF. L. REv. 1599, 161113 (1990). 
the ultimate patent owner. ${ }^{53}$ The Federal Circuit has held that inventors will be estopped from contesting the validity of their own patents as a matter of judicial policy. ${ }^{54}$ This policy applies whether or not the inventor sought to reserve the right to challenge the patent when she entered into the assignment agreeinent. ${ }^{55}$

\section{Copyright Law}

Copyright law contains a number of compromises between the desires of authors and those of the consuming public. It is therefore not surprising that contracts written by a copyright owner often claim to give the licensor greater rights than are granted by copyright law. Similarly, contracts written by an assignee or licensee sometimes seek to take away rights that the copyright law grants exclusively to authors. Several examples follow.

First, some contracts provide that the licensee may not make any copies of the licensed work. If the copyrighted work is a computer program, such a license term conflicts directly with section 117 of the Copyright Act, which gives owners of a copy of a program the right to make both archival copies and copies necessary to run the program. ${ }^{56}$ In soine cases, the license term inay also run afoul of the right to make "fair use" of the copyrighted work. ${ }^{57}$ Indeed, it is not very hard to find

53. See, e.g., Diamond Scientific Co. v. Ambico, Inc., 848 F.2d 1220, 1224 (Fed. Cir. 1988).

54. See id. at 1224-26.

55. In Diamond Scientific, the court held that patent policy absolutely barred assignors from later contesting the validity of the patent they assigned. See id. By contrast, Judge Newman, concurring, objected to this public policy rationale, and would instead have trcated both assignor and licensee estoppel as matters for determination by contract law. See id. at 1227-28 (Ncwman, J., concurring).

56. 17 U.S.C. $\$ 117$ (1994); see also Vault Corp. v. Quaid Software Ltd., 847 F.2d 255, 270 (5th Cir. 1988) (holding that section 117 authorized defendant to make a copy that was neccssary to analyze and defeat a copyrighted "anticopying" program); Foresight Resources Corp. v. Pfortmiller, 719 F. Supp. 1006, 1009-10 (D. Kan. 1989); John Conley \& Vance Brown, Revisiting \$ 117 of the Copyright Act: An Economic Approach, CoMPuTER L., Nov. 1990, at 1. The term "owners of a copy," which snuck into section 117 for reasons no one has been able to determine, has caused some courts to focus on whether the user is really an "owner" or a "licensee." See MAI Sys. Corp. v. Pcak Computer, Inc., 991 F.2d 511, 519 n.5 (9th Cir. 1993) (finding that section 117 does not apply to software that is licensed, not sold, since the user of such software is not the "owner" of a copy, and concluding that the customer could not hire a third party to install or debug purchased program). But see DSC Communications Corp. v. Pulse Communications Inc., 976 F. Supp. 359, 362 (E.D. Va. 1997) (holding that whether defendant "owns" a copy under section 117 is determined by the economic realities of the transaction, not by whether it is characterized as a "license").

57. See 17 U.S.C. \$ 107 (1994). "Fair use" is an amorphous concept, so generalizations are difficult. But possible fair use copies of computer programs may include: (1) reverse engineering the work in order to view and use uncopyrighted elemcnts, see infra note 62; (2) copying a program into RAM inemory in order to use it; (3) copying part or all of the work for the purpose of instruction in a computer science class; (4) copying part or all of the work for the purpose of acadeinic research; and (5) working copies of portions of electronic or print instruction manuals. 
contractual provisions that claim to preclude any copying by the user, whether or not the copying would be fair use. ${ }^{58}$ And one can certainly imagine copyright owners including "no-parody" provisions in their licenses, if courts would enforce them. But fair use is designed precisely to allow nonconsensual uses, ${ }^{59}$ and "contracting around" fair use thus presents a conflict with the goals of the doctrine..$^{60}$

Second, many software contracts purport to prohibit reverse engineering of the licensed software. ${ }^{61}$ These terms may conflict with a user's apparent right under copyright law to reverse engineer copyrighted works for certain purposes. ${ }^{62}$ This is perhaps the most common

For a discussion of the possibility of contracting out of fair use, see Jane C. Ginsburg, Copyright Without Walls?: Speculations on Literary Property in the Library of the Future, 42 REPRESENTATIONS 53, 61-66 (1993).

58. See, e.g., Rick Feinberg, Pecultar Patents at iv (1994) ("No part of this book may be reproduced in any form, except by a newspaper or magazine reviewer who wishes to quote brief passages in connection with a review.").

59. See, e.g., William W. Fisher III, Reconstructing the Fair Use Doctrine, 101 HARV. L. REV. 1659, 1687 (1988); Gideon Parchomovsky, Fair Use, Efficiency, and Corrective Justice, 3 LEGAL Theory 347, 359-60 (1997); cf. Merges, supra note 1, at 1610 (suggesting that as transaction costs disappear, the prinary role for fair use will be to privilege certain nonconsensual uses).

Wendy Gordon has suggested that fair use is best conceived as directed at "market failure." See Wendy J. Gordon, Fair Use As Market Failure: A Structural and Economic Analysis of the Betamax Case and Its Predecessors, 82 CoLuM. L. REv. 1600 (1982). If market failure is construed broadly enough to encompass situations in which socially efficient licensing does not occur, I agree. See Lemley, Economics of Improvement, supra note 10, at 1077-83. But it seens obvious that fair use must offer users something more than simply the "implied consent" of the copyright owner in circumstances in which it is not worth the cost to bargain over a license. Were that all that the fair use doctrine protected, it would not cover true "nonconsensual" uses. But it does. See, e.g., Campbell v. Acuff-Rose Music, Inc., 510 U.S. 569 (1994) (finding parody protected by fair use).

60. See Neil Weinstock Netanel, Copyright and a Democratic Civil Society, 106 YALE L.J. 283, 362 (1996) ("Th[e] imposition of limits [on copyright] must be seen as a vital and integral part of copyright's structural function.").

61. Reverse engineering of software-also called "decounpilation"-involves working backwards from object code to produce a simulacrum of the original source code. See Andrew Johnson-Laird, Software Reverse Engineering in the Real World, 19 U. DAYTON L. REv. 843 (1994).

62. Virtually all recent courts, as well as most commentators, have endorsed reverse engineering in soine circumstances, particularly when necessary to achieve interoperability. See, e.g., DSC Communications Corp. v. DGI Techs., Inc., 81 F.3d 597, 601 (5th Cir. 1996); Batenuan v. Mnemonics, Inc., 79 F.3d 1532, 1539 n.18 (11th Cir. 1995); Lotus Dev. Corp. v. Borland Int'1, Inc., 49 F.3d 807, 817-18 (1st Cir. 1995); Sega Enterprises Inc. v. Accolade, Inc., 977 F.2d 1510, 1527-28 (9th Cir. 1992); Atari Games Corp. v. Nintendo of Am. Inc., 975 F.2d 832, 843-44 (Fed. Cir. 1992); Vault Corp. v. Quaid Software Ltd., 847 F.2d 255, 270 (5th Cir. 1988); DSC Commumications Corp. v. Pulse Communications Inc., 976 F. Supp. 359, 364 (E.D. Va. 1997); Mitel, Inc. v. Iqtel, Inc., 896 F. Supp. 1050, 1056-57 (D. Colo. 1995), aff'd on other grounds, 124 F.3d 1366 (10th Cir. 1997); JonATHAN BAND \& Masanobu KatoH, INTERfaces ON TRIAL (1995); Julie E. Cohen, Reverse Engineering and the Rise of Electronic Vigilantism: Intellectual Property Implications of "Lock-Out" Programs, 68 S. CAL. L. Rev. 1091 (1995); Lawrence D. Graham \& Richard O. Zerbe, Jr., Economically Efficient Treatment of Computer Software: Reverse Engineering, Protection, and Disclosure, 22 Rutgers Computer \& Tech. LJ. 61 (1996); Dennis S. Karjala, Copyright Protection of Computer Programs, Reverse Engineering, and Professor Miller, 19 U. DAYTON L. REV. 975, 1016-18 (1994); Maureen A. O'Rourke, Drawing the Boundary Between Copyright and Contract: Copyright Preemption of Software License Terms, 45 DUKE LJ. 479, 534 (1995); David A. Rice, Sega and 
example in the software industry of a conflict between contractual terms and copyright policy.

Third, software and digital information contract terms often seek to prohibit the licensee froin moving a program to an upgraded computer or from altering, upgrading, or "debugging" the program. Such requirements may conflict with at least the spirit, and arguably the letter, of section 117, which gives users the right to copy and adapt the program to the extent necessary to run it on a particular machine. ${ }^{63}$ In particular, section 117 was intended to give users the right to upgrade programs themselves, ${ }^{64}$ and to transfer software programs to newer

Beyond: A Beacon for Fair Use Analysis... At Least As Far As It Goes, 19 U. DAYTON L. REv. 1131, 1168 (1994); Pamela Samuelson, Fair Use for Computer Programs and Other Copyrightable Works in Digital Form: The Implications of Sony, Galoob and Sega, 1 J. INTELL. Prop. L. 49 (1993); Timothy S. Teter, Note, Merger and the Machines: An Analysis of the Pro-Compatibility Trend in Computer Software Copyright Cases, 45 STAN. L. REv. 1061 (1993) (arguing that the value of computer programs depends on interoperability).

On the other hand, a few early decisions rejected interoperability as a justification for copying. See Apple Coinputer, Inc. v. Franklin Computer Corp., 714 F.2d 1240, 1253 (3d Cir. 1983); Digital Communications Assoc., Inc. v. Softklone Distrib. Corp., 659 F. Supp. 449, 462 (N.D. Ga. 1987); see also Anthony L. Clapes, Confessions of an Amicus Curiae: Technophobia, Law, and Creativity in the Digital Arts, 19 U. DAYTon L. REv. 903 (1994) (contending that there is no right to reverse engineer software); Arthur R. Milier, Copyright Protection for Computer Programs, Databases, and ComputerGenerated Works: Is Anything New Since CONTU?, 106 HARv. L. REv. 977 (1993) (same).

63. See 17 U.S.C. $\S 117$ (1994). The right to adapt software has been the subject of numerous and conflicting court decisions. See generally Marvin N. Bean \& Richard J. Superfine, \$ 1I7-The Right to Adapt into the Fourth Generation and the Source Code Generator's Dilemma, $12 \mathrm{~J}$. Marshall J. Computer \& INFo. L. 537 (1994) (discussing section 117 caselaw).

Some courts have held that because of the nature of computer technology, using a prograin on a inodern computer network necessarily inakes several copies of that program. See, e.g., MAI Sys. Corp. v. Peak Computer, Inc., 991 F.2d 511, 518 (9th Cir. 1993). For criticism of MAI, see Fred H. Cate, Law in Cyberspace, 39 How. L.J. 565, $575-77$ (1996); Margaret Chon, New Wine Bursting from Old Bottles: Collaborative Internet Art, Joint Works, and Entrepreneurship, 75 OR. L. REv. 257, 26061 (1996); Niva Elkin-Koren, Copyright Lav and Social Dialogue on the Information Superhighway: The Case Against Copyright Liability of Bulletin Board Operators, 13 CARDOzo ARTS \& ENT. L.J. 345, 381-82 (1995); Lemley, Overlapping Copyrights, supra note 15, at 550-552; Jessica Litunan, The Exclusive Right to Read, 13 CARDozo ARTs \& ENT. L.J. 29, $41-43$ (1994); Litman, supra note 11, at 21; James V. Mahon, A Commentary on Proposals for Copyright Protection on the National Information Infrastructure, 22 RuTGERS COMPUTER \& TECH. L.J. 233, 240-45 (1996); James A.D. White, Misuse or Fair Use? That ls the Software Copyright Question, 12 BERKELEY TECH. L.J. 251, 302-05 (1997); Barbara Cohen, Note, A Proposed Regime for Copyright Protection on the Internet, 22 BRooK. J. INT'L L. 401, 412 (1996); Michael E. Johnson, Note, The Uncertain Future of Computer Software Users' Rights in the Aftermath of MAI Systeins, 44 DuKE L.J. 327 (1994); Katrine Levin, Note, MAI v. Peak: Should Loading Operating System Software into RAM Constitute Copyright Infringement? 24 GoldEN GATE U.L. REV. 649 (1994); Carol G. Stovsky, Note, MAI Systems Corp. v. Peak Coinputer, Inc.: Using Copyright Law to Prohibit Unauthorized Use of Computer Software, 56 OHIO ST. L.J. 593 (1995). Copyright law places strict limitations on a purchaser's right to use a program in a networked environment. See Lemley, Overlapping Copyrights, supra note 15, at 550-67. Because of this, most medium-sized and large corporations have begun purchasing "site-licenses" from software vendors. See Thomas M.S. Hemnes, Software Revenue Generation in Network Environments, 33 JURIMETRICs J. 377, 381 (1993) ("Site licenses are understandably popular . ....").

64. See Ayınes v. Bonnelli, 47 F.3d 23, 26 (2d Cir. 1995); Final Report of the Commission on New Technological Uses of Copyrighted Works 25 (1978) [hereinafter CONTU Report]. 
hardware or operating systems, even if the transfer requires translation of the code. ${ }^{65}$

Fourth, contract terms commonly prohibit licensees from transferring or assigning their particular copy of a work. Such provisions may conflict with the "first sale" doctrine in copyright law, which gives the owner of a particular copy of a copyrighted work the right to dispose of that copy without the permission of the copyright owner. ${ }^{66}$ Whether this is actually a conflict depends on whether the copyright owner "sold" or "licensed" the copy in question; the first sale doctrine does not prevent restrictions on the transfer of licensed items. ${ }^{67}$

Fifth, contractual provisions may seek to prevent the user of a copyrighted work from perforining or displaying the program to the public under any circumstances. ${ }^{68}$ Such a license provision would conflict with section 110 of the Copyright Act, which expressly immunizes certain performances. ${ }^{69}$ Similarly, limitations on certain uses of some types of works may run afoul of other specific exceptions in the Copyright Act, such as the right of libraries to make certain copies, ${ }^{70}$ the right of cable and satellite systems to engage in secondary transmission and simultaneous copying subject to compulsory licenses, ${ }^{71}$ the rights to make photographic reproductions of some types of copyrighted works without authorization, ${ }^{72}$ and the right to play inusic in jukeboxes subject to an arbitrated coinpulsory license. ${ }^{73}$

Sixth, copyright owners are granted certain rights that they cannot waive, assign, or license. Most notable here is the right of authors to terminate transfers of rights in the work between thirty-five and forty years after the work was created. $^{74}$ This right is effective

65. See CONTU Report, supra note 64, at 25 ("[A] right to make those changes necessary to enable the use for which [the software] was both sold and purchased should be provided. The conversion of a program from one higher-level language to another to facilitate use would fall within this right.").

66. See 17 U.S.C. $\$ 109$ (a) (1994). Section 109(b)(1)(A) contains an exception prohibiting the purchasers of computer software from renting that software for profit, but does allow purchasers to sell the copy or give it away. $I d . \$ 109$ (b)(1)(A).

67. See H.R. 94-1476, 94th Cong. (1976) (providing that the parties may contract around the first sale doctrine in 17 U.S.C. $\S 109$ (a), but limiting the copyright owner to contract rather than copyright remedies if they do so).

68. For example, movies rented by a video store commonly provide that they are "licensed for home use only" and not for public performance.

69. 17 U.S.C. $\$ 110$ (1994) (offering limited protections for educational, religious, agricultural, and charitable performances).

70. See id. $\$ 108$.

71. See generally id. $\S \S 111,112,119$ (setting out the provisions of the cable and satellite compulsory licenses).

72. See id. $\$ \$ 113$ (c) (useful articles), 120 (architectural works).

73. See id. $\$ 116$.

74. See id. § 203(a)(3); see also id. \$ 304(c)(3) (providing a similar right for older works). 
"notwithstanding any agreement to the contrary." Similarly, the limited moral rights of a visual artist may not be transferred by the author, even if the copyright is assigned; any waivers of the artist's moral rights are strictly limited by statute. ${ }^{76}$ Contractual provisions that purport to transfer rights in violation of these provisions present obvious conflicts with the Copyright Act.

Seventh, the Copyright Act specifically defines works "made for hire," and therefore the terms of initial ownership of copyrighted works. ${ }^{77}$ It also governs the way in which transfers of copyright ownership may be made, ${ }^{78}$ and precludes oral assigninent agreements. ${ }^{79}$ An agreement that purports to assign a copyright, but that does not comply with the terms of section 204, conflicts with the Copyright Act. Contract law rules that are inconsistent with section 205(d) also set up a conflict, as would contracts that purported to create "works nade for hire" but do not fall within the definition of that term in the statute.

Finally, a contract may "shrink the public domain" by withdrawing from public use certain works that are not subject to intellectual property protection..$^{80}$ This is what happened in the ProCD case, ${ }^{81}$ in which the plaintiffs were allowed to protect by shrinkwrap license the very material that the Supreme Court had said could not be protected by copyright. ${ }^{82}$

Whether this is really a "conflict" in any given case is a coinplex question. Some uncopyrightable materials can be protected under other laws. For exainple, uncopyrightable information may be patentable, capable of trade secret protection, or protected by common law copyright. ${ }^{83}$ The Supreme Court in Goldstein v. California ${ }^{84}$ observed that the central question is whether the work was denied protection because of a federal determination that it should be unprotected, or whether the federal statute simply did not extend to such a work. Only in the latter case can states "remove" works from the public domain. ${ }^{85}$ In cases in which contracts purport to protect information in spite of a federal

\footnotetext{
75. Id. §§ 203(a)(5), 304(c)(5).

76. See id. § 106A(e)(1).

77. See id. \&101(2).

78. See id. \& 205(d).

79. See id. § 204.

80. Minassian, supra note 20, at 593.

81. ProCD, Inc. v. Zeidenberg, 86 F.3d 1447 (7th Cir. 1996).

82. See Feist Publications, Inc. v. Rural Tel. Servs. Co, Inc., 499 U.S. 340 (1991) (holding that copyright protection is unavailable for telephone white pages).

83. On the limits of common law copyright, see Estate of Hemingway v. Random House, Inc., 244 N.E.2d 250, 255-56 (N.Y. 1968), in which the court held that Ernest Hcmingway's oral statements could not be protected by common law copyright.

84. 412 U.S. 546 (1973).

85. Id. at 559 .
} 
determination that such information should be unprotected, they will conflict with federal policy. ${ }^{86}$

\section{Trade Secret Law}

Protection for trade secrets is largely provided by state statutes or common law, supplemented by federal law. ${ }^{87}$ These legal rules often conflict with the desires of licensors. The most common conflicts involve contractual terms drafted by licensors that prohibit reverse engineering or obviate the need for secrecy. Reverse engineering of a trade secret is explicitly allowed by the Uniform Trade Secrets Act, which means that the Act conflicts with contract law if the contract provides that a licensee may not reverse engineer the licensed product. ${ }^{88}$ Similarly, license terms that prevent the licensee from challenging the status of software as a trade secret are in apparent conflict with the legal requirement that a trade secret inust in fact be secret to be protectable. ${ }^{89}$

Trade secrets law in inost states also places limitations on the enforceability of employee noncompetition agreements and "trailer

86. For example, in Saturday Evening Post v. Rumbleseat Press, 86 F.2d 1191 (7th Cir. 1987), Judge Posner held unenforceable an express agreement by a licensee not to challenge the copyrightability of the licensed work.

87. The Uniform Trade Secrets Act has been adopted by forty-two jurisdictions as of this writing. See CAL. CIv. CODE $\$ 3426.1$, Preface (Deering 1997) (listing jurisdictions and statutes). Most other states follow the Restatement of ToRTs, $\$ \S 757-758$ (1937). See, e.g., Hyde Corp. v. Huffines, 314 S.W.2d 763 (Tex. 1958).

Federal law provides for criminal hability for misappropriation of trade secrets in sone circumstances through the Economic Espionage Act. See 18 U.S.C. \$\$ 1831-1839; see also James H.A. Pooley et al., Understanding the Economic Espionage Act of 1996, 5 TEX. INTELL. Prop. LJ. 177 (1997) (evaluating the Act). There is also a limited role for federal civil protection of trade secrets in cases in which states provide protection that does not comply with United States treaty obligations to foreign countries. See Litton Sys., Inc. v. Ssangyong Cement Indus. Co., No. C-89-3832 VRW, 1993 U.S. Dist. LEXIS 12198, at *1 (N.D. Cal. Aug. 19, 1993) (implying a federal trade secret claim under section 44 of the Lanham Act, 15 U.S.C. \$ 1127 , m order to comply with United States treaty obligations to South Korea); see also General Agreentent on Tariffs and Trade, Dec. 15, 1993, art. 39(1) [hereinafter GATT TRIPS] (requiring nteunber nations to provide minimum levels of trade secret protection); North American Free Trade Agreement art. 1711 (1994) (same).

88. See Uniform Trade Secrets Act $\S 1$ commissioners' cmt. (1985); RESTATEMENT OF TORTS, $\S 757$ cnit. f (1937).

89. See Uniform Trade Secrets Act \$ 1(4). Whether contract law can provide protection for a trade secret owner after the secret has been publicly disclosed is a hotly debated question. Compare Warner-Lambert Pharm. Co. v. John J. Reynolds, Inc., 178 F. Supp. 655, 663-67 (S.D.N.Y. 1959) (holding contract to pay royalties enforceable even after secret has been disclosed), with Restatement (ThIRD) of UNFaIR COMPETITION $\$ \S 39 \mathrm{cmt}$. d; $41, \mathrm{cmt}$ d (1993) (suggesting that public policy may render agreements purporting to protect information in the public domain unenforceable), Sarkes Tarzian, Inc. v. Audio Devices, Inc., 166 F. Supp. 250, 279-80 (S.D. Cal. 1958), aff d, 283 F.2d 695 (9th Cir. 1960) (same), and Gary Van Zeeland Talent, Inc. v. Sandas, 267 N.W.2d 242, 250 (Wis. 1978) (same). Cf. Aronson v. Quick Point Pencil Co., 440 U.S. 257 (1979) (finding that a contract obligated the licensee to continue paying royalties on an invention even after patent application was rejected; but the application may still have been a trade secret). 
clauses." ${ }^{90}$ At a mimimum, states impose an overarching requirement of "reasonableness" on such agreements, viewing them with disfavor and requiring that they be limited in scope and duration and not violative of other public policies. ${ }^{91}$ Other states refuse to enforce employee noncompetition agreements at all, ${ }^{92}$ or limit their enforcement to longterm rather than at-will employment contracts. ${ }^{93}$ Obviously, all of these public-policy limitations are in tension with the contractual terms they restrict.

\section{Trademark Law}

Federal trademark law is designed to prevent consumer confusion in the marketplace by encouraging competitors to use distinctive marks to identify their goods, which allows consumers to distinguish those goods from a competitor's. ${ }^{94}$ In order to prevent trademarks from becoming an instrument of consumer confusion, Umited States trademark law places sigmificant restrictions on a trademark owner's ability to sell or license the mark. These restrictions take two basic forms. First, trademarks cannot be assigned "in gross"-that is, without the goodwill and other assets accoinpanying the line of business the trademark represents. ${ }^{95}$ Second, if a trademark owner licenses the right to produce or sell tradeinarked goods to another, the owner must supervise the licensee to

90. A "trailer clause" is a contractual provision that requires employees to assign their rights not only in inventions made during the period of employment, but also for a certain time after the employment ends. See MERGES ET AL., supra note 43, at 99-100.

91. See, e.g., Comprehensive Techs. Int'l, Inc. v. Software Artisans, Inc., 3 F.3d 730, 737 (4th Cir. 1993) (applying Virginia law), judgment vacated on stipulation of dismissal, No. 92-1837, 1993 U.S. App. LEXIS 28601, at *1 (4th Cir. Sept. 30, 1993); Recd, Roberts Assoc., Inc. v. Strauman, 353 N.E.2d 590, 677 (N.Y. 1976).

92. California is most notable here. See CAL. Bus. \& PRof. Code § 16600 (Deering 1992); Monogram Indus., Inc. v. SAR Indus., Inc., 143 Cal. Rptr. 714, 718 (Cal. Ct. App. 1976) ("1n California with certain limited exceptions [not relevant here] a contract under which a person is prevented from engaging in a profession, trade or business is void."). For arguments that California's rule agamst enforcing noncompetition agreements has encouraged innovation in Silicon Vallcy, sce Annalee Saxenian, Regional Advantage 128 (1994); Alan Hyde, How Silicon Valley Has Eliminated Trade Secrets (And Why This Is Efficient) (1997) (unpublished manuscript, available at $<$ http://andromeda.rutgers.edu/ hyde/silicon2.html >).

93. See Light v. Centel Cellular Co. of Tex., 883 S.W.2d 642, 644-45 (Tex. 1994); cf. Central Adjustment Bureau, Inc. v. Ingram, 678 S.W.2d 28, 33 (Tenn. 1984) (finding noncompetition agreement enforceable where continuous long-term employment constituted considcration).

94. See MERGES ET AL., supra note 43, at 523-30.

95. The Lanham Act phrases this as an affirmative power-the trademark owner can assign the mark with accompanying goodwill. See 15 U.S.C. $\$ 1060$ (1994). But the cffect is the same as a prohibition. See $2 \mathrm{~J}$. Thomas McCarthy, McCarthy on Trademarks and Unfalr Competition $\$ 18.1$ (1997) [hereinafter MCCARTHY ON Trademarks]; MERGES ET AL., supra note 43, at 698-99 (discussing the assignments in gross rule). It is worth noting that the rule outside the United States permits assignments in gross, see GATT TRIPS, supra note 87, at art. 21, and that the rule in the United States has been relaxed sonuewhat in recent years, see In re Roman Cleanser Co., 802 F.2d 207, 208-09 (6th Cir. 1986). 
make sure that the goods produced or sold under the trademark are of comparable quality to existing trademarked products. ${ }^{96}$ Failure to comply with these rules can invalidate the trademark altogether. ${ }^{97}$

Correspondingly, garden-variety breach of contract disputes in trademark license cases may have overtones of federal policy. For example, the right to sell goods produced pursuant to a contract in mitigation of breach is an ordinary part of Umiform Commercial Code Article $2 .^{98}$ But if the rejected goods contain the licensor's trademark, reselling them can do significant damage to the principles of trademark law, and may be forbidden under federal law. ${ }^{99}$ These policy-based contract limitations set up a conflict with the free alienability that is normally a part of state contract law, although given the current scope of the Article $2 \mathrm{~B}$ (which does not extend to trademark licenses), ${ }^{100}$ it is not a problem for the August Draft.

\section{Remedies}

By and large, intellectual property law provides for strong property entitlements while contract law does not. ${ }^{101}$ The parties to an intellectual property license can agree to fix remedies withm the bounds of the intellectual property right. For example, Robert Merges has discussed a number of examples of what he calls "contracting into liability rules," in which parties agree to forego their entitlement to injunctive relief $\dot{m}$ a licensing transaction. ${ }^{102}$ Presumably they are free to do this without any constraint from intellectual property law.

But Article 2B allows intellectual property owners to do the reverse as well-to specify property-rule remedies for breach of contract. ${ }^{103}$

96. See Dawn Donut Co., Inc. v. Hart's Food Stores, Inc., 267 F.2d 358, 366 (2d Cir. 1959).

97. See, e.g., American Steel Foundries v. Robertson, Comm'r, 269 U.S. 372, 380 (1926) (discussing assignment in gross rule); Stanfield v. Osborne Indus., Inc., 52 F.3d 867, 871-72 (10th Cir. 1995) (finding trademark rights lost due to unsupervised license); Pepsico, Inc. v. Grapette Co., Inc., 416 F.2d 285, 289-90 (8th Cir. 1969) (invalidating assignment in gross).

98. See U.C.C. \$ 2-703 (1994).

99. See, e.g., Burberry's (Wholesale) Ltd. v. After Six Inc., 471 N.Y.S.2d 235 (Sup. Ct. 1984), discussed in Merges, supra note 1, at 1594-97.

100. See U.C.C. § 2B-104(2) (Draft, Aug. 1, 1998).

101. See MERGES ET AL., supra note 43, at 297.

102. Robert P. Merges, Contracting into Liability Rules: Intellectual Property Rights and Collective Rights Organizations, 84 CALIF. L. REv. 1293, 1293 (1996).

103. Article 2B provides that the parties can contract for specific performance of any obligation, including a personal service obligation, see U.C.C. $\$ 2 B-711$ (a)(1) (Draft, Aug. 1, 1998), provided that it will not create an administrative burden for the court, see id. $\$ 2 B-711$, reportcr's note 1 . That personal service obligations will be enforced if the parties so agree is clear from the plain language of the section, though a reporter's note suggests otherwise. See id. $\$ 2$ B-711, reporter's note 2 ("Specific performance cannot be ordered for a 'personal services contract."). More generally, section 2B-703(a) provides that the parties can agree to whatever remedies they like. Id. $\S 2 \mathrm{~B}-703(\mathrm{a})$. Indecd, the reporter's notes indicate that Article $2 \mathrm{~B}$ expressly permits cumulative 
Furthermore, Article 2B provides that breach of a license by the licensee may give rise not only to a cause of action for breach of contract, but also for copyright or patent infringement. ${ }^{104}$ While there is no direct conflict with federal law here, there is some tension. If a license term that goes further than federal intellectual property law can be enforeed by a suit for infringement or its equivalent, the federal law has been expanded just as effectively as if the statute were rewritten. ${ }^{105}$

\section{Conclusions}

Intellectual property law provides a set of rules to define and limit the rights it creates. Some of those rules are designed to be altered by contract, but others are not. Article 2B would superimpose a rule that all statutory provisions could be waived by contract-and indeed by a form shrinkwrap license that the licensee could not even read, much less agree to, before entering into the transaction. Creating such a contract regime threatens the integrity of the federal structure in a variety of ways; federal law must therefore deal with the tensions Article $2 \mathrm{~B}$ will create. In the next two Parts, I discuss how federal law and policy might respond to Article 2B.

\section{II \\ Preemption as a Partial Solution}

Two extreme solutions are available to reconcile the conflict between freedoin of contract and intellectual property policy ${ }^{106}$ First, one might sinply say that state enforceinent of any contractual provision that is at odds with an intellectual property rule is preempted by intellectual property law. Alternatively, one might say that contracts are not affected by intellectual property policy, and that parties are therefore free to alter intellectual property rules at will. Neither approach is particularly satisfactory. Contract law and intellectual property law both serve important goals, and when those goals come into conflict, we need some less arbitrary means of reconciling them. In this Part, I consider

remedies, and that Article 2B “rejects any concept of election of remedies." Id. § 2B-701, reporter's note 2 .

104. See U.C.C. § 2B-208, reporter's note 5(a) (Draft, Aug. 1, 1998); Microsoft Corp. v. Harmony Computers \& Elecs., Inc., 846 F. Supp. 208, 214 (E.D.N.Y. 1994) (holding that use in violation of the license is infringement, not merely breach of contract).

105. See Merges, supra note 1, at 1604 ("Courts must not allow a licensor who has bargained into a private liability rule to reimpose umilaterally the strong property rule by dint of an allencompassing termination right."). On the interaction between intellectual property and contract remedies generally, see Maureen A. O'Rourke, Rethinking Remedies at the Intersection of Intellectual Property and Contract: Toward a Unified Body of Law, 82 IowA L REv. 1137 (1997).

106. See I. Trotter Hardy, Contracts, Copyright and Preemption in a Digital World, 1 RICHMOND J.L. \& TECH. art. 2, II 37-43 (Apr. 17, 1995) <http://www.urich.edw/ jolt/v1i1/hardy.html> (noting two stylized views of the contract preemption issue). 
the extent to which federal preemption law succeeds in resolving the intellectual property-contract conflict. First, I discuss the nature of intellectual property preemption. I then consider the limits of preemption doctrine. I ultimately argue that while preemption has an important role to play in resolving the conflicts that Article $2 \mathrm{~B}$ will create, it cannot and will not solve the problem alone.

\section{A. The Nature of Intellectual Property Preemption ${ }^{107}$}

The issue of preemption is clouded by three factors. First, while all preemption is based on a conflict between a federal statutory scheme and a state law, courts in practice have developed different types of preemption doctrines, each of which has different standards. Second, there are different federal intellectual property statutes at issue, each of which has developed its own unique set of rules for applying preemption doctrine. Third, the issue is not the relatively smiple one of whether to preempt a particular state statute, but the more complex one of whether and how to preempt certain parts of contract law without bringing down the whole edifice. ${ }^{108}$

\section{The Basic Nature of Preemption}

While all federal preemption ultimately is based on the Supremacy Clause and the nature of federal law, several different types of general federal preemption exist. First, Congress may "preempt the field" by declaring that only federal law will govern a certain area. It is wellestablished that Congress has the power to do this in areas in which it is authorized to legislate. ${ }^{109}$ Second, a state statute may simply conflict directly with a federal statute. In such a case, preemption on the basis of

107. Portions of this Section are adapted from Lemley, Shrinkwrap Licenses, supra note 10, at 1270-74.

108. Strictly speaking, federal law preempts state law, not particular private contracts. However, because private contracts are enforced through state law, federal law can and does preempt the enforcement of contracts in appropriate circumstances. For convenience, I will sometimes refer to this as "preemption of contracts," but the reader should be aware that it is really the state enforcement of a contract that is being preempted.

109. Federal preemption of the field may be either express, see, e.g., Jones v. Rath Packing Co., 430 U.S. 519, 532 (1977), or implied from the comprehensive nature of federal regulation in the area, see, e.g., California Fed. Sav. \& Loan Ass'n v. Guerra, 479 U.S. 272, 281 (1987); Rice v. Santa Fe Elevator Corp., 331 U.S. 218, 230 (1947). Federal labor law and ERISA are examples of field preemption. See, e.g., 29 U.S.C. § 157 (1994); 29 U.S.C. § 1144(a) (1994).

Stephen Gardbaum has argued that courts and commentators should distinguish between conflict preemption, which he considers a simple matter of applying Article VI of the United States Constitution, and federal "preemption of the field," which he considers illegitimate. See Stephen A. Gardbaum, The Nature of Preemption, 79 CORNELL L REv. 767, 811 (1994). Courts have distinguished clearly between these two types of preemption but have not been receptive to Gardbaum's argument agamst field preemption. See, e.g, English v. General Elec. Co., 496 U.S. 72, 77 (1990). 
the Supremacy Clause is also straightforward and well-accepted. ${ }^{110}$ Finally, federal law may preempt a state statute with which it does not directly conflict if "the state law stands 'as an obstacle to the accomplishment... of the full purposes and objectives of Congress,"” whether or not Congress intended to preempt the field. ${ }^{111}$ I will refer to these preemption doctrines as "field preemption," "express conflicts preemption," and "implied conflicts preemption" respectively.

\section{Intellectual Property Preemption}

Application of these general preemption rules has proven troublesome in the intellectual property context. ${ }^{12}$ Part of the problem is that the different federal intellectual property statutes have different purposes, and their preemptive scope has been interpreted differently. In this Section, I attempt to parse the rules for intellectual property preemption.

\section{a. Patent Law}

The patent laws themselves do not contain any field preemption provision. Nonetheless, the Supreme Court has held that patent law broadly preempts state statutory protection for unpatentable ideas, or state laws prohibiting the copying of unpatentable industrial designs, on the theory that such laws give the designer the benefits of patent law without forcing her to meet its more stringent requirements. ${ }^{113}$ Both Sears, Roebuck \& Co. v. Stiffel Co. ${ }^{114}$ and Bonito Boats, Inc. v. Thunder Craft Boats, Inc., ${ }^{115}$ are based on an implied structural conflict between the state statutes in question and the purpose of the federal patent statute, which is to provide some protection for inventors while at the same time limiting that protection. ${ }^{116}$ Further, in Graham v. John Deere Co., ${ }^{117}$ the Court held that the Constitution prevented Congress from authorizing "patents whose effects are to remove existent knowledge from the public domain, or to restrict free access to materials readily available."

110. See, e.g., Guerra, 479 U.S. at 281 (1987) (stating that preemption occurs where it is "physically impossible" for a party to comply with both statutes); Florida Lime \& Avocado Growers, Inc. v. Paul, 373 U.S. 132, 143 (1963) (same).

111. Guerra, 479 U.S. at 281 (quoting Hines v. Davidowitz, 312 U.S. 52, 66-67 (1941)).

112. See Dreyfuss, supra note 4, at 238-39 (noting the confusion in federal preemption doctrine).

113. See Bonito Boats, Inc. v. Thunder Craft Boats, Inc., 489 U.S. 141, 164-68 (1989); Compco Corp. v. Day-Brite Lighting, Inc., 376 U.S. 234, 237 (1964); Sears, Roebuck \& Co. v. Stiffel Co., 376 U.S. 225, 228-31 (1964). While some commentators have been critical of this policy, see Douglas Gary Lichtman, The Economics of Innovation: Protecting Unpatentable Goods, 81 MiNN. L. REv. 693, 703-12 (1997); Wiley, supra note 6, it is well-cstablished doctrine.

114. 376 U.S. 225 (1964).

115. 489 U.S. 141 (1989).

116. See Heald, Economics, supra note 6, at 959 (analyzing state statutes in the wake of Bonito Boats).

117. 383 U.S. $1,6(1966)$. 
Combining these two lines of cases, one might reasonably discern a mandatory federal policy that preserves the public domain.

While the Supreme Court has held that federal law broadly preempts state unfair competition statutes that cover patentable subject matter, the Court has also permitted state trade secrecy statutes to coexist with patent law, reasoning that "the patent policy of encouraging invention is not disturbed by the existence of another form of incentive to invention" for patentable (but unpatented) inventions. ${ }^{118}$ As a result, it is not entirely clear how far patent preemption extends, though the Kewanee Court apparently intended to exempt only trade secrets from the general sweep of patent preemption. ${ }^{119}$ The Court has also been inconsistent $\dot{m}$ its treatment of state contract rules governing patent licenses, permitting some contracts that extended idea protection to unpatentable subject nratter ${ }^{120}$ but rejecting other contracts that conflict with federal patent policy. ${ }^{121}$ The result is that it is difficult to predict the precise contours of federal patent preemption.

\section{b. Copyright Law}

There are two basic sets of copyright preemption doctrines. One is based on an express statutory provision partially preenpting the field; the other is based on express and implied conflicts preemption. The field preemption statute is 17 U.S.C. $\$ 301$, which provides that "all legal or equitable rights that are equivalent to any of the exclusive rights within the general scope of copyright ... are governed exclusively by" federal copyright law. ${ }^{122}$ Only state laws that protect subject matter outside the scope of copyright and laws granting "rights that are not

118. Kewanee Oil Co. v. Bicron Corp., 416 U.S. 470, 484 (1974). This reasoning is, on its face, somewhat dubious, given the Court's conclusion in Sears, Compco, and Bonito Boats that state anticopying and design protection statutes do conflict with the federal scheme. See supra note 113. Kewanee might be explained by the long and apparently harmonious coexistence of patent and trade secret law. Kewanee is also based in part on the weakness of state trade secret law. I discuss this in more detail infra note 255 and accompanying text.

119. See Kewanee, 416 U.S. at 481 ("[T]hat which is in the public donain cannot be renoved therefrom by action of the States."). The Kewanee Court cited with evident approval the Court's earlier statentent that "federal law requires that all ideas in general circulation be dedicated to the common good unless they are protected by a valid patent."' Id. (quoting Lear, Inc. v. Adkins, 395 U.S. 653, 668 (1969)) (alteration in original).

120. See Aronson v. Quick Point Pencil Co., 440 U.S. 257, 262-64 (1979) (upholding contract to pay royalty on invention whether or not patcnt was issued). It is debatable whether Aronson really represents a conclusion that contract law can evade federal rules on patentability, since the invention in that case might still have been a trade secret. Thus, one might think of Aronson as a subset of the trade secrets exception to patent preeinption.

121. See, e.g., Lear, Inc. v. Adkins, 395 U.S. 653, 674 (1969) (holding contract estopping licensee from challenging patent validity void under patent law); Brulotte v. Thys Co., 379 U.S. 29, 32-33 (1964) (holding contract extending term of license beyond expiration of patent invalid under patent policy).

122. 17 U.S.C. § 301(a) (1994). 
equivalent to" copyright are saved from this general field preemption. ${ }^{123}$ Thus, the structure of copyright preemption differs from patent preemption. Uncopyrightable works may generally be protected by state law, ${ }^{124}$ but copyrightable works normally cannot be unless the state law right differs significantly from copyright.

Courts interpreting section 301 have added even more subtlety. For example, it is generally accepted that because of the peculiar vagaries of the legislative history of section $301,{ }^{125}$ copyright law does not automatically preempt either trade secrets law or contract law. Rather, those state laws are evaluated on a case-by-case basis to determine whether they impermissibly operate in any given situation to create a state right "equivalent" to copyright. ${ }^{126}$ Furthermore, courts seem to have created a nonstatutory safe harbor under section 301 for state laws adding an "extra element" not explicitly present in the copyright laws. ${ }^{127}$ Contracts have such an "extra element"-the agreement of the parties. ${ }^{128}$ Consequently, some courts have held that contracts that limit the user's rights in the purchased copy of the work (for example, by allowing only certain uses of a copyrighted computer program) are not preempted by section $301 .^{129}$

\section{Id. $\$ 301(\mathrm{~b})(3)$.}

124. The exception occurs when a work falls within the subject matter of copyright but is refused protection because it does not meet the requirements of copyright. The obvious example is works of authorship that don't meet the threshold standard of "originality." See ProCD, Inc. v. Zeidenberg, 86 F.3d 1447, 1453-55 (7th Cir. 1996); Baltimore Orioles, Inc. v. Major League Baseball Players Ass'n, 805 F.2d 663, 668 (7th Cir. 1986).

125. See H.R. 1476, 94th Cong. $\S 301$ (1976). The legislative history of section 301 is a puzzle. See Architeetronics, Inc. v. Control Sys., Inc., 935 F. Supp. 425, 440 (S.D.N.Y. 1996) (stating that the legislative history of seetion 301 "is puzzling and unreliable"); Abrams, supra note 6, at 545 ("Neither Congress nor the Copyright Office seems to have had any conception of what they were doing."). For more detail on the legislative history of 301, see Rice, supra note 7, at 602-04.

126. See, e.g., S.O.S., Inc. v. Payday, Inc., 886 F.2d 1081, 1088 (9th Cir. 1989); Rice, supra note 7, at 604 and cases cited therein; cf. Acorn Structures v. Swantz, 846 F.2d 923 (4th Cir. 1988) (suggesting that breach of promise alone is not necessarily an "extra element" for purposes of section 301).

127. See 1 Melville B. Nimmer \& David Nimmer, Nimmer on Copyright $\S 1.01$ [B], at 1-14, 1-15 (1963) [hereinafter NIMMER ON COPYRIGHT], and cases cited therein.

128. See ProCD, 86 F.3d at 1453-55 and cases cited therein; Architectronics, 935 F. Supp. at 438-41; Brignoli v. Balcb Hardy \& Scheinman, Inc., 645 F. Supp. 1201, 1205 (S.D.N.Y. 1986). But see American Movie Classics Co. v. Turner Entertainment Co., 922 F. Supp. 926, 931 (S.D.N.Y. 1996) (holding that contract claims are preempted under section 301 if they allege nothing more than infringement of plaintiff's copyright rights); Wolff v. Institute of Elec. \& Elecs. Eng'rs., Inc., $768 \mathrm{~F}$. Supp. 66, 69 (S.D.N.Y. 1991) (same); Smith v. Weinstein, 578 F. Supp. 1297, 1307 (S.D.N.Y. 1984) (same), aff d, 738 F.2d 419 (2d Cir. 1984).

129. See ProCD, 86 F.3d at 1454; National Car Rental Sys., Inc. v. Computer Assocs. Int'1, Inc., 991 F.2d 426, 431 (8th Cir. 1993); Frontline Test Equip., Inc. v. Greenleaf Software, lnc., No. 97-00139-C, 1998 U.S. Dist. LEXIS 8259 (W.D. Va. June 3, 1998); Expediters Int'l, Inc. v. Direct Line Cargo Management Servs., Inc., 995 F. Supp. 468, 480-81 (D.N.J. 1998); Architectronics, 935 F. Supp. at 439. This conclusion certainly seems consistent with the "extra element" cases, if not necessarily with the statutory langnage itself. See Ginsburg, Common Law, supra note 39, at 166. One 
The fact that section 301 does not seem to preempt most contractual provisions does not, of course, mean that copyright law never preempts state contract rules. Copyright preemption might also occur because of a conflict between copyright law or policy and state enforcement of a contract. ${ }^{130}$ Sometimes, such a conflict will result from the express terms of the statute. For example, section 203 provides the author with a nonwaivable right to terminate a transfer. ${ }^{131}$ A contractual term that purports to waive this right is simply mconsistent with the

might argue, though, that for courts that redefine "contract" to include standard terms for which there really is no assent, the "extra element" of agreenent of the parties thins to the vanishing point. This is almost certainly true of a case like Hill v. Gateway 2000, Inc., 105 F.3d 1147 (7th Cir. 1997), cert. denied, 118 S. Ct. 47 (1997), in which Judge Easterbrook's analysis effectively read the assent requirement out of contract law entirely. Thus, it would be plausible to argue (contrary to ProCD) that while contracts in general are not preempted by section 301 , shrinkwrap licenses ought to be. $C f$. Vault Corp. v. Quaid Software Ltd., 847 F.2d 255, 270 (5th Cir. 1988) (preempting a state statute validating particular contractual provisions in shrinkwrap licenses).

It is also somewhat troubling that the rationale of ProCD means that contract terms should never be preempted, since they will always contain the "extra element" of agreement between the parties. But the ProCD court itself was unwilling to follow its reasoning that far. See ProCD, 86 F.3d at 1454 (refusing to hold that contracts could never be preempted by copyright).

130. As Maureen O'Rourke says,

In addition to statutory preemption, preemption under the Supremacy Clause of the Constitution must be examined. Even if a particular cause of action survives a $\S 301$ preemption analysis... it still may be preempted if it "stands as an obstacle to the accomplishinent of the full purposes and objectives of Congress."

O'Rourke, supra note 62, at 534; see also Maureen A. O'Rourke, Fencing Cyberspace: Drawing Borders in a Virtual World, 82 MiNN. L. REv. 609, 694 (1998) [hereinafter O'Rourke, Fencing Cyberspace]; Cohen, supra note 11, at 23. For the fundamental statement of Supremacy Clause copyright preemption, see Goldstem v. California, 412 U.S. 546, 559 (1973). In Goldstein, the Court distinguished three types of situations: (1) areas in which federal law mandated protection; (2) areas in which federal law mandated no protection; and (3) areas in which federal law was silent. See id. Only in the last category of cases was state law free to operate:

Where the need for free and unrestricted distribution of a writing is thought to be required by the national interest, the Copyright Clause and the Commerce Clause would allow Congress to eschew all protection. In such cases, a conflict would develop if a State attempted to protect that which Congress intended to be free from restraint or to free that which Congress had protected.

Id. One might perhaps object that the existence of partial field preemption in section 301 necessarily means that state law outside the reach of section 301 is not preempted. Cf. Cipollone v. Liggett Group, Inc., 505 U.S. 504, 517 (1992) (drawing such an inference in another statute). More recently, the Court has wisely rejected Cipollone's interpretive canon, at least as an absolute rule. See Freightliner Corp. v. Myrick, 514 U.S. 280 (1995) (finding that preemption can be based on implied conflicts even in cases in which there is both express partial field preemption and a "savings clause" protecting state law).

A moment's reflection will demonstrate that section 301 cannot be all there is to copyright preemption. Section 301 is an extremely narrow "field preemption" statute; in particular, it would not preempt state laws that run directly counter to the federal statute because they would not be "equivalent" to copyright. For example, suppose California passed a law stating that the copyright laws could not be enforced against any citizen of California. Section 301 would not preempt such a law because it isn't "equivalent" to copyright. But the Supremacy Clause surely would preempt the law because it conflicts with the federal scheme.

131. See 17 U.S.C. $\S \S 203(a)(3),(5)$ (1994); see also id. $\S 304(c)(5)$ (providing a similar right during the extended term of works created before 1978). 
statute; even if state contract law would otherwise enforce it, federal law will preempt such enforcement. ${ }^{132}$ By contrast, some provisions of the Copyright Act expressly provide that they may be waived or altered by contract. ${ }^{133}$ For these provisions, there presumably would be no conflict between copyright law and the contractual term.

Unfortunately, most copyright provisions offer no guidance in either direction. For these provisions, courts must define the parameters of implied conflicts preemption. This involves an attempt to figure out whether each particular provision in the Copyright Act is merely a default rule that the parties are free to ignore, or whether it instead reflects a part of the balance of interests in federal policy that should not be upset. Copyright is not a system of absolute property rights. It is " a scheine of carefully balanced property rights that give authors and their publishers sufficient inducements to produce and disseminate original creative works and, at the same time, allow others to draw on these works in their own creative and educational activities." 134 Conflicts-based preemption of contracts will occur not only in cases in which there is a direct conflict with the express terms of the statute, but also in cases in which a state law stands as an obstacle to achieving the general goals of federal law because it upsets the balance struck by Congress. ${ }^{135}$

132. Cf. Crow v. Wainwright, 720 F.2d 1224, 1226 n.2 (11th Cir. 1983) (stating that Supremacy Clause voids state actions contrary to federal copyright authority).

133. See 17 U.S.C. $\$ 113$ (d) (1994) (providing for one set of rules regarding moral rights if thc author consents in writing to alteration, and another if the author does not); see also H.R. 94-1476, 94th Cong. (1976) (providing that the parties may contract around the first sale doctrine in 17 U.S.C. $\S$ 109(a) (1994), but limiting the copyright owner to contract rather than copyright remedies if they do so). The first sale-contract question appears to be more difficult than the legislative history suggests. In Bobbs-Merrill Co.v. Straus, 210 U.S. 339, 349-51 (1908), the Court held that a publisher could not mclude terms on a book and thereby bind subsequent purchasers and resellers to those terms. The Court viewed the question as purely one of construing the Copyright Act, which did not give the copyright owner control over subsequent sales of the book. See id. at 350. The Court expressly reserved the question of whether a contract directly between the copyright owner and the subsequent purchaser would be effective-though the Court clearly did not consider the legend on the book as enough to create such a contract. See id.

Nimety years later, in Quality King Distributors v. L'Anza Research International, 118 S. Ct. 1125, 1130 (1998), the Court held that the copyright first sale doctrine permitted purchasers of a produet made in the United States for shipment abroad to reimport it and resell it in the United States. The Court relied on Bobbs-Merrill to reach this result. See id. at 1128-30. But in so doing, it noted "the critical distinction between statutory rights and contract rights." Id. at 1129 . While the Court did not elaborate, one might infer that the Court would have permitted a breach of contract action to proceed in these circuinstances even though the statute did not support an aetion for copyright infringement.

134. 1 Paul Goldstein, Copyright 1:40 (2d ed. 1998).

135. See Califorma Fed. Sav. \& Loan Ass'n v. Guerra, 479 U.S. 272, 281 (1987); see also Burbank v. Lockheed Air Terminal, Ine., 411 U.S. 624, 638-39 (1973) (discussing this balance preemption). 


\section{c. Applying Preemption to Contract Law}

Courts considering Supremacy Clause preemption of contract terms have reached different results in different cases. A number of courts have preempted contracts under both patent law and copyright law. ${ }^{136}$ Other courts have refused to preempt contract terms asserted to be at odds with the copyright or patent statutes. ${ }^{137}$ And one recent decision even ignored the question of conflicts preemption entirely, although it was clearly necessary to the resolution of the dispute before it! $!^{138}$

Commentators can try to construct general algorithms for explaining these decisions and determining when a contract term will be

136. See, e.g., Lear, Inc. v. Adkins, 395 U.S. 653, 674 (1969); Brulotte v. Thys Co., 379 U.S. 29, 32-33 (1964); Wright v. Warner Books, Inc., 953 F.2d 731, 741 (2d Cir. 1991) (finding that a broad construction of a book hicense restriction would conflict with fair use doctrine); S.O.S., Inc. v. Payday, Inc., 886 F.2d 1081, 1088 (9th Cir. 1989); Vault Corp. v. Quaid Software Ltd., 847 F.2d 255, 270 (5th Cir. 1988) (preempting state statute that attempted to validate contract); Saturday Evening Post Co. v. Rumbleseat Press, Inc., 816 F.2d 1191, 1199-1200 (7th Cir. 1987) (refusing to enforce an agreement by a licensee not to challenge the copyrightability of the licensed work); RCA Mfg. Co., Inc. v. Whiteman, 114 F.2d 86, 88 (2d Cir. 1940) (holding that a vendor of records could not preclude their public performance over the radio by attaching a contract to the records themselves); Markogianis v. Burger King Corp., 42 U.S.P.Q.2d 1862, 1865 (S.D.N.Y. 1997) (holding that a claim for implied contract to protect ideas is preempted where no relationship of secrecy existed); American Movie Classics Co. v. Turner Entertainment Co., 922 F. Supp. 926, 930-31 (S.D.N.Y. 1996); Wolff v. Institute of Elec. \& Elecs. Eng'rs., Inc., 768 F. Supp. 66, 69 (S.D.N.Y. 1991); Tannock v. Review Trading Corp., Inc., 231 U.S.P.Q. 798, 801-02 (D.N.J. 1986); Smith v. Weinstem, 578 F. Supp. 1297, 1309 (S.D.N.Y. 1984); cf. Long v. Quality Computers \& Applications, Inc., 860 F. Supp. 191, 197 (M.D. Pa. 1994) (fimding a claim for interference with contract through copyright infringement preempted by the Copyright Act).

For a treatment of the issue that endorses contract preemption in limited circumstances, imcluding shrinkwrap licenses, see NIMMER on COPYRIGHT, supra note 127, at 1-19 to 1-20. For discussions of patent preemption of software contract terms limiting reverse engineering, see Charles R. McManis, Intellectual Property Protection and Reverse Engineering of Computer Programs in the United States and the European Community, 8 HIGH TECrr. L.J. 25, 94 (1993); Rice, supra note 7, at 577-91; Mark I. Koffsky, Note, Patent Preemption of Computer Software Contracts Restricting Reverse Engineering: The Last Stand?, 95 CoLuM. L Rev. 1160 (1995).

137. See, e.g., Aronson v. Quick Point Pencil Co., 440 U.S. 257, 266 (1979) (patent law); Studiengesellschaft Kohle M.B.H. v. Shell Oil Co., 112 F.3d 1561, 1568 (Fed. Cir. 1997) (patent law); National Car Rental Sys., Inc. v. Computer Assocs. Int'1, Inc., 991 F.2d 426, 431 (8th Cir. 1993) (finding that copyright law does not preeinpt contract term); Architectronics, Inc. v. Control Sys., Inc., 935 F. Supp. 425,440 (S.D.N.Y. 1996) (copyright law).

138. See ProCD, Inc. v. Zeidenberg, 86 F.3d 1447 (7th Cir. 1996) (considering preemption only under section 301). There is simply no arguable justification for the court's refusal even to discuss conflicts preemption in the case before it. The issue was briefed, and because the court enforced the contract, it must necessarily have concluded that enforcentent of the contract was not preempted.

In the interest of full disclosure, I should note that I authored an amicus brief in the ProCD case on behalf of the American Committee for Interoperable Systems-on the issue of conflicts preemption, no less. See Brief of Amicus Curiae of American Committee for Intcroperable Systems in support of Appellees (visited Oct. 26, 1998) <http://www.complaw.com/lawlibrary/brief.html>. Since I did it pro bono, however, I can be accused at most of sour grapes, not actual bias, in criticizing Judge Easterbrook's decision. 
preempted. ${ }^{139}$ For example, one might perhaps draw a reasonable distinction between cases $m$ which a copyright owner licenses less than her entire bundle of rights to a licensee under terms consistent with the copyright laws, ${ }^{140}$ and cases in which the copyright owner licenses some or all rights to a licensee only on the condition that the licensee give up other rights granted him by the copyright laws. ${ }^{141}$ More likely, though, courts in the post-Article $2 \mathrm{~B}$ world will muddle through, and consider contract preemption on a case-by-case basis. ${ }^{142}$ It is extremely unlikely that any court will ever hold that the "field" of contract law-or even the slightly more manageable "field" of contracts governing intellectual property rights ${ }^{143}$-is entirely preempted by federal intellectual property law. The field is too broad, and the role of state contract law in interpreting licensing agreements is too well accepted. On the other hand, enforcement of certain contracts will continue to be preempted, and I suspect that preemption will occur with greater frequency as Article $2 \mathrm{~B}$ increases the power and scope of contracts.

\section{B. The Limits of Preemption}

Preemption analysis is an important and integral part of federal intellectual property law. Indeed, it is likely to become much more important as the growth of state intellectual property rights continues. ${ }^{144}$

139. For some efforts at doing so, see Ginsburg, Common Law, supra note 39, at 168-71; Karjala, supra note 7, at 521-25 (distinguishing between commercialized and uncommercialized works); O'Rourke, Copyright Preemption, supra note 9, at 53 (applying a hypothetical fair use inquiry). O'Rourke's other work can be read as generally rejecting preemption even in fair use cases with certain very narrow exceptions. See O'Rourke, Fencing Cyberspace, supra note 62, at 479.

140. This would arguably encompass National Car Rental Sys., Inc. v. Computer Assoc. Int'l, Inc., 991 F.2d 426, 429-30 (8th Cir. 1993), in which the copyright owner licensed the program only for in-house use). For an argument in favor of a similar distinction, see Covotta \& Sergeef, supra note 20 , at $50-51$.

141. This encompasses cases such as Vault, 847 F.2d 255 (5th Cir. 1988), and Brilotte, 379 U.S. 29 (1964), in which intelleetual property owners unsuccessfully attempted by contract to "opt out" of rights granted by statute to their licensees.

142. See Paul Heald, Resolving Priority Disputes in Intellectual Property Collateral, 1 J. INTELL. Prop. L. 135, 136 (1993) ("The key [to preemption analysis] is not to examine preemption questions in the abstract, but to identify the precise disputes that federal law settles and leave for state law the disputes for which federal law provides no answer.").

143. As an aside, the reader will note that this phrase is necessarily imprecise. Even determining what contracts are within the "field" of intellectual property is a Herculean task. The field could be as narrow as "licenses of intellectual property rights," a term which is itself open to interpretation but which may not mclude many shrinkwrap licenses or collateral agreements such as the one in Aronson. Or it inay be as broad as to include all contracts relating to ideas, intangibles, or intellectual property, encompassing confidentiality agreements, employment agreements, and numerous contracts for the sale of physical goods. Not incidentally, a similar problem has dogged the scope, or coverage, provisions of Article 2B. See supra note 12; cf. Dreyfuss, supra note 4, at 209-12 (discussing the coverage provisions of Article 2B).

144. The right of publicity, a state law which grants individuals control over the use of their name or likeness for commercial purposes, is one obvious example of a state law that presents potential conflicts with federal intellectual property policy. See White v. Samsung Elecs. Am., Inc., 
But there are a number of reasons why preemption, although necessary, is not sufficient to protect the interests of intellectual property law in the indifferent world of contract. In this Section, I offer several such reasons.

\section{Preemption Lacks Nuance}

Using preemption doctrine against contracts is something like swinging a sledgehammer at a gnat: you are likely to hit the target, but you may do some serious damage to the things around it. More likely though, and of more immediate concern for my purposes, you might decide not to swing the hammer at all, for fear of hitting the wrong thing. Field preemption doctrine (of the sort evident in section 301 of the Copyright Act) has failed utterly to deal with contract law, and for precisely this reason: courts don't want to preempt the entire field of licensing contracts, and preemption doctrine does not always give them tools fine enough for the delicate legal surgery they must perform. ${ }^{145}$ Conflicts preemption holds more promise because it can be directed at the state enforcement of particular contract terms. ${ }^{146}$ But it still seems like an awfully big hammer. And indeed there are courts that have refused to apply preeinption at all to contract law for this reason, even when the federal policies seem to point strongly in favor of preemption. ${ }^{147}$ This lack of nuance will render preemption meffective if it causes courts to shy away from applying it altogether.

\section{Intellectual Property Rules Aren't Always Statutory}

The case for conflicts preemption seeins quite clear when a contract term contravenes a federal statute. If the parties agree to do something

989 F.2d 1512 (9th Cir. 1993) (Kozinski, J., dissenting from derial of rehearing en banc) (discussing conflicts between federal law and the right of publicity); Paul J. Heald, Filling Two Gaps in the Restatement (Third) of Unfair Competition: Mixed-Use Trademarks and the Problem with Vanna, 47 S.C. L. REv. 783, 804-08 (1996). Dilution is another. See Heald, Unfair Competition, supra note 6, at 1413-14, 1436; David S. Welkowitz, Preemption, Extraterritoriality, and the Problem of State Antidilution Laws, 67 TuL. L. REv. 1, 7-45 (1992).

145. See Reichman \& Franklin, supra note 8, at 28 (" $[T]$ he preemption doctrine tends naturally to paint with a broad brusli that validates or invalidates whole classes of contracts."). David Rice notes that preemption challenges "are to be avoided, not tempted." Rice, supra note 7, at 648; see also O'Rourke, supra note 62, at 541 (recommending "a more nuanced analysis that places the Copyright Act within the context of other federal law..."). O'Rourke's specific proposal is to expand the treatment of antitrust law rather than to rely on preemption doctrine. See O'Rourke, supra note 62, at 545. One can question whether antitrust really is more nuanced than copyright policy for this purpose. See, e.g., David McGowan, Free Contracting, Fair Competition, and Draft Article 2B: Some Reflections on Federal Competition Policy, Information Transactions, and "Aggressive Neutrality," 13 BERKELEY TECH. L.J. (forthcoming Dec. 1998) (manuscript at 49, on file with author).

146. See Vault Corp. v. Quaid Software Ltd., 847 F.2d 255, 270 (5th Cir. 1988) (invalidating provisions in a licensing agreeinent that prohibited decompilation of a computer program and preempting state law that endorsed such provisions).

147. See infra notes $154-156$ and accompanying text. 
that the federal statute says they simply can't do-such as transfer moral rights or preclude termination of an mitial copyright transfer ${ }^{148}$ it is quite easy to conclude that the contract can't be enforced. The case is a little tougher if the federal statute establishes a clear federal policy, but doesn't discuss the possibility of contracting around its rule. For example, a contract term that says "licensee agrees never to make fair use of the licensed work" clearly contradicts a federal statute, ${ }^{149}$ but courts might struggle a bit with whether the contract ought to be preempted or whether the parties are merely agreeing to opt out of a default rule. Courts might struggle even more when the federal policy is nowhere expressed in the statute but is implied from the general "balance between the artist's right ... and the public's need for access." 150 There may be strong economic and policy reasons to conclude that a particular doctrine is not merely a default rule, as there are in the case of fair use. ${ }^{151}$ But the detailed policy evaluation such a case would require may be ill-suited to the traditional outlines of preemption, which are based on general concepts of legislative intent. Courts may be reluctant to preempt contract terms except in the clearest cases of conflict, further reducing the effectiveness of preemption.

\section{Intellectual Property Rules Aren't Always Federal}

One very important limitation of federal preemption is that it is federal. Because it is based on the core notion that state law can't override federal law, preemption simply will not protect state intellectual property rules against intrusion by contract. Thus, if state trade secrets law seeks to limit or void contractual provisions, we must look elsewhere for the grounds.

But this is not just a problem for trade secrets law. Common law copyright, idea protection, right of publicity, artists' moral rights, and trademark dilution are all state intellectual property doctrines that contain their own particular set of policy choices. These policies may also be avoided or set at naught by Article 2B's contract regime. ${ }^{152}$ Preemption can't address these issues.

148. See supra notes 74-75 and accompanying text.

149. See 17 U.S.C. \& 107 (1994) (providing a fair use right).

150. Stewart v. Abend, 495 U.S. 207, 228 (1990).

151. See, e.g., Karjala, supra note 7, at 520; Lemley, Economics of Improvement, supra note 10, at 1042-83; Litman, supra note 4; Rice, supra note 7, at 556--70.

152. Of particular note here are state artists' moral rights statutes that preclude waiver or transfer of the right. See, e.g., N.Y. ARTs \& CuLT. AFF. LAw $\$ 14.03$ (McKinney 1998); Morseburg v. Balyon, 621 F.2d 972, 978 (9th Cir. 1980) (interpreting the California Resale Royalty Act).

A separate set of issues is presented in cases in which Article $2 \mathrm{~B}$ expressly alters existing state law in a particular context. An example is idea protection rules, which section 2B-206 of Article 2B would now govern. See U.C.C. \$ 2B-206 (Draft, Aug. 1, 1998). If a state enacts a statute specifically changing an existing state legal rule, rather than simply passes a general contract law, the new 


\section{4. "Contracts Are Different"}

A few courts and commentators have taken the position that federal preemption simply shouldn't apply to contract terms-or at least that it shouldn't apply in the same way-because contracts are different than state statutes ${ }^{153}$ The basic argument here (adopted by Article 2B's drafters) is usually that "as both a practical and a conceptual matter, copyright (or patent) do not generally preempt contract law.... A contract defines rights between parties to the agreement, while a property right creates rights against all the world. They are not equivalent."154 Judge Easterbrook's decision in ProCD v. Zeidenberg seems to accept this view, ${ }^{155}$ and some courts have taken this logic so far as to conclude that contracts simply can't be preempted by copyright law. ${ }^{156}$

There are a number of problems with the "contracts are different" idea. First, the reference to "equivalence" seems to direct the analysis only at copyright field preemption under section 301 , and thus to ignore both copyright conflicts preemption and any form of patent preemption. ${ }^{157}$ Even if contract and copyright are not equivalent, it simply does not follow that federal law places no limits on the enforceability of contracts. Courts that take this position should also be troubled by the

provision will presumably take precedence over the old law. Even then, though, one should perhaps be worried on policy grounds about the provisions being "snuck into" a general contract statute most legislators will never read. Cf. Jonathan R. Macey, The Transformation of the American Law Institute, 61 GEo. WASH. L. REv. 1212, 1214-15 (1993) (discussing the dangers of "capture" of the uniform state law process); Kathleen Patchel, Interest Group Politics, Federalism, and the Uniform Law Process: Some Lessons from the Uniform Commercial Code, 78 MinN. L. Rev. 83, 126-38 (1993) (same); Larry E. Ribstein \& Bruce H. Kobayashi, An Economic Analysis of Uniform State Laws, $25 \mathrm{~J}$. Legal Stud. 131, 184 (1996) (same); Alan Schwartz \& Robert E. Scott, The Political Economy of Private Legislatures, 143 U. PA. L. REv. 595, 644 (1995) (same).

153. See infra notes $154-156$ and accompanying text.

154. U.C.C. art. 2B Preface (Draft, Aug. 1, 1998) (emphasis in original).

155. See ProCD, Inc. v. Zeidenberg, 86 F.3d 1447, 1455 (7th Cir. 1996) ("[W] hether a particular license is generous or restrictive, a simple two-party contract is not 'equivalent to any of the exclusive rights within the general scope of copyright' and therefore may be enforced.") (quoting 17 U.S.C. $\S 301$ ); accord Lattie v. Murdach, 42 U.S.P.Q.2d 1240, 1244 (N.D. Cal. 1997); see also Warlick, supra note 4, at 168-69 (noting but criticizing this approach).

156. See Architectronics, Inc. v. Control Sys., Inc., 935 F. Supp. 425, $438-41$ (S.D.N.Y. 1996). But see Jaccard, supra note 20, at 647. Though sympathetic to this argument, Jaccard notes that the rights conveyed by contract may be "eqnivalent" to copyright even though contract law has different elements. See id.

The district court in P.C. Films Corp. v. Turner Entertainment Co., 954 F. Supp. 711, 715 (S.D.N.Y. 1997), concluded that an agreement to bind a licensee beyond the expiration of the copyright was enforceable because it was "merely a contract between two private parties." The Second Circuit rejected this approach in dictum, though it concluded it did not need to resolve the issue of whether restrictions on licensees could survive the expiration of copyright. See P.C. Films Corp. v. MGM/UA Home Video Inc., 138 F.3d 453, 458 (2d Cir. 1998) ("We are not convinced that this analysis gives sufficient weight to federal copyright law and the constitutional primciple that a grant of copyright rights can be for 'limited Times' only.").

157. As noted above, the decision in ProCD is certainly guilty of this error. See supra note 138 and accompanying text. 
significant number of cases that $d o$ apply intellectual property rules to preempt contracts. ${ }^{158}$

Second, the viability of the distinction between private contracts and public legislation is diminishing day by day. One of the main changes Article 2B would make in current law would be to render enforceable contract "terms" to which the parties did not agree in the classic sense, and indeed of which one party may be entirely unaware. ${ }^{159}$ Article 2B would also enable the enforcement of such contract terms "downstream"-that is, against whomever later acquires the software ${ }^{160}$-despite the fact that a first sale under both patent and copyright law would free the purchaser from upstream contractual restrictions. Technology facilitates this change by allowing a vendor to interpose contract terms even in a downstream transaction that would not ordinarily be thought to demonstrate privity between the "contracting" parties. ${ }^{161}$ And Congress has just enacted federal legislation that may lock in these contractual terms, making it a crime to alter or remove them. ${ }^{162}$

In other words, Article 2B promises to usher in an era of "private legislation," in which parties who are in a position to write contracts can jointly impose uniform terms that no one can escape. ${ }^{163}$ Some might think this a good thing; ${ }^{164}$ but good or bad, it looks as much like the creation of "rights against the world" as it does an agreement between two private parties. ${ }^{165}$ Indeed, since one must necessarily have access to a

158. See supra note 136 (collecting cases).

159. See, e.g., U.C.C. § 2B-208 (Draft, Aug. 1, 1998); see also Lemley, Shrinkwrap Licenses, supra note 10 , at $1262-63$ (noting and criticizing this change).

160. See U.C.C. \& 2B-507(a)(2) (Draft, Aug. 1, 1998) (providing that transferees take subject to the terms of the license); id. $\S 2 \mathrm{~B}-502(2)$ (providing that transfcrs of a license that violate the contractual terms are ineffective). For a discussion of these provisions, see Dreyfuss, supra note 4 , at 226-32.

161. For a discussion of some of these technological developments, see Cohen, supra note 4; Julie E. Cohen, A Right to Read Anonymously: A Closer Look at Copyright Managentent in Cyberspace, 28 ConN. L. REv. 981 (1996); Elkin-Koren, Copyright Policy, supra note 11, at 104.

162. See Digital Millennium Copyright Act, H.R. 2281, 105th Cong. (1997); S. 2037, 105th Cong. (1998).

163. Robert Merges has noted this phenomenon and suggested that shrinkwrap license terms should be preempted when there is sufficient uniformity in the industry that the terms in effect amount to "private legislation" by software vendors. See Merges, supra note 1, at 1612. Merges relies on Professor Kessler's earlier work, which suggests that when contracts of adhesion were standardized throughout an industry, depriving consumers of meaningful clioice, freedom of contract had in effcct been replaced with private legislation. See Friedrick Kessler, Contracts of Adhesion-Some Thoughts About Freedom of Contract, 43 Colum. L. REv. 629 (1943); Mergcs, supra note 1, at 1611-12; see also Elkin-Koren, Contracts in Cyberspace, supra note 11, at 40 (suggesting that uniform contractual terms are of concem even when they do not confer market power); Mark Gimbel, Note, Some Thoughts on the Implications of Trusted Systems for Intellectual Property Law, 50 STAN. L. REv. 1671, 1683-84 (1998).

164. See Frank H. Easterbrook, Cyberspace and the Law of the Horse, 1996 U. CHl. Legal F. 205.

165. See Elkin-Koren, Copyright Policy, supra note 11, at 103-04; O'Rourke, Fencing Cyberspace, supra note 130, at 693 (noting that on-line agreements would bind all comers, and 
work to make any use of it, a contract premised on access could presumably be imposed in every case. If a boatmaker wants to get the same rights the Florida boat hull statute would have provided in Bonito Boats, ${ }^{166}$ all she needs to do is affix a copy of the statute to the boat hull itself. Under Article 2B, the statute will become an enforceable contract if the contract provides that use or analysis of the hull constitutes acceptance. ${ }^{167}$ Why this should be more palatable to the Court than the statute itself is not clear.

Third, even truly "private" contracts affect third parties who haven't agreed to the contract terms. Many contracts have significant negative externalities. ${ }^{168}$ While Tom Bell correctly observes that we don't refuse to enforce all contracts just because they inay have effects on others, ${ }^{169}$ neither should we ignore these external effects. Various contractual provisions may be held invalid on a variety of public policy grounds, even under state law. ${ }^{170}$ Indeed, Terry Fisher has called such public policy restrictions on contractual freedom "ubiquitous." 171 And with respect to at least some intellectual property contracts, there are strong public policy reasons to limit the freedom to contract. ${ }^{172}$

Even if the difference between contracts and public law proves illusory, one might perhaps substantiate the difference by allowing copyright owners to "opt out" of copyright entirely, relying solely on

therefore look more like property rights held against the world). Ginsburg acknowledges this point: " $[\mathrm{T}] \mathrm{n}$ a world of mass-market, click-on licenses, there are few strangers to the contract. The classic distinction between a contract right inter partes and a property right erga omnes dissolves ...." Ginsburg, Common Law, supra note 39, at 167.

166. Bonito Boats, Inc., v. Thunder-Craft Boats, Inc., 489 U.S. 141 (1989) (invalidating Florida statute that precluded copying unpatented boat hull designs).

167. See U.C.C. $\S \S 2 B-111$ (a) (Draft, Aug. 1, 1998).

168. The most thorough development of this point to date is Cohen, supra note 11. See also ElkinKoren, Copyright Policy, supra note 11, at 107-13; Lemley, Economics of Improvement, supra note 10, at 1057-58; Lydia Pallas Loren, Redefining the Market Failure Approach to Fair Use in an Era of Copyright Permission Systems, 5 J. INTELl. PROP. L. 1, 6 (1997); McGowan, supra note 145. Even some commentators who generally would enforce shrinkwrap licenses are troubled by ProCD's failure to acknowledge these external effects. See O'Rourke, Copyright Preemption, supra note 9, at 83-84; Finkelstein \& Wyatt, supra note 20 , at 856.

169. Bell, supra note 11, at $588 \mathrm{n} .156$ (responding to my argument that contract terms create externalities).

170. See infra Part III.B.

171. See Williain W. Fisher III, Compulsory Terms in Internet-Related Contracts, 73 CHI.-KENT L. REv. (forthcoming 1998) (listing implied warranties of merchantability, implied warranties of habitability im residential leaseholds, rent control, minimum wage laws, unaximum hours legislation, bans on child labor, compulsory terms in insurance policies, manufacturers' strict liability, protection for inortgagees and the occupants of migrant labor camps as examples of legal restrictions on contractual freedom); see also Michael J. Trebilcock, The Lmits of Freedom of ConTRact 58 (1993) ("The problem of third-party effects from exchange relationships is pervasive and not abberational.").

172. See infra Part III.B; see also Lemley, Economics of Improvement, supra note 10 , at 1057-58 (discussing the externalities imposed by contractual restrictions on potential reusers of a work). 
contractual protection. Tom Bell has argued for this approach. ${ }^{173}$ Until recently, copyright owners would probably have found this an unattractive alternative, precisely because there were some types of conduct that copyright could reach but contract could not, and because the remedies for copyright infringement were so much stronger. The proposed expansion of contract in Article 2B to allow it to reach third parties not in privity with the vendor in any meaningful sense, coupled with the ability of vendors to write alinost any reinedy they wish into the contract, may make those differences disappear. Indeed, the possibility that intellectual property owners can get consequential and punitive damages, injunctive relief, extrajudicial self-help, and technological protection without having to meet any of the substantive requirements of intellectual property law, simply by contracting for it, might prove quite attractive to them.

The very fact that contract law will be augmented by Article $2 \mathrm{~B}$ to give it the character and power of public legislation suggests that even in an "opt-out" scheme, contracts are not really "different" for preemption purposes. But in fact the problein with Article $2 B$ is worse. Article $2 \mathrm{~B}$ is not an opt-out statute. Rather, it permits intellectual property owners to pick and choose a combination of copyright and contractual rules and remedies. By adding its contract-enforcement regine to existing federal intellectual property rights, Article $2 \mathrm{~B}$ distorts the balance that exists with contract alone. ${ }^{174}$

In short, there are a number of problems with assuming that contracts are different than public law. Courts that adopt this approach may be in error. Nonetheless, the fact that soine courts labor under this misapprehension further limits the effectiveness of federal preemption law because it inclines those courts to assume that intellectual property preemption doesn't apply to contracts. ${ }^{175}$

\section{Conclusions}

By emphasizing the limits of preemption, I certainly don't mean to suggest that preemption of contract provisions will not occur, or that it should not occur. ${ }^{176}$ Rather, my concern is that for a combination of reasons, good and bad, courts may not use contract preemption to solve all of the problems that unrestrained enforcement of contracts would create for intellectual property law. The gap that remains will have to be filled

173. See Bell, supra note 11, at 615-16. Ray Nimmer also suggests that "copyright law will recede in importance," displaced in part by contract. Nimmer, supra note 4, at 1 .

174. See McManis, supra note 14, at 176; Nimmer et al., supra note 8, at 22-23.

175. See Nimmer et al., supra note 8 , at 22-23 ("Although attempts at altering the delicate balance struck by copyright law should fail under the doctrine of preemption, . . . courts sometimes fail to appreciate the preemptive force of copyright [in contract cases.]").

176. For a number of examples in which preemption should occur, see id. at 64-68. 
by a number of other intellectual property doctrines. ${ }^{177}$ In Part III, I take a look at a few of those doctrines.

\section{III \\ Public Policy Restrictions on Information Contracts}

Even if federal law does not preempt enforcenent of a specific contract term directly, the law may still restrict enforcement of that term on public policy grounds. ${ }^{178}$ Public policy limitations on contractual freedom are fairly common in our society. Article 2B itself acknowledges one such limitation-the contract doctrine of unconscionability. ${ }^{179}$ Certain shrinkwrap license terms-such as those featured in a recent Dilbert cartoon ${ }^{180}-$ may well be held unconscionable. But unconscionability is rarely used, ${ }^{181}$ and it is not well-tailored to the needs of intellectual property law. In the intellectual property context, three sets of rules may suppleinent contract preemption: copyright misuse, federal public policy, and state public policy. Not all of these rules will apply in every case; there will still be plenty of room for contract law to operate. But its operation will not be unfettered by intellectual property policy. In this Part, I explain these three sets of rules and consider the limits they impose on contract terms.

\section{A. Copyright Misuse}

The doctrine of copyright misuse renders a copyright unenforceable if the copyright owner has engaged in certain sorts of misconduct in licensing or enforcing the copyright. ${ }^{182}$ Copyright misuse is of relatively recent vintage. While the somewhat analogous doctrine of patent

177. See Madison, supra note 20, at $18 \mathrm{n} .69$ ("That federal preemption doctrine will be an important legal battleground ... seems clear as a doctrinal matter, at least under current law, but focusing on that debate casts the issue in terms that are unlikely to give arguments on behalf of the 'public' interest the complete airing that they deserve.").

178. Merges notes that preemption and misuse doctrines constitute two separate tiers of "policing" supporting the intellectual property rules. See Merges, supra note 1, at 1613; see also Jaccard, supra note 20, at 649 (agreeing with Merges).

179. See U.C.C. \$ 2B-110 (Draft, Aug. 1, 1998).

180. In the cartoon, Dilbert madvertently agrees to "spend the rest of my hife as a towel boy in Bill Gates' new mansion" when he opens a piece of shrinkwrapped software without reading the entire agreement first (on file with author, pasted to his office door).

181. See Forsythe v. BancBoston Mortage Corp., 135 F.3d 1069, 1074 (6th Cir. 1997) (noting that the doctrine of unconscionability is used only in rare instances). For a general discussion of unconscionability, see Arthur Allen Leff, Unconscionability and the Code-The Emperor's New Clause, 115 U. PA. L. REv, 485, 487 (1967). For a discussion of unconscionability in the context of shrinkwrap heenses, see Lemley, Shrinkwrap Licenses, supra note 10, at 1254-55. On the economics of the doctrine, see Richard Craswell, Property Rules and Liability Rules in Unconscionability and Related Doctrines, 60 U. CH. L. Rev. 1 (1993).

182. See 2 GoLDSTEIN, supra note 134, at 9:35-40. 
misuse has been around for a century, ${ }^{183}$ courts in this century generally denied the existence of a copyright misuse defense. ${ }^{184}$ Before 1990 , only a handful of district courts had granted relief based on such a defense, ${ }^{185}$ though others had acknowledged that the defense was available in appropriate circumstances. ${ }^{186}$ Since 1990 , several cases have found plaintiffs' copyrights unenforceable for misuse. ${ }^{187}$ The circumstances in which they have done so are instructive for contractual restrictions on the use of copyrighted works.

In the context of patent misuse, there has been a long-standing debate over whether the misuse defense should be available only in circunistances in which the patentee has violated the antitrust laws. ${ }^{188}$ Patent misuse case law is largely, but not entirely, coextensive with antitrust doctrine; certain conduct can constitute patent misuse but does not violate the antitrust laws. ${ }^{189}$

183. For a history of the patent misuse doctrine, see 3 Donald S. Chisum, Chisum on PATENTS \$ 19.04 (1998).

184. See 2 GoLDSTEIN, supra note 134, at 9:35-36 (citing cases). Goldstein notes, however, that the cases expressing skepticism about the copyright misuse defense "should be taken with a grain of salt" because they are generally older cases, and the recent trend seems to be to recognize the defense. Id.

185. See M. Witmark \& Sons v. Jensen, 80 F. Supp. 843, 850 (D. Minn. 1948); see also Vogue Ring Creations, Inc. v. Hardman, 410 F. Supp. 609, 615-16 (D.R.I. 1976) (finding copyright misuse in an altemative holding that might be considered dictum); $c f$. CBS v. American Soc'y of Composers, Authors \& Publishers, 562 F.2d 130, 141 n.29 (2d Cir. 1977) (finding habihity for copyright misuse), $r e v ' d, 441$ U.S. 1, 24 (1978) (remanding the case under a different legal standard).

186. See, e.g., F.E.L. Publications, Ltd. v. Catholic Bishop, 214 U.S.P.Q. 409, 413 n.9 (7th Cir. 1982) (suggesting that application of the misuse defense requires a balancing of factors); Blendingwell Music, Inc. v. Moor-Law, Inc., 612 F. Supp. 474, 483 (D. Del. 1985); Broadcast Music, Inc. v. Moor-Law, Inc., 203 U.S.P.Q. 487, 488 (D. Del. 1978); see also 2 GoldsTEIN, supra note 134, at 9:37-38 n. 12 .

187. See, e.g., DSC Communications Corp. v. DGI Techs., Inc., 81 F.3d 597, 601 (5th Cir. 1996); Lasercomb Am. v. Reynolds, 911 F.2d 970, 979 (4th Cir. 1990); qad. inc. v. ALN Assoc., 770 F. Supp. 1261, 1266-69 (N.D. Ill. 1991), aff d, 974 F.2d 834 (1992).

188. See USM Corp. v. SPS Tech., Inc., 694 F.2d 505, 512 (7th Cir. 1982) (discussing whether patent misuse should be coextensive with antitust law); PHILLIP AREEDA \& LouIS KAPLOw, ANTITRUST ANALYSIS 183 (4th ed. 1987); Cohen, supra note 62, at 1191 (arguing for different rules); Lemley, supra note 52, at 1599 (arguing that the two doctrines should be coextensive, but noting that currently they are not); Robert P. Merges, Reflections on Current Legislation Affecting Patent Misuse, 70 J. Pat. \& Trademark OfF. Soc'y 793 (1988) (arguing for different rules).

Whether or not Peggy Radin is correct that one should never be held to things that one has written more than two years before, see MARGaret JANE RADIN, REINTERPRETING Property 1 (1993), I must here confess error in this debate. I now believe that there may be circumstances in which rules peculiar to patent law make it appropriate to apply the misuse doctrine but do not warrant invocation of antitrust law. So too with copyright law. The application of the patent (or copyright) misuse doctrines, however, should be coupled with a reasonable mechanisun to link the harm charged with the remedy administered; on that point (the thesis of my earlier paper), I an resolute. See Lemley, supra note 52 , at 1614-20.

189. Notable on this list is extension of a patent license beyond the term of the patent. See Brulotte v. Thys Co., 379 U.S. 29, 38 n.3 (1964) (dissenting opinion). Other possible examples include non-metered royalties, grantback clauses, and resale field-of-use restrictions. See Richard Calkins, Patent Law: The Impact of the 1988 Patent Misuse Reform Act and Noerr-Pennington Doctrine on 
By contrast, copyright misuse has departed rather markedly from antitrust principles. While Goldstein refers to the "antitrust misuse defense" in copyright, ${ }^{190}$ and a number of early cases tested copyright misuse with explicit reference to antitrust principles, ${ }^{191}$ most of the cases that have found copyright misuse have done so by einploying copyright policy, not antitrust policy, as their rationale. ${ }^{192}$ The basis for copyright misuse seems to be that courts should not assist the expansion of a copyright beyond its statutory bounds, as they would do were they to enforce an improperly-broadened copyright. ${ }^{193}$ This policy is particularly strong when the agreement between the parties has significant external effects; ${ }^{194}$ indeed, virtually all of the cases finding copyright misuse have that characteristic. There are a number of cases involving

Misuse Defenses and Antitrust Counterclaims, 38 DRAKE L. REv. 175, 187 n.38 (1989) (cataloguing types of patent misuse defenses). In addition, even where patent misuse covers the same conduct as antitrust law, it may be easier to prove because it does not always require proof of market power or anticompetitive effect. See Lemley, supra note 52, at 1611-13.

190. 2 Goldstein, supra note 134, at 9:38-1 to 9:39 and cases cited therein.

191. See BellSouth Advertising \& Publ'g Corp. v. Donnelley Information Publ'g, Inc., 933 F.2d 952, 961 (11 th Cir. 1991) (refusing to find copyright misuse "in the context before us because there is no antitrust violation"), vacated, 977 F.2d 1435 (1992); CBS v. American Soc'y of Composers, Authors \& Publishers, 562 F.2d 130, 141 n.29 (2d Cir. 1977) (finding misuse on grounds coextensive with antitrust violation), rev'd, 441 U.S. 1 (1978); 4 NiMMER ON COPYRIGHT, supra note 127, at 13-284 (referring to "misuse through violation of the antitrust laws," but also noting broader readings of copyright misuse).

192. See Practice Management Info. Corp. v. American Med. Ass'n, 121 F.3d 516, 521 (9th Cir. 1997), amended by 133 F.3d 1140 (1998) (suggesting that copyright misuse need not constitute an antitrust violation); Lasercomb Am., Inc. v. Reynolds, 911 F.2d 970, 978 (4th Cir. 1990) (describing misuse as "an equitable defense to an infringement action" that applies where "the copyright is being used in a manner violative of the public policy einbodied in the grant of a copyright"); $c f$. Bateman $v$. Mnemonics, Inc., 79 F.3d 1532, 1547 (11th Cir. 1996) (suggesting that copyright misuse might be appropriate to prevent a copyright owner from capturing protection for an idea in violation of 17 U.S.C. § 102(b)). But see Reed-Umion Corp. v. Turtle Wax, Inc., 77 F.3d 909 (7th Cir. 1996) (suggesting that copyright misuse is limited to cases in which the antitrust laws are violated).

This is not to say that a fmding of copyright misuse could never be grounded in antitrust doctrine. As McGowan notes, certain copyright licensing practices in the software context may raise antitrust concerns because they either lock in control over a strong network market, see Mark A. Lemley \& David McGowan, Legal Implications of Network Economic Effects, 86 CALIF. L REv. 479, 523-41 (1998); McGowan, supra note 145, at 69, or allow a copyright owner to extend its control into neighboring markets, see David McGowan, Regulating Competition in the Information Age: Computer Software as an Essential Facility Under the Sherman Act, 18 HASTINGS COMM. \& ENT. LJ. 771 (1996) [heremafter McGowan, Regulating Competition].

Finally, it should be noted that while this Section focuses on the rationales courts have used to find misuse, many-indeed most-cases considering a copyright misuse claim have not found misuse. I hope my presentation of the former set of cases will not mislead anyone into thinking that defendants arguing misuse always-or even often-prevail.

193. See M. Witunark \& Sons v. Jensen, 80 F. Supp. 843, 849 (D. Minn. 1948).

194. See Merges, supra note 1 , at $1606 \mathrm{n} .96$ ("Under... [misuse] doctrines, courts refuse to enforce voluntary, bilateral contracts that presumably benefit both parties .... The only workable rationale for such a prohibition inust be that the contracts, though mutually beneficial to the contracting parties, harm third parties."). 

licensing that find or imply misuse; ${ }^{195}$ I discuss two of these cases in
more detail below.

195. See Lasercomb America, Inc. v. Reynolds, 911 F.2d 970 (4th Cir. 1990), and DSC Communications Corp. v. DGI Technologies, 81 F.3d 597 (5th Cir. 1996), which are discussed below. See also Practice Management Info. Corp. v. American Med. Ass'n, 121 F.3d 516, 520-21 (9th Cir. 1997), amended by 133 F.3d 1140 (1998) (finding that AMA license of its works to government agency on the condition that they did not use a competing work was copyright misuse, even though the clause was not enforced); PRC Realty Sys., Inc. v. National Ass'n of Realtors, No. 91-1125, 1992 U.S. App. LEXIS 18017 , at $* 36$ (4th Cir. Aug. 4, 1992) (invalidating a license agreement for copyright misuse because it precluded competition by licensees); F.E.L. Publications, Ltd. v. Catholic Bishop, 214 U.S.P.Q. 409, $413 \mathrm{n} .9$ (7th Cir. 1982) (noting in dictum that "it is copyright misuse to exact a fee for the use of a musical work which is already in the public domain"); Tamburo v. Calvin, No. 94 C 5206, 1995 U.S. Dist. LEXIS 3399, *16-18 (N.D. Ill. Mar. 17, 1995) (holding that a software license agreement that prevents the development of competing products, whether or not based in software, constituted patent misuse); qad, inc. v. ALN Assocs., 770 F. Supp. 1261, 1267-69 (N.D. 111. 1991) (holding that wrongly asserting copyright infringement on the basis of material that in faet plaintiff copied from another was copyright misuse, and precluding plaintiff from asserting even the original portions of the copyrighted work), aff d, 974 F.2d 834 (7th Cir. 1992); Broadcast Music, Inc. v. Moor-Law, Inc., 527 F. Supp. 758, 772 n.24 (D. Del. 1981) ("Copyright misuse and antitrust analysis in this area are not necessarily coextensive."); Vogue Ring Creations, Inc. v. Hardman, 410 F. Supp. 609, 615-16 (D.R.I. 1976) (finding that material misstatements in copyright registration form constituted copyright misuse); $c f$. Coleman v. ESPN, Inc., 764 F. Supp. 290, 295 (S.D.N.Y. 1991) (holding that defendant could proceed to trial on its copyright misuse defense).

Commentators are also divided on whether copyright misuse is broader than antitrust law, but lean heavily towards the view that it is. See Sean Michael Aylward, The Fourth Circuit's Extension of the Misuse Doctrine to the Area of Copyright: A Misuse of the Misuse Doctrine?, 17 U. DAYTON L. REV. 661, 692 (1992) (stating that copyright misuse doctrine is broader than antitrust law, but shouldn't be); Cohen, supra note 62 (arguing for application of misuse outside the antitrust context); Timothy H. Fine, Misuse and Antitrust Defenses to Copyright Infringement Actions, 17 Hastings LJ. 315 (1965) (arguing that misuse can occur without an antitrust violation); Marshall Leaffer, Engineering Competitive Policy and Copyright Misuse, 19 U. DAYToN L. REv. 1087, 1099-1100 (1994) ("Most courts have declared that the misuse defense does not require proof of an antitrust violation."); John G. Mills, Possible Defenses to Complaints for Copyright Infringement and Reverse Engineering of Computer Software: Implications for Antitrust and I.P. Law, 80 J. PAT. \& TRADEMARK OFF. Soc'y 101, 119 (1998) (arguing that copyright misuse does not require a showing of injury to competition); O'Rourke, supra note 62 , at 550 (stating "it seems that the quantum of proof is somewhat less" in a copyright misuse than in an antitrust case); Troy Paredes, Copyright Misuse and Tying: Will Courts Stop Misusing Misuse?, 9 HigH TЕсH. LJ. 271, 330 (1994) (arguing that copyright misuse should be abolished, and only antitrust violations should be considered); David Schcr, The Viability of the Copyright Misuse Defense, 20 FordHam URB. L.J. 89, 102 (1992) (arguing that misuse should cover all extensions of copyright); Richard Stitt, Copyright Self-Help Protection as Copyright Misuse: Finally the Other Shoe Drops, 57 UMKCL. REv. 899 (1989) (arguing that misuse is distinct from antitrust); Toshiko Takenaka, Extending the New Patent Misuse Limitation to Copyright: Lasercomb America, Inc. v. Reynolds, 5 SOFTwARE L.J. 739, 746-48 (1992) (arguing for an antitrust-based approach to misuse); White, supra note 63, at 273, 287-88 (arguing that "misuse is independent of antitrust" and should be, at least for software); Philip Abromats, Comment, Copyright Misuse and Anticompetitive Software Licensing Restrictions: Lasercomb America, Inc. v. Reynolds, 52 U. PITT. L REv. 629 (1991) (arguing for antitrust-based treatınent of misuse); Ramsey Hanna, Note, Misusing Antitrust: The Search for Functional Copyright Misuse Standards, 46 STAN. L. REv. 401 (1994) (arguing that misuse should be independent of, but marrower than, antitrust); Note, Clarifying the Copyright Misuse Defense: The Role of Antitrust Standards and First Amendment Values, 104 HARv. L REv. 1289 (1991) (arguing that copyright misuse should properly have both antitrust and pro-dissemination objectives).

For an interesting argument that network effects in the software industry support reliance on misuse principles independent of antitrust, see White, supra note 63, at 277-80; cf. Mark A. Lemley \& 
In Lasercomb America, Inc. v. Reynolds, ${ }^{196}$ the plaintiff brought a copyright claim to enjoin Reynolds from copying its computer-assisted die-making software. The district court found for plaintiff and enjoined the infringement. On appeal, the Fourth Circuit found that plaintiff was not entitled to relief because it had misused its copyright by insisting upon and enforcing a standard form licensing agreement that attempted to expand its rights beyond those granted by copyright law. ${ }^{197}$ In particular, the court noted that the licensing agreement contained clauses precluding any licensee or employee from developing any competing software for a period of 99 years. ${ }^{198}$ Thus, it refused to permit the plaintiff to invoke the equity power of the courts to enforce the copyright, and reversed both the grant of injunctive relief and the award of damages. Notably, the court held that plaintiff's anticompetitive licensing provisions barred enforcement of the copyright despite the fact that defendants were not parties to the standard licensing agreement. ${ }^{199}$ Also of note is that while the contract clauses at issue in Lasercomb probably had anticompetitive effects, there was no need for the court to find that the clauses themselves violated the antitrust laws.

More recently, in DSC Communications v. DGI Technologies, ${ }^{200}$ the Fifth Circuit expressly tied the copyright misuse doctrine to the plaintiff's attempt to expand the copyright beyond its scope and "obtain a patent-like inonopoly."201 In that case, DSC sold a microprocessor card for use on its phone switches, which ran on DSC's copyrighted operating system. DGI wanted to sell a competing 1microprocessor card compatible with DSC's switch. In order to build a compatible card, DGI tested its card on a DSC phone switch, which necessitated making a temporary copy of the operating system in the

David McGowan, Could Java Change Everything? The Competitive Propriety of a Proprietary Standard, 43 ANTITRUST BuLL. (forthcoming Fall 1998) (discussing the problems in applying both antitrust and intellectual property law in network industries); Lemley \& McGowan, supra note 192, at 500-41 (same).

196. 911 F.2d 970 (4th Cir. 1990).

197. See id. at 978 .

198. See id. at 978 .

199. See id. at 979 . This reinedial approach is analogous to the one $I$ have criticized in the patent misuse cases. See Lemley, supra note 52, at 1614-20. Fortunately, other courts and cominentators have suggested that the copyright misuse doctrine may be more narrowly tailored than the patent misuse doctrine. See Midway Mfg. Co. v. Artic Int'l, Inc, 211 U.S.P.Q. 1152, 1161 (N.D. Ill. 1981) (stating that a copyright misuse defense is allowed only when "the plaintiff's transgression ... relates directly to the subject matter of the infringement action"); 2 GoLDSTEIN, supra note 134, at 9:39 (suggesting that to prevail, the defendant must show that "the alleged anticoinpetitive conduct relates directly to the claim of copyright infringement"). One patent misuse case has also imposed a similar requireinent. See Kolene Corp. v. Motor City Metal Treating, Inc., 440 F.2d 77, 85 (6th Cir. 1971) ("TT]he misconduct must be connected with the matter in litigation ....").

200. 81 F.3d 597 (5th Cir. 1996).

201. Id. at 601 . 
switch. ${ }^{202}$ The court rejected DSC's copyright infringement claim based on such temporary copying, finding that DSC's assertion of the claim was likely to constitute copyright misuse because it effectively asserted copyright control, not merely over the operating system software, but also over the unprotected microprocessor card. ${ }^{203}$ For a court to find likely copyright misuse here, it necessarily had to conclude that DSC's copyright argument would prove unpersuasive, an issue on which other courts have disagreed. ${ }^{204}$ The decision also suggests, however, that a copyright owner may commit misuse by improperly attempting to extend the power of the copyright beyond the scope granted by the law. As im Lasercomb, there is no antitrust analysis in the DSC opinion, suggesting that the court did not consider proof of an antitrust violation necessary for a finding of misuse.

By contrast, copyright owners seeking to expand the monopoly on their computer operating systems to cover hardware and software maintenance ${ }^{205}$ have for the most part withstood attack under both antitrust and copyright misuse principles. ${ }^{206}$ But it is worth noting that, in these cases, the determinative issue seems to have been whether copyright law extends to cover computer maintenance because it requires turning on the computer (and therefore loading the copyrighted software into RAM). For courts that believe this RAM copying is within the scope of the exclusive right to copy, the misuse issue should not arise because the copyright owner is not seeking to expand the scope of the copyright beyond its legal bounds. ${ }^{207}$ On the other hand, those who find this

202. See id. at 599.

203. See id. at 601 .

204. See MAI Sys. Corp. v. Peak Computing, Inc., 991 F.2d 511, 518 (9th Cir. 1993) (holding that the making of temporary copies of the operating system in a chip is copyright infringement). For a discussion of the debate over the meaning of fixation in the digital context, see Lemley, Overlapping Copyrights, supra note 15, at 550-52 (discussing cases and legislative history on both sides of the issue); Litman, Exclusive Right, supra note 63, at 40.

205. The paradigm case is MAI Systems Corp., 991 F.2d at 518, which found copyright infringement based on such a claim.

206. See In re Independent Serv. Orgs. Antitrust Litig., 910 F. Supp. 1537, $1541-42$ (D. Kan. 1995); Advanced Computer Servs., Inc. v. MAI Sys. Corp., 845 F. Supp. 356, 362 (E.D. Va. 1994). But see Tricom, Inc. v. Electronic Data Sys. Corp., 902 F. Supp. 741, 746 (E.D. Mich. 1995) (holding that tying hardware and software maintenance could lead to antitrust liability).

207. The holdmg in In re Independent Service Organizations, for example, is dependent on this conclusion. See 910 F. Supp. at 1543 (considering antitrust liability based on the assumption that RAM copying was copyright mfringement). Indeed, the same court later concluded that whether there was copyright misuse in the case before it depended on a question of material fact: "the scope of Xerox's copyrights." In re Independent Serv. Orgs. Antitrust Litig., 964 F. Supp. 1469, 1477 (D. Kan. 1997). 
construction of the copyright laws implausible ${ }^{208}$ should be inclined to find misuse in this context. ${ }^{209}$

Copyright owners who seek to obtain by contract what copyright law will not give them will have to face these cases. Like preemption, copyright misuse won't cover the full range of potentially troubling licensing practices. For one thing, copyright misuse is a defense limited to copyright cases, and therefore of uncertain applicability in cases in which copyright law denies all protection for a work. ${ }^{210}$ It also may be of no help in cases in which only state law rights are at issue. ${ }^{211}$ For example, a plaintiff who truly does "opt out" of copyright in favor of contract presumably would not be bound by the limits of the copyright misuse defense. And it might not bar a contract claim even if it barred a copyright claim in the saine case. Furthermore, the misuse doctrine is a defense to an infringement claim, and it therefore won't help copyright owners who complain about improper licensing agreements forced upon them by licensees.

Nonetheless, copyright misuse doctrine readily disposes of the "contracts are different" canard, because it so clearly operates (as in Lasercomb) to restrict the enforcement of anticompetitive licensing provisions. It also may be more apt than fair use doctrine in preventing some anticompetitive extension of copyright. ${ }^{212}$ In any event, copyright misuse can't be waived by contract. Furthermore, because copyright misuse is a fact-specific doctrine tailored to the circumstances of individual cases, it may prove a better tool both for tailoring copyright

208. This group includes virtually all commentators who have considered the issue. See supra note 63 (collecting commentators).

209. See, e.g., DSC, 81 F.3d at 601; Tricom, 902 F. Supp. at 745 (stating that a copyright owner cannot "enforce its copyright to violate the antitrust laws or indeed use it in any "manner violative of the public policy einbodied in the grant of a copyright") (quoting Laserconb America, Inc. v. Reynolds, 911 F.2d 970, 978 (4th Cir. 1990)). The Tricom court found that the plaintiff's MAI-based RAM copying claim did not preclude antitrust hability. See Tricom, 902 F. Supp. at 745; see also 4 NIMMER ON COPYRIGHT, supra note 127, at 13-290 to 291 (arguing that the Independent Service Organizations cases "overly constrict" the misuse defense); cf. Independent Service Organizations, 964 F. Supp. at 1477 (appearing to condition misuse determination on copyright determination).

210. In a case such as ProCD v. Zeidenberg, 86 F.3d 1447 (7th Cir. 1996), though, the doctrine might still be applicable because the plaintiff asserted a claim for copyright infringement despite the clear contrary authority of Feist Publications, Inc. v. Rural Tel. Serv. Co., Inc., 499 U.S. 340 (1991). See ProCD, Inc. v. Zeidenberg, 908 F. Supp. 640, 649 (W.D. Wis. 1996), rev'd, 86 F.3d 1447 (7th Cir. 1996).

211. One might argue that copyright misuse should apply to cases in which only state law claims are asserted, but the assertion of those claims (say, the enforcement of the contract at issue in Lasercomb) depends indirectly on the misuse of copyright. To date, there have been no cases of which $I$ an aware that address such an argument at all.

212. See Cohen, supra note 62, at 1193; White, supra note 63, at 290-91, 293-95. 
incentives and for avoiding the reticence that surrounds coarser tools such as preemption. ${ }^{213}$

\section{B. Licensing Contracts as Creatures of Federal Law}

There is no general federal common law of intellectual property licenses, ${ }^{214}$ as there is in a few other areas of federal law. ${ }^{215}$ Rather, federal law generally relies on state contract doctrine to support the myriad contracts that revolve around federal intellectual property rights. ${ }^{216}$ But in some circumstances, federal law overrides state contract doctrine, not in the sense of preempting particular contract terms, but by declaring that certain contracts will be interpreted under federal rather than state law. The occasional willingness of federal law to assume responsibility for interpreting intellectual property licenses places a second nonpreeinption limit on the ability of Article $2 \mathrm{~B}$ to change the rules of contract law in this field. ${ }^{217}$

213. See McGowan, Regulating Competition, supra note 192 (favoring copyright misuse over antitrust for this reason); $O$ 'Rourke, supra note 62, at 550 ("The copyright misuse doctrine may prove helpful to avoid transforming breach of contract litigation ... into full blown antitrust litigation.").

Further, if McGowan is correct that copyright law takes a different approach to enhancing social welfare than either antitrust or contract, see McGowan, supra note 145; McGowan, Regulating Competition, supra note 192, at 773-78, applying the principles of copyright stands the best chance of correctly resolving a conflict between copyright and contract.

214. See Everex Co. v. Cadtrak Corp., 89 F.3d 673, 678 (9th Cir. 1996) ("The construction of a patent license is generally a matter of state contract law ....”); McCoy v. Mitsuboshi Cutlery, Inc., 67 F.3d 917, 920 (Fed. Cir. 1995) ("[A] license is a contract governed by ordinary principles of state contract law."); Bartsch v. Metro-Goldwyn-Mayer, Inc., 391 F.2d 150, 153 (2d Cir. 1968) (finding that there is no general federal common law of copyright). But see In re Alltech Plastics, Inc., 71 B.R. 686,689 (W.D. Tenn. 1987) ("The rights of the patent owner to license the use of his invention is a creature of federal common law ....”); Great Lakes Press Corp. v. Froom, 695 F. Supp. 1440, 1445 (W.D.N.Y. 1987) (referring to the "body of federal common law" that has developed in patent cases).

215. See Textile Workers Union v. Lincoln Mills, 353 U.S. 448, 451 (1957) (holding that fedcral common law governs collective bargaining disputes); D'Oench, Duhme \& Co., Inc. v. FDIC, 315 U.S. 447, 455 (1942) (holding that federal common law govcrns FDIC-insured banking). See generally Paul M. Bator et al., Hart \& Wechsler's The Federal Courts and the Federal System 744-847 (4th ed. 1996) (discussing federal common law).

216. See, e.g., Dow Chemical Co. v. Exxon Corp., 139 F.3d 1470, 1474 (Fed. Cir. 1998) (noting the "traditional domain" of state law in interpreting patent contracts); Nimmer ct al., supra note 8, at 26-27.

217. One should distinguish the apphication of federal law and policy from litigation in federal court. See Jim Arnold Corp. v. Hydrotech Sys., Ine., 109 F.3d 1567, 1571 (Fed. Cir. 1996) (concluding that a claim based on breach of patent license is a state law claim over which the federal courts had no jurisdiction). Federal law may apply even though the dispute is litigated in state court. Indeed, in cases such as Consolidated Kinetics Corp. v. Marshall, Neil \& Pauley, Inc., 521 P.2d 1209, 1212-13 (Wash. Ct. App. 1974), and Lear Sieglar, Inc. v. Sargent Industries, Inc., 374 A.2d 273, $276-77$ (Del. Super. Ct. 1977), in which the state court actually determines the validity of the patent in the course of deciding a licensing dispute, there seems to be no question that federal law and policy must apply. See generally Donald Shelby Chisum, The Allocation of Jurisdiction Between State and Federal Courts in Patent Litigation, 46 WASH. L. REv. 633 (1971) (discussing federal patent cases litigated in state court). And one case even dismissed federal jurisdiction over a copyright infringement complaint 
A variety of federal intellectual property doctrines trump state law. In some cases, notably assignments of copyrights and patents, the federal statute itself governs the way in which transfers can be lawfully made. ${ }^{218}$ Even where the federal statute is silent, determinations of whether an intellectual property right may be transferred in a particular circumstance tend to be decided as questions of federal law. ${ }^{219}$ The same is true of the rules for how the transfer must be recorded, ${ }^{220}$ and perhaps

because it concluded that the copyright suit was "incidental" to a contract dispute over ownership of the copyright, and that the dispute belonged in state court. See Robinson v. Princeton Review Inc., 41 U.S.P.Q.2d 1008, 1012 (S.D.N.Y. 1996). This fact, in itself, has disturbed some commentators who worry that sensitive issues of federal law are being decided by state courts which may not fully understand them. See Mark J. Henry, State Courts Hearing Patent Cases: A Cry for Help to the Federal Circuit, 101 Dick. L. REv. 41 (1996) (arguing that state courts are incapable of understanding complex issues of patent policy and that all patent license and assignment disputes should be decided by federal courts).

218. See, e.g., 17 U.S.C. § 204 (1994); 35 U.S.C. \& 261 (1994); Jacob Maxwell Inc. v. Veeck, 110 F.3d 749, 752 (11th Cir. 1997) (holding that an oral agreement to grant exclusive copyright license was invalid under federal law, but that a nonexclusive license could be implied under federal law notwithstanding contrary state rules of contract interpretation); $c f$. Enzo APA \& Son, Inc. v. Geapag A.G., 134 F.3d 1090, 1093 (Fed. Cir. 1998) (holding that patent plaintiff lacked standing to file suit as patentee because purported exclusive license was not in writing, as federal case law requires).

This is not to say that courts necessarily agree on how section 204 is to be interpreted. Compare Konigsberg Int'l Inc. v. Rice, 16 F.3d 355, 357 (9th Cir. 1994) (holding that section 204 requires a negotiated agreement to prevent madvertent loss of copyright rights), with Zyware, Inc. v. Middlegate, Inc., No. 96 CIV. 2348 (SHS), 1997 WL 685336, at *3 (S.D.N.Y. Nov. 4, 1997) (holding that any written "agreement" suffices).

219. See, e.g., Everex Co. v. Cadtrak Corp., 89 F.3d 673, 679 (9th Cir. 1996) (holding that assignability of nonexclusive patent license was a question of federal, not state, law); S.O.S., Inc. v. Payday, Inc., 886 F.2d 1081, 1088 (9th Cir. 1989) ("The license must be construed in accordance with the purposes underlying federal copyright law. [State contract law can be enforced] only to the extent such rules do not interfere with federal copyright law or policy."); Harris v. Enus Records Corp., 734 F.2d 1329, 1333 (9th Cir. 1985) (holding that federal law governs transferability of nonexclusive copyright licenses); PPG Indus., Inc. v. Guardian Indus. Corp., 597 F.2d 1090, 1093 (6th Cir. 1979) (holding that assignability of nonuxclusive patent license was a question of federal rather than state law); Unarco Indus., Inc. v. Kelley Co., 465 F.2d 1303, 1306 (7th Cir. 1972) (same); Tasini v. New York Times Co., 972 F. Supp. 804, 807 (S.D.N.Y. 1997) (holding that attempt by publishers to license electronic reprint rights from authors by including a legend on the royalty check was ineffective under federal law); In re Patient Education Media, Inc., 210 B.R. 237, 240 (Bankr. S.D.N.Y. 1997) (holding that debtor cannot assign nonexclusive license without consent of copyright owner). But cf. Yount v. Acuff Rose-Opryland, 103 F.3d 830, 835 (9th Cir. 1996) (holding that a contract assigning royalty interests in copyright, but not the copyright itself, is construed under state law); Farmland Irrigation Co., Inc. v. Dopplmaier, 308 P.2d 732, 737-39 (Cal. 1957) (stating that no federal patent policy "requires a uniform federal rule of construction of license contracts to determine their assignability").

Jessica Litman points out that a rule of nontransferability of nonexclusive licenses makes little sense in the copyright context. See Litman, supra note 4, at 2 n.4. Nonetheless, the case law does exist, and it is unquestionably federal case law.

220. See 17 U.S.C. $\$ 205$ (1994) (providing for a certain set of priority rules betwcen conflicting claimants to copyright ownership). As Paul Heald notes, however, section 205 does not exhaust the issues that conie up when intellectual property is used as collateral, and therefore does not necessarily preempt all state regulation in the area. See Heald, supra note 142, at 140. 
even the basic rules of contract law under which the transfer will be interpreted. 221

Similarly, a variety of patent and copyright ownership rules are determined by federal law rather than state contract law, even in circumstances in which that determination requires the court to interpret an assignment agreement. ${ }^{222}$ Whether a copyrighted work is initially owned by the individual creator or another depends on whether it is a work made for hire; that determination is made on the basis of federal law. ${ }^{223}$ Federal estoppel doctrines (or their opposites) may supersede state contract law interpretation, such as when assignors are precluded from

Even so, courts have applied federal law to many of these interstices. For example, a number of courts have held that security interests in copyrights must be registered with the Copyright Office, not with state offices (as Article 9 of the U.C.C. would otherwise provide). See U.C.C. 9-101 (1997); In re AEG Acquisition Corp., 127 B.R. 34, 40 (Bankr. C.D. Cal. 1991), aff'd, 161 B.R. 50 (9th Cir. B.A.P. 1993); In re Peregrine Entertainunent Ltd., 116 B.R. 194, 199 (C.D. Cal. 1990); see also Shubha Ghosh, The Morphing of Property Rules and Liability Rules: An Intellectual Property Optimist Examines Article 9 and Bankruptcy, 8 Fordham Intel.L. Prop. Media \& ENT. L.J. 99 (1997); Shawn K. Baldwin, Comment, "To Promote the Progress of Science and Useful Arts": A Role for Federal Regulation of Intellectual Property as Collateral, 143 U. PA. L. REv. 1701, 1731 (1995) (endorsing the federal approaeh). For criticism of this approach, see Haemmerli, supra note 14, at 1680-95; Aimee A. Watterberg, Comment, Perfecting a Security Interest in Computer Software Copyrights: Getting It Right, 15 J. MARSHALl J. COMPUTER \& INFO. L. 855, 867 (1997) (endorsing a federal approach, but arguing that the current system needs significant clarification). Haemmerli also notes the potentially contrary rule in patent cases. See Haemmerli, supra note 14 at 1697-98. For further discussion of the intellectual property recording rules, see Ronald J. Mann, The Role of the U.C.C. im Facilitating the Financing of Software Licenses 12 (1998) (unpublished manuscript, on file with author).

221. The Nimmer treatise suggests that a transfer of copyright ownership does not require consideration, despite the fact that consideration is ubiquitous in state contract doctrine. See 3 NMMER ON COPYRIGHT, supra note 127, at § 10.03[A][8].

222. See, e.g., 35 U.S.C. § 118 (1952) (allowing for "involuntary assignment," permitting rightful patent owner to file for a patent without the permission of the actual inventor, if the inventor had an obligation to assigu the invention); Stark v. Advanced Magnetics Inc., 119 F.3d 1551, 1554 (Fed. Cir. 1997) (holding that determination of inventorship under 35 U.S.C. $\S 256$ is a matter of federal patent law). Note that it does not follow that state law is entirely preeinpted in these circumstances; a fraud claim may still lie, for example, against someone who steals an invention and patents it in his name. See University of Colo. Found., Inc. v. Am. Cyanamid Co., 974 F. Supp. 1339, 1353 (D. Colo. 1997). But the determination of ownership of the patent itself is a matter of patent law, not contract law.

An instructive case is Schering Corp. v. Roussel-UCLAF SA, 104 F.3d 341 (Fed. Cir. 1997). There, the Federal Circuit held that where two parties co-owned a patent, either one was free to license the work to third parties. See id. at 344 . However, the licensor could not prevent his co-owner from suing the licensee for past acts of patent infringement because the licensor did not have the power to grant a release of past liability to the co-owner. See id. at 345 . This is a rule of federal law interpreting the meaning of a license agreement, not a result of the terms of the agreement itself.

223. See 17 U.S.C. \$ 101 (1994) (defining "work made for hire"). Ginsburg notes that Article 2B will not cover most agreenents designating works as made for hire, because they are not licenses but are rather outright assignments of all intellectual property interests. See Ginsburg, supra note 4. Article $2 \mathrm{~B}$ will still apply, however, to the extent that the agreement on assignment or work for hire status constitutes a "software contract" or an "access contract." See U.C.C. § 2B-103(a)(1) (Draft, Aug. 1, 1998). 
challenging patent validity, ${ }^{224}$ or licensors are permitted to do so. ${ }^{225}$ In addition, if the interpretation of a contract requires a determination of the existence or scope of a federal right, such as a patent, that determination will be made as a matter of federal rather than state law. ${ }^{226}$

An instructive case is S.O.S., Inc. v. Payday, Inc., ${ }^{227}$ in which the court noted that state contract law could not be applied where it interfered with copyright law or copyright policy. ${ }^{228}$ The district court had applied a California rule of contract construction which requires that courts interpret contracts against the drafter. The Ninth Circuit held that the California rule could not be applied to copyright license agreements because it was "contrary to [the] federal copyright policy" that licenses do not impliedly grant rights not expressly authorized. ${ }^{229}$ While one can agree or disagree with the substantive result in this case-I for one don't find it terribly persuasive ${ }^{230}$-it is worth noting that even core canons of contract interpretation are not immune froin the dictates of federal policy. ${ }^{231}$

Other cases do not involve federal law interpretation of a contract per se, but impose federal restrictions on contract terms in order to protect inportant aspects of federal policy. ${ }^{232}$ One might think of these cases as analogous to ones in which state courts invalidate contracts on grounds of public policy, but here the public policy at issue derives

224. See, e.g., Carroll Touch, Inc. v. Electro Mechanical Sys., Inc., 3 F.3d 404 (Fed. Cir. 1993) (holding that an inventor is estopped from challenging the validity of his own patent-later assigned to another-when the patent application was based on his representations to the Patent and Trademark Office); Diamond Scientific Co. v. Ambico, Inc., 848 F.2d 1220, 1224 (Fed. Cir. 1988) (finding that assignor estoppel prevents inventor from challenging patent validity).

225. See Lear, Inc. v, Adkins, 395 U.S. 653, 664 (1969); see also Saturday Evening Post Co. v. Ruinbleseat Press, Inc., 816 F.2d 1191, 1200 (7th Cir. 1987) (rejecting licensee estoppel in copyright law, even where the licensee had expressly agreed not to challenge the copyright). But see Studiengesellschaft Kohle, M.B.H. v. Shell Oil Co., 112 F.3d 1561, 1565 (Fed. Cir. 1997) (rejecting Lear and concluding that contract law may sometimes defeat patent policy in this area), cert. denied, 118 S. Ct. 560 (1997).

226. See Dow Chemical Co. v. Exxon Corp., 139 F.3d 1470, 1475 n.4 (Fed. Cỉr. 1998).

227. 886 F.2d 1081 (9th Cir. 1989).

228. See id. at 1088 .

229. Id.

230. The conclusion that the terms of a form license agreement must always be construed to grant only what the license itself states seems at odds with a number of other decisions, including a subsequent decision by the Ninth Circuit that granted an implied license to use a copyrighted work. See Effects Assoc., Inc. v. Cohen, 908 F.2d 555, 558 (9th Cir. 1990); see also Jacob Maxwell Inc. v. Veeck, 110 F.3d 749, 751 (11th Cir. 1997); I.A.E., Inc. v. Shaver, 74 F.3d 768, 774 (7th Cir. 1996).

231. See Fantastic Fakes, Inc. v. Pickwick Int'l, Inc., 661 F.2d 479, 483 (5th Cir. 1981) (noting that "[i]t is possible to liypothesize situations where application of particular state rules of construction would so alter rights granted by the copyright statutes as to invade the scope of copyright law or violate its policies," but concluding this was not such a case).

232. See SQL Solutions, Inc. v. Oracle Corp., No. C-91-1079 MHP, 1991 U.S. Dist. LEXIS 21097, at $* 7$ (N.D. Cal. Dec. 18, 1991) ("F] $]$ ederalism principles dictate that state rules of contractual construction cannot interfere with federal law or policy."). 
from federal rather than state law. ${ }^{233}$ In a number of trademark cases, for example, federal policy restricts the enforceability of a franchise trademark licensing agreement because unrestricted licensing of a trademark is inconsistent with the goals of trademark law. ${ }^{234}$ Another example is Fasa Corp. v. Playmates Toys, Inc., ${ }^{235}$ where the court held that the parties to a settlement agreement could not waive all future intellectual property claims that might later arise. ${ }^{236}$ One can readily imagine other circumstances in which federal policy might step in to preclude contract enforcement. For example, it is well-established that once an invention is patented, trade secret protection for that invention is lost. ${ }^{237}$ If a patentee tried to require that a licensee continue to treat the patented invention as a trade secret, that agreement might well be invalid on federal public policy grounds. ${ }^{238}$

In short, parties that would enforce contract terms cannot look only to state law in the wake of Article 2B. In some cases, such as those dealing with ownership and transfers, state law simply may not be the source

233. Many of the cases discussed above that apply federal law to an entire area of licensing do so because of important federal policies, and so might be thought to fit in this category as well. For a good example, see Everex Systems, Inc. v. Cadtrak Corp., 89 F.3d 673, 679 (9th Cir. 1996), in which the court discusses the imiportant federal policies that support allowing the patentee to govern assignability of nonexclusive licenses. But see Dreyfuss, supra note 4, at 227-29 (suggesting that Everex may be wrong about federal policy in this area); Daniel A. Wilson, Note, Patent License Assignment: Preemption, Gap Filling, and Default Rules, 77 B.U. L. REv. 895 (1997) (same).

Another possible area of federal policy interest is in rights of indemnification and contribution against intellectual property infringement claims. For an excellent discussion of the labrynthine federal and state rules in this area, see David Hricik, Remedies of the Infringer: The Use by the Infringer of Implied and Common Law Federal Rights, State Law Claims, and Contract to Shift Liability for Infringement of Patents, Copyrights, and Trademarks, 28 TEx. TECH L. REv. 1027 (1997).

234. See 15 U.S.C. $\$ 1060$ (1994) (providing that a trademark may be assigned along with the goodwill of a business); American Steel Foundries v. Robertson, 269 U.S. 372, 380 (1926) (assignment in gross); Stanfield v. Osborne Indus., Inc., 52 F.3d 867, 871 (10th Cir. 1995) (holding trademark rights lost due to unsupervised license); Mariniello v. Shell Oil Co., 511 F.2d 853, 858 (3d Cir. 1975) (precluding trademark registration due to naked liccnsing); Pepsico, Inc. v. Grapette Co., Inc., 416 F.2d 285, 288 (8th Cir. 1969) (holding assignment in gross invalid); Dawn Donut Co., Inc. v. Hart's Food Stores, Inc., 267 F.2d 358 (2d Cir. 1959); 2 McCARThY on Trademarks, supra note 95, at $\$ 18.01$; MERGES ET AL., supra note 43 , at $698-99$ (discussing the assignments in gross rule).

235. 892 F. Supp. 1061 (N.D. Ill. 1995).

236. Id. at 1066. But cf. National Presto Indus. Inc. v. Dazey Corp., 107 F.3d 1576, 1580-82 (Fed. Cir. 1997) (stating that federal courts do not have continuing jurisdiction to enforce settlement agreement in a patent case).

237. See, e.g., Ferroline Corp. v. General Aniline \& Film Corp., 207 F.2d 912, 919 (7th Cir. 1953).

238. Indeed, patentees occasionally have been subject to antitrust attack for attempting to patent an invention and then claiming the same invention as a trade secret after the patent expired. See United States v. Pilkington PLC, No. 94-345 (D. Ariz. Dec. 22, 1994).

The attempt to get sucli dual protection for a single invention should be distinguished from Aronson v. Quick Point Pencil Co., 440 U.S. 257, 263-64 (1979), in which the Suprene Court held that a patent applicant could enforce a royalty agreenient that continued to claim as a secret an invention that did not qualify for patent protection. 
of the interpretive rule. ${ }^{239}$ While federal courts could conceivably adopt Article $2 \mathrm{~B}$ by analogy in such cases, it is unlikely that they will so readily cede substantive control over a choice that they have already decided to make a question of federal law. Furthermore, even if Article 2B applies in contract interpretation, the contract terms are not immune from the dictates of federal policy. As seen above, in cases in which the contract threatens a significant federal interest, courts have shown no hesitation in interposing federal law as a limit on contractual freedom. As the conflict between federal policy and contract law sharpens in the wake of Article 2B, it would seem quite reasonable to expect an expanded role for federal public policy limits on contract enforcement. For example, a court might well conclude that a "no-reverse-engineering," "nocriticism," or "no-parody" clause in a contract was unenforceable as a matter of federal policy, without invoking the mechanisms of preemption.

\section{State Public Policy Limits on Intellectual Property Contracts}

State law and public policy also place limits on the freedom of contract afforded in state contract law. These limits are of two types. First, contract law itself typically will refuse to enforce certain types of contract terms, such as those that are unconscionable. Because these public policy restraints are internal to contract law, their continued existence depends on the way the contract statute is drafted. Article 2B contains a few such restrictions, although as noted above, it contains fewer such provisions than does its Article 2 counterpart. ${ }^{240}$ Moreover, even though Article $2 \mathrm{~B}$ provides that substantively unconscionable contract terms will not be enforced, ${ }^{241}$ our experience with Article 2 cases makes it clear that courts rarely invoke the unconscionability doctrine to strike terms. ${ }^{242}$ The same will undoubtedly continue to be true in Article 2B cases. Article 2B also contams a host of procedural restraints. For example, it requires certain terms to be conspicuous, or to be separately assented to, in order to be enforceable. ${ }^{243}$ Again, however, Article $2 \mathrm{~B}$

239. In some cases, a federal court will look to analogous cases for guidance in interpreting a particular term in a federal statute. See, e.g., Community for Creative Non-Violence v. Reid, 490 U.S. 730, 731 (1989) (applying common law agency principles to determine whether plaintiff was an "employee" for purposes of the works made for hire doctrine); De Sylva v. Ballentine, 351 U.S. 570, 580 (1956) (noting that the meaning of "children" in the Copyright Act could be determined by reference to state law). The use of state or common law principles in these cases, however, does not change the essentially federal nature of the inquiry. For exainple, a state could not change the meaning of the Copyright Act by adopting a new definition of "employee" or "children."

240. See supra notes 23-32 and accompanying text.

241. See U.C.C. \$ 2B-110 (Draft, Aug. 1, 1998).

242. See supra note 181 and accompanying text (noting paucity of decisions).

243. See U.C.C. \& 2B-1I1(b) (Draft, Aug. 1, 1998) (establishing rules governing assent to particular terms); id. $\S 2 \mathrm{~B}-112(\mathrm{a})(1)$ (defining opportunity to review contract terms); id. 
includes fewer such restrictions than does existing law, and it makes its procedural protections easier to waive by changing the meaning of a "contract." 244

A second set of state law public policy restrictions on contractual freedom comes from sources external to contract law, such as state intellectual property statutes or decisions. ${ }^{245}$ The clearest example in the intellectual property context has to do with noncompetition agreements. ${ }^{246}$ Enforceability of these agreements varies from state to state, but virtually all states impose some restriction on the enforceability of noncompetition agreements as a matter of public policy, and courts have not hesitated to invalidate such agreements. ${ }^{247}$ Some states impose an overarching requirement of reasonableness, including limits on the permissible scope and duration of the agreement. ${ }^{248}$ Others refuse to enforce noncompetition agreements at all in certain circumstances, such as contracts for employınent at will. ${ }^{249}$ Most restrictive are California and a few other states, which ban noncoinpetition agreements entirely in the employment context, and subject thein to stringent conditions in other contexts. 250

The state interest in promoting these public policies can be quite strong. A California court recently took the position that a

§ 2B-406(b)(6) (providing that disclaimers of implied warranties in mass-market liccnses must be conspicuous).

244. See supra notes 19-32 and accompanying text.

245. See generally Amcrican Home Assurance Co. v. Stepliens, 130 F.3d 123, 126 (5th Cir. 1997) ("Expressions of public policy are found in a state's constitution, statutes and judicial decisions.").

246. This need not be entircly a state policy issue. Arguably the federal antitrust laws embody the common law's listoric aversion to contractual restraints on trade and employment. See HerberT HoveNKAMP, ENTERPRISE AND AMERICAN LAW I836-I937, at 268-95 (1991); McGowan, supra note 145.

247. Many cases have imvalidated covenants not to compete. See, e.g., Hi-Line Elec. Co. v. Dowco Elec. Prods., 765 F.2d 1359 (5th Cir. 1985); NCH Corp. v. Broyles, 749 F.2d 247 (5th Cir. 1985); Diodes, Inc. v. Franzen, 67 Cal. Rptr. 19 (Cal. Ct. App. 1968); Renal Trcatment Ctrs. v. Braxton, 945 S.W.2d 557 (Mo. 1997); Reed Roberts Assoc., Inc. v. Strauinan, 353 N.E.2d 590 (N.Y. 1976); Light v. Centel Cellular Co., 883 S.W.2d 642 (Tex. 1994).

248. See, e.g., Comprehensive Techs. Int'l, Inc. v. Softwarc Artisans, Inc., 3 F.3d 730, 738 (4th Cir. 1993) (applying Virginia law); Holloway v. Faw, Casson \& Co., 572 A.2d 510, 515 (Md. 1990); Strauman, 353 N.E.2d at 679 (applying New York law); cf. Renal, 945 S.W.2d at 557 (finding under Texas law that the noncompetition agreement was ancillary to sale of a business, but that the buyer lad no legitimate interest in preventing solicitation of patients).

249. See, e.g., Light v. Centel Cellular Co., 883 S.W.2d 642, 647 (Tex. 1994); cf. Central Adjustment Bureau, Inc. v. Ingram, 678 S.W.2d 28, 33 (Tenn. 1984) (finding noncoinpetition agreement enforccable where continuous long-term employment constituted consideration). But $c f$. Tatge v. Chambers \& Owen, Inc., 579 N.W.2d 217 (Wis. 1998) (holding that an employee can be fired for refusing to sign a noncompetition agreement, even if the agreement would be unenforceable).

250. See CAL. Bus. \& PRof. Code $\S 16600$ (Deering 1992); Monogram Indus., Inc. v. SAR Indus., Inc., $134 \mathrm{Cal}$. Rptr. 714, 718 (Cal. Ct. App. 1976) (holding noncompetition agrecments void as to employees and subject to reasonableness requircment when ancillary to the sale of a business). 
noncompetition agreement entered into in another state could not be enforced in California against the company that hired a departing employee, even though the noncompetition agreement was between two non-California parties and was valid in the jurisdiction in which it was signed. ${ }^{251}$ This raises the possibility that California's interest in preventing such contracts is so strong that California state courts will deny full faith and credit to the judgments of another state..$^{252}$

State public policy imterests in limiting the enforcement of contracts are not limited to the enforceability of noncompetition agreements. States have imposed similar restrictions on "trailer clauses," which require the assignment of inventions by former employees for a certain period after they leave their job. ${ }^{253} \mathrm{~A}$ number of states have statutes restricting the circumstances in which employers can compel their employees to assign inventions made during the course of employment. ${ }^{254}$ Other states have expressed public policy interests in various aspects of trade secret law, in some cases refusing to allow the parties to preclude reverse engineering, ${ }^{255}$ or to extend trade secret protection beyond the time a secret is publicly disclosed. ${ }^{256}$ And while the issue has

251. See Application Group, Inc. v. Hunter Group, Inc., 72 Cal. Rptr. 2d 73, 88 (Cal. Ct. App. 1998). The court emphasized the strength of California's interest in voiding such agreeinents, particularly the policies in favor of free employee mobility. See id. at 89 . On the strength of California's interest, see also Hollingsworth Solderless Terminal Co. v. Turley, 622 F.2d 1324, 133839 (9th Cir. 1980) (concluding that California courts would not enforce covenants violative of section 16600 even if such covenants would be enforceable under the laws of the state cliosen by the contract itself); KGB, Inc. v. Giannoulas, 164 Cal. Rptr. 571, 578 (Cal. Ct. App. 1980); Frame v. Merrill, Lynch, Pierce, Fenner \& Smith Inc., 97 Cal. Rptr. 811 (Cal. Ct. App. 1971).

252. The Application Group court concluded that California's interests in precluding enforcement were "materially stronger" than Maryland's interests in allowing it. See 72 Cal. Rptr. 2d at 86.

253. See Dorr-Oliver, Inc. v. United States, 432 F.2d 447, 452 (Ct. Cl. 1970); Ingersoll-Rand Co. v. Ciavatta, 542 A.2d 879, 896 n.6 (N.J. 1988).

254. Of particular note is section 2870 of the California Labor Code, which provides that contracts may not require assignment of an "invention that the employee developed entirely on his or her own time without using the employer's equipment, supplies, facilities, or trade secret information" unless the invention relates to the employer's current or demonstrably anticipated business. CAL. LAB. CODE $\S 2870$ (Deering 1991). Other states have similar statutes. See MINN. STAT. ANN. $\S 181.78$ (West 1993); N.C. Gen. STAT. $\$ 66-57.1$ to 57.2 (1996); Wash. REv. Code ANN. $\$ 49.44 .140$ (WVest 1990).

255. See Acuson, Inc. v. Aloka, Inc., 257 Cal. Rptr. 368, 380 (Cal. Ct. App. 1989), ordered "depublished," 1989 Cal. S. Ct. Minutes 06 21. The state public policy interest in permitting reverse engineering in trade secret law admittedly may be tied to the Supreme Court's repeated threat that state trade secrets laws would be preempted if they precluded reverse engineering. See Bonito Boats, Inc. v. Thunder Craft Boats, Inc., 489 U.S. 141, 159-60 (1989); Kewanee Oil Co. v. Bicron Corp., 416 U.S. 470, 476 (1974).

256. Courts have taken imconsistent positions on whether the parties to a nondisclosure agreement may agree to require protection of a trade secret (and the payment of royalties) beyond the time the secret is disclosed and statutory protection is lost. Compare Warner-Lambert Pharm. Co. v. John J. Reynolds, Inc., 178 F. Supp. 655, 665-66 (S.D.N.Y. 1959) (holding a contraet to pay royalties enforceable even after secret has been disclosed), aff'd, 280 F.2d 197 (2d Cir. 1960), with RESTATEMENT (THIRD) of UNFAIR COMPETTTION $\$ 39 \mathrm{cmt}$ d, 41 cint. d (1993) (suggesting that 
not been litigated, I strongly suspect that trade secret policy will declare a widely distributed computer program like Windows to have lost trade secret protection at some point, despite efforts to characterize all of the hundred million or more sales as subject to nondisclosure agreennents. ${ }^{257}$ Contract terms ancillary to an unenforceable provision may also be struck down on public policy grounds. ${ }^{258}$

Fimally, states have public policy interests that coine from sources other than intellectual property law, but that may also place limits on Article $2 \mathrm{~B}$. For example, most states have antitrust statutes, ${ }^{259}$ and the application of those state antitrust laws will presuinably constrain the enforcement of contracts under Article 2B. Most states also consider the common law policy against restraints on alienation to be a bedrock principle of the law. ${ }^{260}$ Article $2 \mathrm{~B}$ represents a direct attack on this principle, both because it will validate "contract" terms that run with the information and because some of its provisions explicitly attach to the information even after transfer. ${ }^{261}$ There is a real conflict between this principle and Article 2B.

State intellectual property policies are entitled to just as much deference as any other state public policy, and perhaps as much as federal

public policy may render agreements purporting to protect information in the public domain unenforceable), Sarkes Tarzian, Inc. v. Audio Devices, Inc., 166 F. Supp. 250, 265-66 (S.D. Cal. 1958) (same), aff'd, 283 F.2d 695 (9th Cir. 1960), and Gary Van Zeeland Talent, Inc. v. Sandas, 267 N.W.2d 242 (Wis. 1978) (same). Cf. Pitney Bowes, Inc. v. Mestre, 701 F.2d 1365, 1371 (11th Cir. 1983) (holding that when a patent and related know-how are licensed together, the obligation to pay royalties on both expires when the patent does); St. Regis Paper Co. v. Royal Indus., 552 F.2d 309, 315 (9th Cir. 1979) (same).

257. See MERGES ET AL., supra note 43, at $855-56$ (noting that trade secret protection for a coinputer program can be destroyed by wide dissemination). Courts have disagreed over the extent to which widespread public sales compromise trade secrecy. Compare Data Gen. Corp. v. Grumman Sys. Support Corp., 825 F. Supp. 340, 359 (D. Mass. 1993) (holding that limited public distribution did not destroy secrecy), Manageinent Science Am., Inc. v. Cyborg Sys., Inc., 1977-1 Trade Cases I61,472 (N.D. Ill. 1977) (same), and Data Gen. Corp. v. Digital Computer Controls Inc., 297 A.2d 433, 436 (Del. 1971) (same), with Young Dental Mfg. Co. v. Q3 Special Prods., Inc., 891 F. Supp. 1345,1350 (E.D. Mo. 1995) (holding that publicly distributed software cannot be a trade secret) and Videotronics v. Bend Elecs., 564 F. Supp. 1471, 1476 (D. Nev. 1983) (same). Cf. Trandes Corp. v. Guy F. Atkinson Co., 996 F.2d 655, 663-64 (4th Cir. 1993) (finding that where software is publicly distributed, source code remains secret but object code does not).

258. For example, in Application Group, the court held that a contractual choice of law provision was "contrary to this state's fundamental policy" because it facilitated the enforccment of a contractual term deemed void under California law. Application Group, Inc. v. Hunter Group, Inc., 72 Cal. Rptr. 2d 73, 83 (Cal. Ct. App. 1998); accord Nedlloyd Lines B.V. v. Superior Court, 834 P.2d 1148 (Cal. 1992); Frame v. Merrill, Lynch, Pierce, Fenner \& Smith Inc., 97 Cal. Rptr. 811 (Cal. Ct. App. 1971).

259. See, e.g., Cal. Bus. \& Prof. Code $\$ 16700$ (West 1997); Tex. Bus. \& Com. Code AnN. $\S 15.10$ (West 1997).

260. See, e.g., John D. Park \& Sons Co. v. Hartman, 153 F. 24, 39 (6th Cir. 1907) ("The right of alienation is one of the essential incidents of a right of general property in movables, and restraints upon alienation have been generally regarded as obnoxious to public policy ....").

261. See, e.g., U.C.C. § 2B-507(b) (Draft, Aug. 1, 1998). 
policies. ${ }^{262}$ Certainly where the intellectual property right is created by the state itself, as in the case of trade secrets or the right of publicity, the state has a strong interest in defining the scope and limits of that right. State public policies that arise from intellectual property law should prevail in the face of Article 2B-endorsed contract terms to the contrary, just as analogous federal policies would. Whether they will do so is the subject of the next Section.

\section{The Interaction of Public Policy and Article $2 B$}

\section{Doctrinal Questions}

Article 2B acknowledges (as it must) that state contract law cannot override federal law. ${ }^{263}$ But preemption will not be the only federal limit on the enforcement of contracts in the Article $2 \mathrm{~B}$ world. To the extent that it applies, there is no question that the copyright misuse doctrine will prevail over anticompetitive terms-at least by precluding enforcement of the copyright in federal court, and perhaps by invalidating the term entirely. Indeed, the February Draft of Article 2B for the first time explicitly recognized copyright misuse doctrine as a potential limit on contract terms. ${ }^{264}$ Similarly, it seems clear that federal public policy will prevail over state contract law. Federal policy interests can invalidate contractual provisions $\mathrm{m}$ a wide variety of contexts, froin agreements to arbitrate Title VII ${ }^{265}$ einployment disputes ${ }^{266}$ to agreements to pay fact witnesses for their testimony. ${ }^{267}$ To hold that federal interests in intellectual property policy must be subordinated to state contract law would effectively set those interests at naught, in violation of the Supremacy Clause.

A more difficult question is presented by state public policy restrictions. Clearly there is no reason to expect that the public policies currently einbedded in contract law should be enforced in the Article $2 \mathrm{~B}$ world. Because these policies are creatures of contract law, a new contract law can change them. Thus, should the drafters of Article 2B choose to abolish such contract law protections (as they have done in

262. While Jerry Reichman and Jonathan Franklin suggest that a doctrine of "public interest unconscionability" be added to Article 2B, Reichman \& Franklin, supra note 8, at 30-32, such a concept is perhaps better located in state intellectual property policy itself, rather than in contract law.

263. See U.C.C. $\$ 2$ B-105(a) (Draft, Aug. 1, 1998).

264. See U.C.C. \& 2B-105, reporter's note 3 (Draft, Feb. 1998); see also U.C.C. \$ 2B-105, reporter's note 2 (Draft, Aug. 1, 1998) (recognizing copyright misuse as a potential limit on contract terms).

265. 42 U.S.C. $\$ 2000 \mathrm{e}(1998)$.

266. See Rosenberg v. Merrill Lynch, Pierce, Fenner \& Smith Inc., No. 96-12267-NG1998 U.S. Dist. LEXIS 877, at *65-66 (D. Mass. Jan. 26, 1998).

267. See Goldstein v. Exxon Research \& Eng'g. Co., No. 95-2410, 1997 U.S. Dist. LEXIS 14600, at *11 (D.N.J. Feb. 28, 1997). 
allowing vendors to effectively eliminate all warranties in most contracts), ${ }^{268}$ and should state legislatures choose to enact such a new rule, there is no barrier to their doing so.

The same may not be true, however, of public policies embedded in state intellectual property laws. As a general rule, state contract law is subject not only to its internal constraints, but also to public policies that come from other state law sources, including statutes and judicial decisions. ${ }^{269}$ State courts will refuse to enforce contracts that violate such noncontractual public policy rules. For example, a contract to murder someone-or a contract to pay for "legal" services rendered by someone who is not a nember of the bar-may be perfectly valid as a matter of contract law, but courts will still refuse to enforce them. ${ }^{270}$ Contractual freedom is subject not only to the dictates of state law, but also to the requirements of other applicable state and federal laws. ${ }^{271}$

Judicial refusal to enforce contract terms because of conflicting state policy should not depend on whether the contract statute was enacted before or after other state laws. State legislatures are not obliged to reenact all their laws of general applicability every time they change contract law. ${ }^{272}$ Put another way, one should not assume that enactment of Article 2B works an implied repeal of preexisting public policy rules. The more logical approach is to require the legislature to repudiate existing law unambiguously if it really wishes to change it. Article $2 B$ should therefore not be read to repudiate generally applicable principles of state intellectual property law without clear guidance from the legislatures.

The August Draft discusses its interaction with other state laws in some detail. ${ }^{273}$ Section $2 \mathrm{~B}-105$ (d) provides that conflicting state statutes and regulations prevail over Article $2 \mathrm{~B}$ in cases in which the state law "establish[es] a consumer protection." Wh4 What a "consuiner protection" is in this context is ambiguous; one might construe any number of state rules that restrict the scope of trade secrets as "consumer protections," for example.

268. Sections $2 B-406$ and $2 B-401$ (d) of Article $2 B$ together permit vendors to disclaim all express and implied warranties simply by including appropriate language in a shrinkwrap license or other form contract. See U.C.C. \$§ 2B-401(d), 2B-406 (Draft, Aug. 1, 1998).

269. See American Home Assurance Co. v. Stephens, 130 F.3d 123, 126 (5th Cir. 1997).

270. See, e.g., Birbrowcr, Montalbano, Condon \& Frank, P.C. v. Superior Court, 949 P.2d 1 (Cal. 1998) (holding that contract requiring payment for services that constituted unauthorized practice of law was void as contrary to public policy).

271. See Fisher, supra note 171 (cataloguing public policy restrictions on freedom of contract).

272. Article $2 B$ seems both to acknowledge this and to dispute it, providing that some state statutes (but presumably not others) in force at the time the final draft is enacted will continue to apply. See U.C.C. § 2B-105(d) (Draft, Aug. 1, 1998). State laws enacted after Article 2B, of course, would be free to modify it.

273. See id. § 2B-105.

274. Id. § 2B-105(d). 
In addition, the August Draft provides that "principles of law and equity supplement this article," and in particular that trade secret laws and unfair competition laws are "not displaced" by Article 2B. ${ }^{275}$ This language is encouraging, because it suggests in an open-ended way that existing rules of law and equity, as well as the "fundamental public policy" grudgingly included in section $105(\mathrm{~b}),{ }^{276}$ all survive the enactment of Article 2B. The fact that these equitable rules "supplement" rather than supersede the provisions of Article $2 \mathrm{~B}$ nonetheless calls for some searching judicial inquiry imto the relationship between these various areas of law. It would seem just as unreasonable to supersede judicial expressions of public policy impliedly as it would to directly supersede statutory rules. After all, both statutes and the common law reflect public policy concerns that arise outside of contract law. Indeed, overriding state policy with Article $2 \mathrm{~B}$ might be worse for common law public policy rules than for statutes. Statutes can be reenacted, but a body of common law decisions cannot easily be recreated by a legislature. It is also worth noting that prior provisions of the U.C.C. have left many such common law doctrines intact. ${ }^{277}$

\section{Normative Questions}

To be sure, not everyone is happy with the idea that public policy overrides contract. Judge Easterbrook has suggested that it should do so only rarely, ${ }^{278}$ and advocates of a strong form of private ordering often suggest that "the market" will do a better job of determining public policy than "the law."279 Robert Gomulkiewicz derides this effort to balance between policy and freedom of contract as "over-regulating" by the government. ${ }^{280}$ But in fact, intellectual property is a prime example of an area in which we cannot simply rely on "the agreement of the parties" to choose our public policy. This is true partially because intellectual property licenses are notoriously fallible as indicators of the "intent" of the parties; ${ }^{281}$ as we proceed to remove all trace of assent

275. Id. $\$ 2 \mathrm{~B}-105$ (c).

276. Id. § 2B-105(b).

277 See, e.g., Edward L. Rubin, The Code, the Consumer, and the Institutional Structure of the Common Law, 75 WASH. U. LQ. 11, 13-14 (1997) ("The entire framework of the U.C.C. is based on common law.").

278. See Cange v. Stotler \& Co., Inc., 826 F.2d 581, 596 (7th Cir. 1987) (stating that "[c]ontracts rarely defeat the function of a statute so utterly that they may be set aside" as violative of public policy).

279. See Bell, supra note 11, at 591; Hardy, supra note 11, at 218-19.

280. Gomulkiewicz, supra note 4, at 3.

281. See Lemley, Economics of Improvement, supra note 10, at 1042-72 (explaining in detail the problems with the assumption of efficient intellectual property licensing). 
from the notion of contract, ${ }^{282}$ the philosophical basis for private ordering disappears as well. ${ }^{283}$

But the problem is more fundamental than this. Intellectual property is a deliberate, government-sponsored departure from the principles of free competition, designed to subsidize creators and therefore to induce more creation. ${ }^{284}$ This departure from the competitive model affects third parties who are not participants im the contract. ${ }^{285}$ If 1 agree not to criticize, parody, reverse engineer, improve, adapt, or extend your work, I am not the only one who pays the price for that agreement. All those consumers who would have bought my new product lose value as well, and that value simply isn't accounted for in the deal between the parties. ${ }^{286}$ It can't be, because I myself would not be able to capture the full social surplus from those people who would buy my improved product. ${ }^{287}$ This potential surplus is accounted for by the constraints and dictates of intellectual property law-it is the very reason intellectual property provides only a limited incentive and not complete control. ${ }^{288}$ Those intellectual property rules may not always be pretty, or easy to

282. See U.C.C. $\S \S 2 B-207,2 B-208$ (Draft, Aug. 1, 1998); Hill v. Gateway 2000, Ine., 105 F.3d $1147,1148-49$ (7th Cir. 1997), cert. denied, 118 S. Ct. 47 (1997).

283. Even if one is convinced that contract terms to which two parties agreed necessarily reflect the optimal allocation of resources between them, the same assumption cannot be made in a case like Hill, in which the "terms" to which the parties supposedly agreed were not even availabIe to one of the parties at the time the contract was inade. See Hill, 105 F.3d at 1199.

284. See Lemley, Economics of Improvement, supra note I0, at 993-1000 and sources cited therein. Indeed, if intellectual property rights did not allow copyright and patent owners to price above inargimal cost, they would have failed in their essential purpose. See Allan N. Litman, Monopoly, Competition and Other Factors in Determining Patent Infringement Damages, 38 IDEA 1, 11 (1997) (acknowledging that using the term "Inonopoly" to describe intellectual property rights is currently in disfavor, but arguing that "[a] patent does grant a legal monopoly over the making, using and selling of the patented article or inethod. To deny that is to tilt at windinills.").

At the very least, Julie Cohen is surely correct to note that we don't have sufficient information across the range of creative works to conclude definitively that they exhibit a high degrce of substitutability in spite of intellectual property law. See Cohen, supra note 11, at 60 .

285. For elaboration on the third party effects, see Cohen, supra note 11; Wendy J. Gordon, On the Economics of Copyright, Restitution, and "Fair Use": Systemic Versus Case-by-Case Responses to Market Failure, 8 J.L. \& INFo. ScI. 7 (1997); Lemley, Economics of Improvement, supra note 10, at 1057-58; Loren, supra note 168, at 48-56; McGowan, supra note 145; Jonathan Dowell, Comment, Bytes and Pieces: Fragmented Copies, Licensing, and Fair Use in a Digital World, 86 CALIF. L. Rev. 843, 864-76 (1998).

286. See ANDreas A Papandreou, Externality AND INSTItUTIONS 225 (1994) ("[]]nstitutional change does not require efficiency gains to be initiated, it requires gains to the initiators of ehange, which may or may not coincide with an overall increase in wealth...."); $c f$. Wendy J. Gordon, Asymmetric Market Failure and Prisoner's Dilemma in Intellectual Property, 17 U. DAYTON L. REV. 853, 857 (1992) (arguing that intellectual property protection cannot be justified if users will face narket failure).

287. Julie Cohen inakes this poimt as well. See Cohen, supra note 1I, at 86-87. For a similar argument made in terms of political theory, see Philip E. Agre, Mixed Metaphors: Inscribing Social Visions in Networked Computers (1997) (unpublished manuscript, on file with author) (suggesting that "externalities" are in fact central rather than peripheral in an information economy).

288. See Lessig, supra note 38 , at 638 . 
determine, and they certainly aren't perfect descriptions of an optimal incentive structure. ${ }^{289}$ But they are at least an effort to arrive at the right balance of incentives-an effort that would never even be made were we to leave social ordering entirely in the hands of private parties. ${ }^{200}$

\section{CONCLUSION}

Article 2B may well usher in a brave new world in which the predominant protection provided to intellectual property owners is based on contract rights, not on property rules. ${ }^{291}$ But that new world will not be entirely free from the constraints of intellectual property policy. Contract terms that flagrantly conflict with federal law, or that upset the balance struck by that law, may be preempted. Even if they are not, a wide variety of state and federal public policy rules, including the doctrines of patent and copyright misuse, will limit the enforceability of contract terins that threaten federal policy.

It is worth noting that most (though by no means all) of the examples of federal policy interests I have discussed involve limits on the ability of intellectual property owners to expand protection, not limits on the ability of licensees to defeat protection. That is, most of the policy interests reflect ceilings rather than floors on the scope of protection. This is no accident. Intellectual property has always reflected a rough effort to balance the incentives of creators against the needs of particular consumers, improvers, and the public. ${ }^{292}$ Historically, this has generally meant that the law must protect creators against the vagaries of the market; the most obvious threat to the balance came from rampant piracy, not excessive control over copyrighted works. But as Article 2B expands those intellectual property owners' power to obtain through contract law everything that intellectual property would give them and more, the role of intellectual property law must necessarily shift. Instead of being primarily a creator protection statute, intellectual property will

289. On some of the flaws with the process, see Jessica Litman, Copyright Legislation and Technological Change, 68 OR. L. REv. 275 (1989); Jessica D. Litman, Copyright, Compromise, and Legislative History, 72 CORNELl L. REv. 857 (1987).

290. See Cohen, supra note 11 ; Lemley, Economics of Improvement, supra note 10 , at 1083 ; McGowan, supra note 145 , at 56.

It is worth noting that even advocates of default rules as a norm endorse immutable rules when "unregulated contracting would be socially deleterious because parties internal or external to the contract cannot adequately protect theinselves." Ayres \& Gertner, supra note 23, at 88; see also Robert C. Ellickson, Property in Land, 102 YALE LJ. 1315, 1367 (1993) (“[G]roup-imposed restraints on alienation are defensible when they bar a transfer that would harm others more than it benefits the parties to the transaction.").

291. A number of scholars have inade this argument. See Bell, supra note 11, at 612; ElkinKoren, Contracts in Cyberspace, supra note 11; Fisher, supra note 171.

292. See supra note 34 . 
become more and more a consumer protection law. And if Article 2B is enacted, consumers will certainly need one. 